\author{
UNIVERSITY OF CALIFORNIA \\ COLLEGE OF AGRICULTURE \\ AGRICULTURAL EXPERIMENT STATION \\ BERKELEY, CALIFORNIA
}

\title{
RANGE GRASSES OF CALIFORNIA
}

ARTHUR W. SAMPSON AND AGNES CHASE

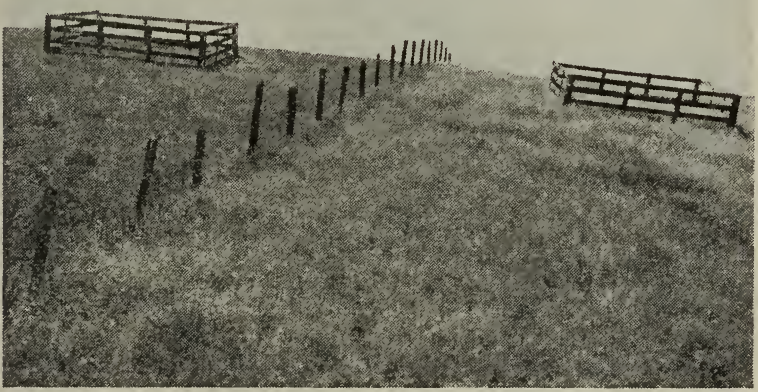

RANGE IMPROVEMENT STUDIES

\section{BULLETIN 430}

September, 1927 


\section{PREFACE}

To apply the best methods of range management, the stockman must be able to judge the condition of the range for himself. To do this he must know the principal forage plants, their period of life, and their requirements as to reproduction. The illustrated keys, brief descriptions, and pictures of the plants should assist him in this.

The purpose of this bulletin is (1) to familiarize stockmen with the more important grasses of the State and show where they grow, and (2) to point out their forage value and the conditions under which the different kinds reproduce under grazing. This is a necessary preliminary to the development of state-wide range reseeding methods now under investigation.

In the preparation of this paper the authors have made use of the valuable collections and data in the grass herbarium of the United States Department of Agriculture. Several of the illustrations were lent by the Department.

The Authors. 


\title{
RANGE GRASSES OF CALIFORNIA
}

\author{
ARTHUR W. SAMPSON ${ }^{1}$ and AGNES CHASE ${ }^{2}$
}

\section{"PURE-BRED" RANGE FORAGE}

The acreage of grazing lands in California is several times greater than that upon which cultivated crops of all kinds are grown, and its efficiency is high because a fairly good balance exists between the forage crop of the summer and of the winter range.

The great importance of heading the range herd and flock with pure-bred sires is undoubted, but effort in this direction is all but wasted unless an ample supply of "pure-bred feed" or more properly nutritious, palatable, and abundant forage is available. It is astonishing what poor returns livestock give, regardless of breed or quality, when maintained on "scrub range acres."

Unfortunately a large proportion of the ranges are more or less seriously depleted. Among the measures planned for the improvement of the grazing grounds of California are those concerned with the re-establishment of a better forage cover. Two methods are open, (1) bringing back the better naturally occurring range plants by favoring seed production and (2), seeding with suitable cultivated or introduced forage plants.

The systems of natural reseeding known as deferred and as rotation grazing offer expedient and practical means of revegetation. Good results from deferred grazing may be expected on any range of grasses or other herbs, for it concerns a system of grazing which provides for the development and planting of seed of all species, thereby renewing the waning range forage. Rotation grazing provides for a system of grazing of certain natural types or subdivisions of a range in which the animals are not permitted on the lands the season through, but the grazing is rotated according to a definite plan. The life history studies here reported point the way to the most efficient use of the deferred and rotation grazing systems.

${ }^{1}$ Associate Professor of Forestry, University of California, and Plant Ecologist in the Experiment Station.

${ }^{2}$ Associate Agrostologist, Bureau of Plant Industry, U. S. Department of Agriculture, Washington, D. C. 
Investigations conducted in various parts of the West have shown that range improvement by seeding with cultivated forage plants is limited essentially to moist meadows and fertile soils where the annual

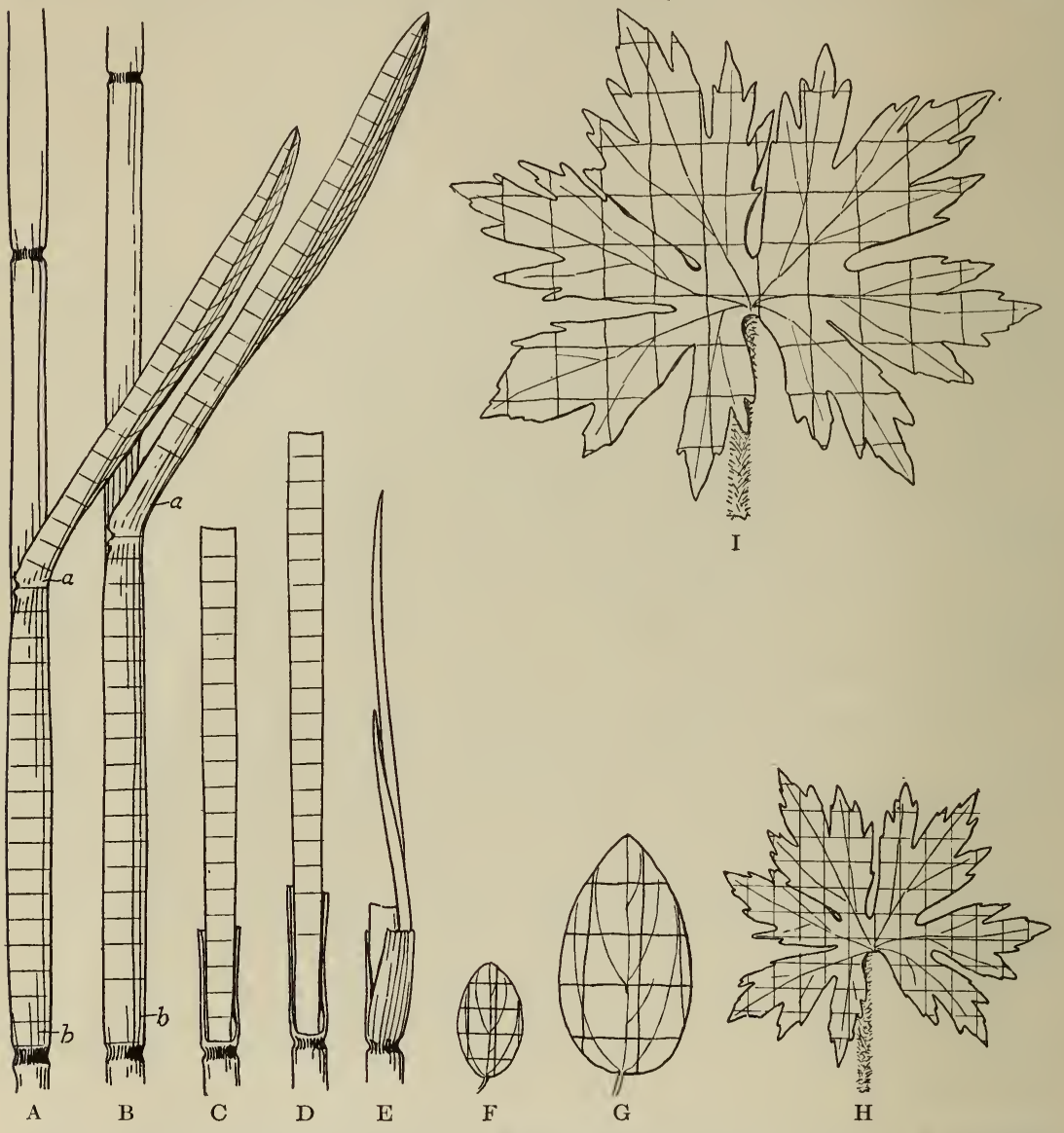

Fig. 1.-Leaves of grass and of broad-leaved plants marked to show areas of growth. A, Grass leaf: $a$, base of blade; b, base of sheath. B, Same leaf one week later. showing growth at a and b. C, Base of culm in sheath; bud of potential branch shown at right. D, Same culm one week later, showing growth at the very base. E, Base of joint (sheath and culm) of a grazed culm, showing development of branch bud into a leafy stalk. F-G, Leaf of bluebrush, at one week interval, showing uniformity of growth throughout the entire surface. H-I, Leaf of geranium at one week interval, showing uniformity of growth throughout the area, similar to that of the bluebrush leaf.

precipitation is comparatively heavy. ${ }^{3}$ Natural reseeding, on the other hand, once the requirements of growth and reproduction are known, is applicable everywhere.

California is a state of varied elevations and of many climates, of many different geological formations and soils, of varying amounts of

${ }^{3}$ Sampson, Arthur W. Range and pasture management. pp. 40-58. figs. 1-130. John Wiley \& Sons, New York. 1923. 
precipitation and degrees of aridity. No one kind of forage plant, therefore, occurs over the entire State, but each species is more or less confined to a particular life zone, for example, wild oats on the winter or foothill ranges. Before practical methods of natural revegetation can be recommended, the period of growth, the time of seed maturity, the period of rest, indeed the entire life cycle of the important forage plants of each grazing zone must be ascertained. ${ }^{4}$

Studies for this purpose are now being made on the winter or foothill ranges, for these lands are much in need of reseeding.

The most important plants on the range are the grasses. They are not necessarily more palatable or nutritious than are many broadleaved plants, like bur clover or bluebrush, but everything considered they are of first rank as pasture feed. Grasses are comparatively stable in the amount of forage which they produce year after year; they are nutritious, palatable, and wholesome, never causing bloat; the leafage cures well on the roots, and hence is valuable as food for livestock the year through. Perennial grasses are generally late in the succession or ecological development, hence they tend strongly to stabilize the yield. Moreover, grasses withstand close and repeated grazing better than most plants. The growing region of the leaf is at two points, at the base of the blade (fig. 1-B,a) and the base of the sheath, (fig. 1-B,b). Growth is not arrested, therefore, though the greater part of the growing blade is nipped off. The main stalk (culm) when grazed is necessarily destroyed but the potential branch in the axil of the upper remaining sheath (fig. 1-C) then develops and becomes the leafy flower stalk (fig. 1-E). In the leaves of bluebrush (fig. 1-F,G), Mertensia, Geranium (fig. 1-H,I), and the like, on the other hand, the growth is uniform throughout the leaf area, so that when the upper part of leaves of plants of this kind is devoured no further appreciable development of the leaf is possible. Leaves without a stem (petiole) such as those of false dandelion and foxglove, grow from the base like those of grasses, hence such plants withstand close, repeated grazing comparatively well.

\section{THE LIFE AND HOME OF THE PLANT}

The native cover is everywhere composed of the kinds of plants which have fought for their lives and won because they were the best able to adjust themselves to the conditions under which they lived. Under natural conditions certain rigid laws determine the character of the earth's clothing.

${ }^{4}$ Sampson, Arthur W. Native American forage plants. pp.1-435. figs.1-199. John Wiley \& Sons, New York. 1924. 
Every plant produces far more seed than can find place to sprout and grow. There is a continuous struggle among plants for foothold and food. In every place capable of supporting plant life, from bare rocks, seashore, or swamp, to rich forest lands, the struggle goes on, and those plants win that can best endure hard conditions or make the most of favorable ones. But while plants are governed by the environment they in turn work changes in it. These changes, slight but continuous, above and below the surface of the ground, react upon the plants, which must repeatedly adjust themselves or give way to other kinds better fitted to the changed conditions.

Every Plant Has its Day.-Vegetation and climate-wind, rain, snow, and ice-work together making soil out of bare rock. Different stages of the work are carried on by different kinds of plants. Only certain forms of plant life can grow on soils in the making. When these pioneer plants, together with the climate, have produced a layer of soil they are crowded out of their homestead by more highly specialized forms. These invaders add a little humus to the scant soil and are in turn crowded out by other forms. Thus each set of plants paves the way for its own destruction, until a permanent cover is formed, the climax vegetation for the locality.

Succession and Stabilization.-This development of vegetation is called plant succession. It refers to the successive series of relatively distinct plant types in a given habitat, each dominant for a time, then giving way to the next series. Five typical stages are represented diagrammatically in figure 2 . On the bare rock the windborne spores of lichens adhere and germinate. Any surface of bare rock, unless very recently exposed, will show little grayish-green patches of lichens. The lichens corrode the surface of the rock, grains of dust and spores of mosses catch in the uneven surface of the lichen or around its edges. The mosses develop and catch more dust and hold water from rain and snow. The tiny cracks produced by the rootlets of the lichens and mosses fill with water which freezes and enlarges the crack. Thus little by little the surface of the rock is broken up into grains, and its salts made available for plant growth, until a covering of soil is formed and held by this first or pioneer stage (fig. 2, A).

Seeds of all kinds are blown about by thousands and fall by chance in all habitats, but all perish save the relatively few that fall in a spot that meets their requirements. Seeds of shallow-rooted annual flowering plants find the scant soil developed by the pioneer type sufficient for their needs. The plants of the first stage give way as these annuals increase and form the second or transitional stage (fig. 2, B). This type, by adding humus to the soil, makes it more retentive of water, 


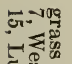

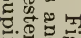

5

कह

证

5ึ.

밀.

$\infty$

สะกำ

is

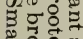

=요

두유

익 9

o

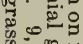

.

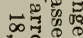

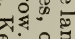

9

르응

प्रे

둥

.

5

s.

웅

\%

క

ㄴ.

5

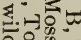

品

¿

웡

돌

:.

영

密

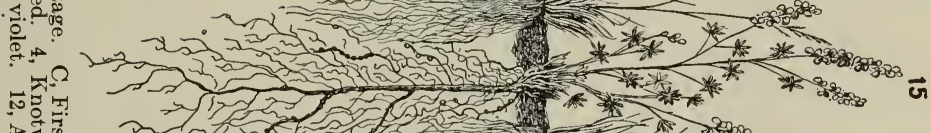

品势

유용

wor of

पs?

记

$5 \rightarrow 4$

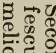

व.

包。

曲造

50

है․․

承吗
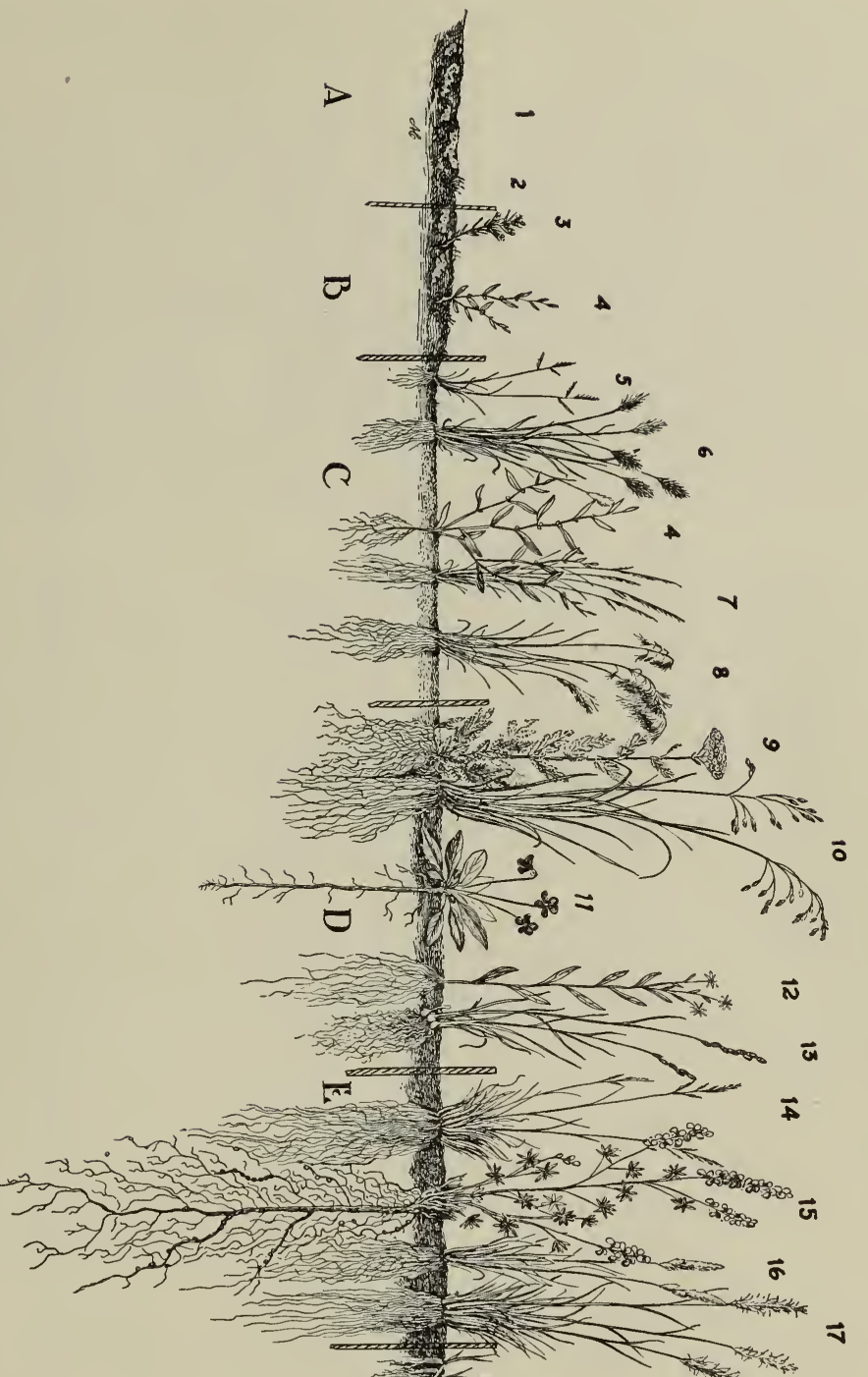

$\vec{v}$

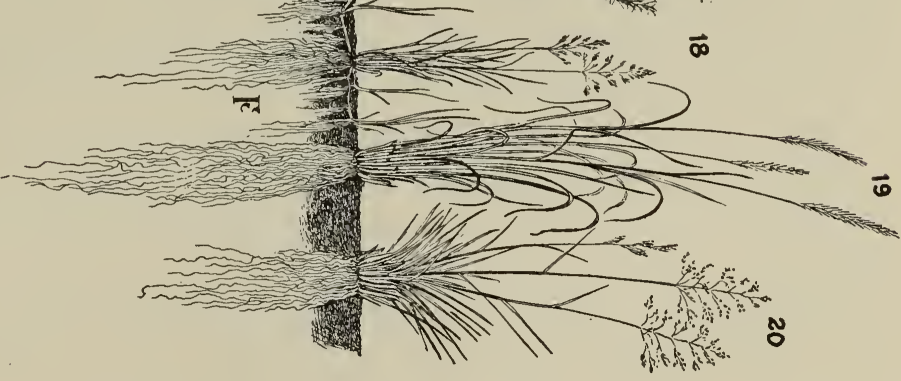


and in turn gives way before the deeper-rooted plants which form the first herb stage (fig. 2, C).

As the formation of soil and humus continues, its rate of progress depending on climatic conditions and the luxuriance of plant growth, the plants of the first herb stage are replaced by a cover of perennial broad-leaved herbs and a few short-lived perennial grasses, which form the second herb stage (fig. 2, D). This cover is soon invaded by various bunch grasses and passes into the mixed grass-and-herb stage (fig. 2, E).

By this time the soil is well decomposed and capable of retaining a moisture supply available to vegetation sufficient to support the highest and most stable type of which it is capable. The perennial grasses and other plants of the last or climax stage, therefore, soon take possession (fig. 2, F).

Plant Succession and Range Management.-The ideal type for foraging animals is that of the mixed grass-and-herb stage, with a large proportion of plants of the climax type. For cattle and horses a pure grass range is satisfactory, but for sheep an admixture of broad-leaved herbs is preferable. Moreover, where the forage is fully but conservatively utilized each season, the mixed grass-and-herb stage is the highest type that can be maintained indefinitely. This type usually produces fatter lambs than any other. The pioneer and the transitional stages are worthless for grazing. The vegetation of the first herb stage sometimes furnishes a small amount of inferior forage early in the season. However, the soil supporting this type is but loosely held by the vegetation and grazing, by destroying the plant cover, may lead to serious erosion, and thus retard the succession of the better forage types.

Every effort should be made to maintain the range in a high successional stage such as a perennial grass cover or a grass-and-herb stage. This can be done only by avoiding overgrazing and providing for the development of an occasional seed crop. Until recently overgrazing was not recognized in its early stages but had to be judged by the more or less complete wiping out of one or more of the higher, productive plant types. Now small departures in the grazing capacity of the range are recognized by the replacement of the palatable plants of the higher stages by inferior short-lived species, those capable of occupying soils packed hard by excessive trampling and close grazing. ${ }^{5}$

The successional stages to which the different kinds of grasses belong are given, in so far as they are known, in the discussion of the different species.

${ }^{5}$ Sampson, Arthur W. Plant succession in relation to range management. U. S. Dept. Agr. Bul. 791:1-76. fig. 1-26. 1919. 


\section{THE CHARACTERS OF TRUE GRASSES}

Grasses are herbs with fibrous roots and jointed stems (culms), hollow (rarely pithy), except at the nodes, which are solid (fig. 3). The culms may be simple (not branching),

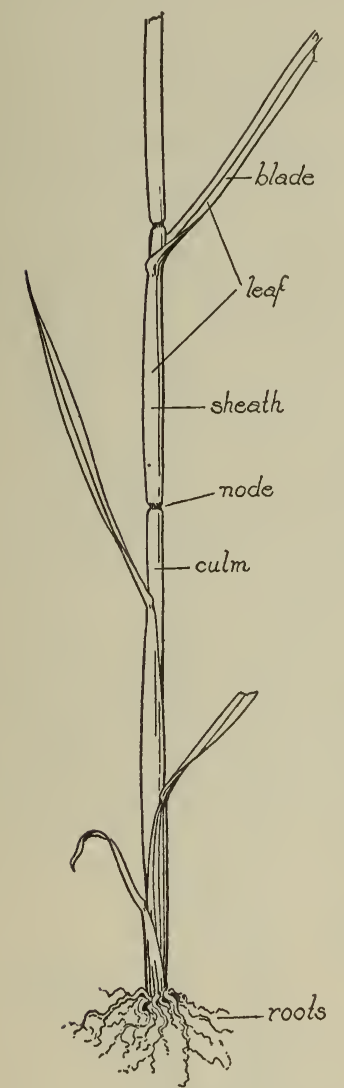

Fig. 3.-Simple culm with roots and leaves. though there is a potential branch at every node, and, if the main culm is cut off as in grazing, one of the latent branches will develop. Or the culms may bear branches at one or all the nodes. The branching habit is fairly uniform for any given species, and commonly for a whole genus.

Leaves.-The leaves are borne one at each node, always in two ranks. They are parallelveined and composed of two parts, the sheath, which surrounds the culm like a split tube, and the blade, which is usually strap shaped. At the junction of the sheath and blade, on the inside, is a small appendage, the ligule (fig. 4), consisting of a thin membrane or a ring of hairs. These characters are peculiar to the grass family, and plants not having them are not true grasses. Clovers and other forage plants are, therefore, not grasses. Sedges, some of which are

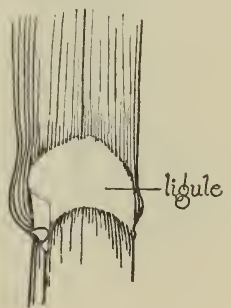

Fig. 4.-Ligule. commonly called slough grasses, resemble grasses, but their stems are solid and their leaves are in three ranks. Some rushes resemble grasses but their stems are not jointed; their flowers are in form like very minute lilies, borne in large or small heads, not in two ranks in spikelets, as in grasses.

\section{Flowers and Seed}

Flowers.-The flowers of grasses are very small and are reduced to the essential organs, a single ovary with two styles (one in corn), bearing feathery stigmas; and three stamens (rarely 1 or 6 ). The ovary contains an ovule which when fertilized develops into the seed; the stamen consists of a two-celled anther borne on a long filament. The cells of the anther contain innumerable pollen grains. At flowering 
time the cells split and the minute pollen grains are scattered by the wind. Those that fall on the sticky stigmas of flowers of the same kind of grass germinate and form a minute tube which pushes down through the style and carries their contents to the ovule, fertilizing it. Each of these tiny flowers is borne in the axil of a small green bract (the

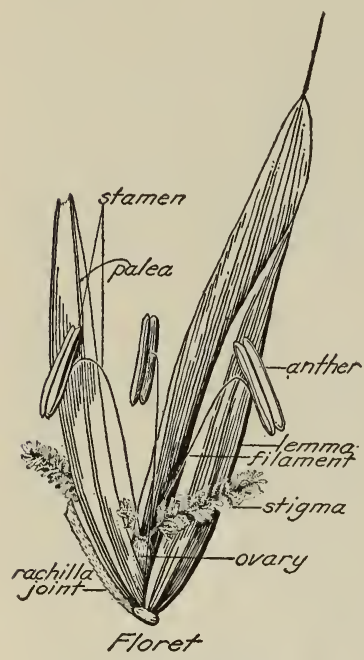

Fig. 5.-Floret.

lemma) and is enveloped in a smaller inner bract (the palea). The flower with its lemma and palea is termed the floret (fig. 5). The hull on a grain of barley, wheat or oats, and the hard shell-like covering of a grain of millet consists of lemma and palea. The florets, like the leaves, are borne in two ranks upon a little axis (the rachilla). Below the florets are two bracts without flowers (the glumes). The glumes, rachilla and florets together, are called the spikelet (fig. 6). The spikelet is a miniature leafy branchlet, with sessile (stemless) flowers in the axil of all but the lower pair of leaves, the glumes and lemmas being altered or specialized leaves.

Spike or Panicle.-In oat grasses, brome grasses, and blue grasses the spikelets are on pedicles (little stems) on the branches of a panicle (fig. 7). In some grasses, timothy and the millets, for example, the panicle branches, and the pedicels are so short that the head looks like a spike. In

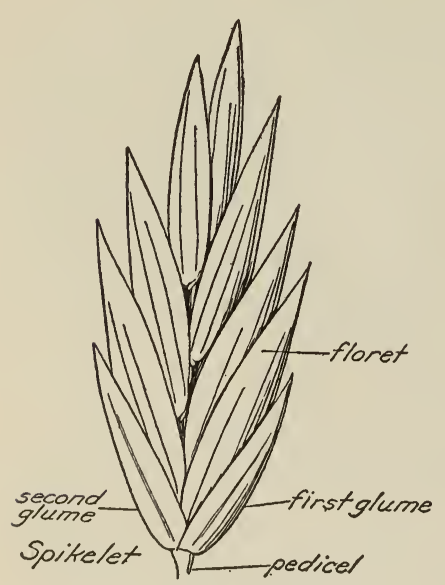

Fig. 6.-Spikelet.

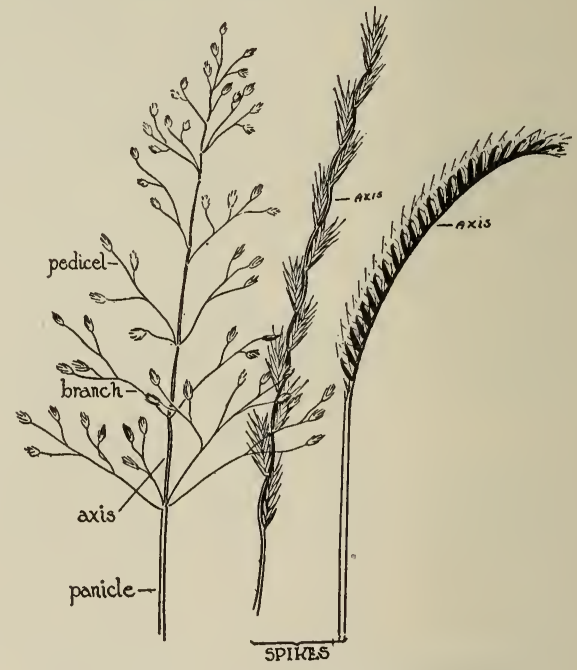

Fig. 7.-Forms of flowering head (inflorescence). 
wheat, barley, rye, and their wild relatives, the wheat grasses, wild barleys, and wild ryes, the spikelets are sessile (without a stem) on opposite sides of a simple axis, but at different nodes, forming a spike.

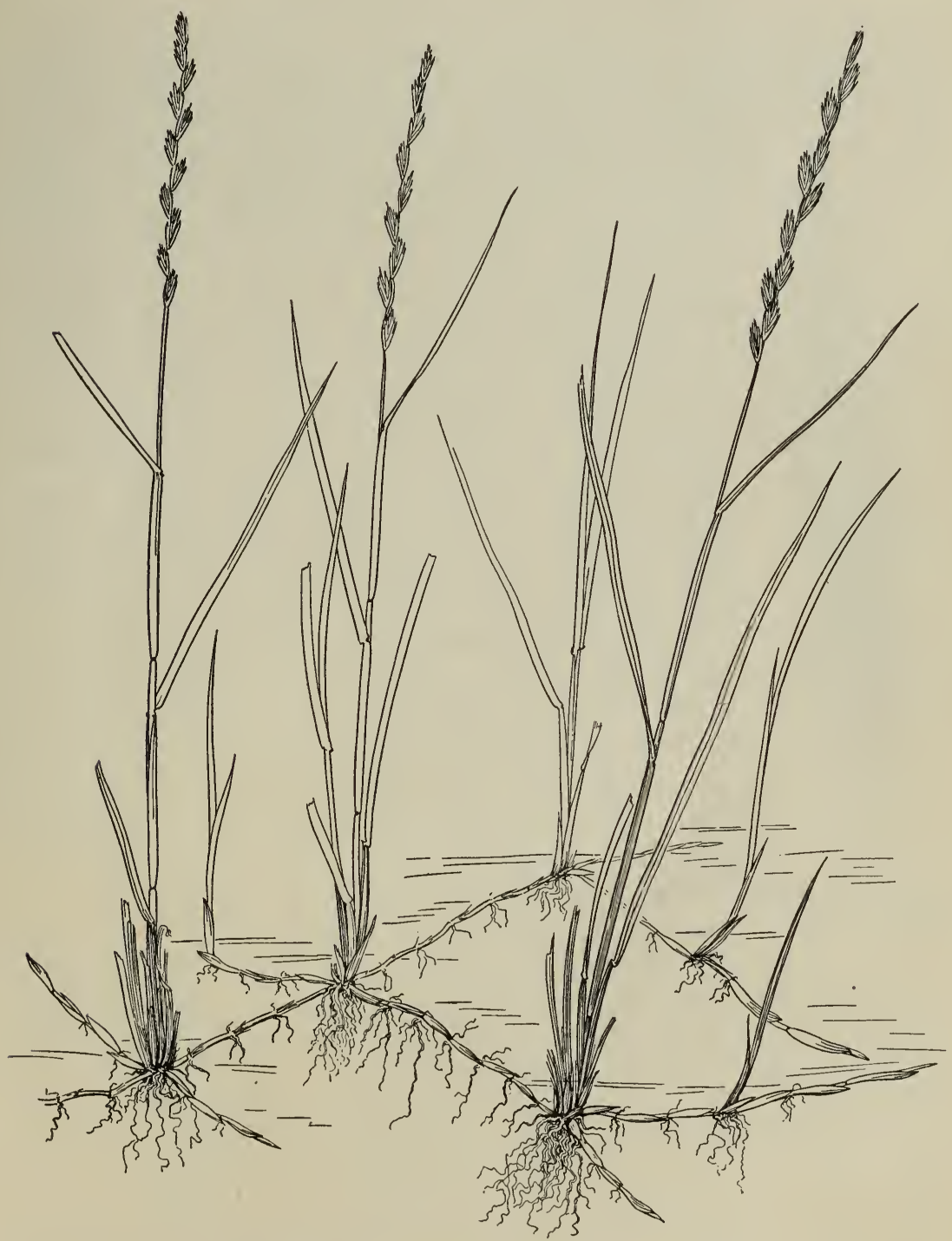

Fig. 8.-Sod-forming grass showing mode of propagation.

In grama grasses the spikelets are also sessile but close together on one side of an axis, forming one-sided spikes and these are borne, few to several, on a simple main axis. 


\section{Vegetative Parts of the Grasses}

Length of Life and Vegetative Reproduction.-Grasses may be annuals, - - germinating, seeding, and dying in a single season, - as in the brome grasses; or perennials, the individual plants living from

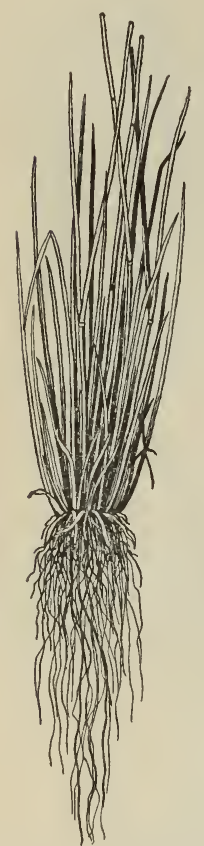

F Fig. 9.-Bunch grass showing c row ded stems and roots. two to several years and seeding year after year. Perennial grasses, besides producing seed, increase vegetatively. Shoots are formed at the basal nodes and live over the winter. If these shoots grow up inside the sheaths of the parent stems, a bunch grass, such as fescue, is formed. If the shoots push through the sheath and run along the surface of the soil, a mat is formed as in Bermuda grass. If the shoots run underground a tough sod is formed as in Kentucky blue grass and the sod-forming wheat grasses. These modified stems (rootstocks) are jointed and bear scales (which are reduced leaves). Roots develop from the lower side of the nodes and leafy shoots from the upper. These underground shoots develop into new plants which send out new rootstocks. In this way a dense network of rootstocks is formed below ground, new plants develop continually and replace the old ones that die and form a permanent sod (fig. 8). For this reason grasses of this type withstand grazing and trampling better than bunch grasses (fig. 9). In bunch grasses the tuft enlarges year by year as new shoots are produced from the lower nodes of each culm, two or more being sent forth each year (fig. 10). The dense tufts of foliage of Idaho fescue and similar grasses are composed of the young leafy shoots that, the following year, are to bear the seed stalks. In very densely tufted

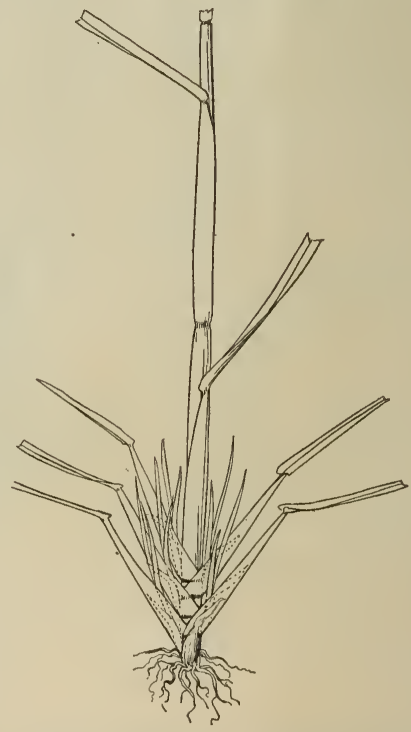

Fig. 10.-Diagram of vegetative reproduction of a bunch grass, showing a culm of 1926 with leafy shoots at the lower nodes (sheaths spread to show shoots), the shoots living over winter and forming flowering culms of 1927. grasses, however, only a few of these shoots actually flower. 


\section{Value to MaN}

Grasses, of all plants, are the most important to man, and especially to the stockman. Not only do they supply the principal bread stuffs of the world-wheat, rye, barley, Indian corn, oats, rice, sorghum, and millet-but also, by providing a large part of the forage of grazing animals, they supply us, secondarily, with beef, mutton, lamb, wool, leather, dairy products, and horsepower. 


\section{KEY TO TRIBES AND GENERA}

One uses a key by reading contrasting paragraphs, $1 \mathrm{a}$ and $1 \mathrm{~b}, 2 \mathrm{a}$ and $2 \mathrm{~b}$, etc. (b always indicating the second alternative), and choosing the one with which the grass in hand agrees. (The few genera and species that might reasonably be referred to either paragraph are looked for under both). After following the key until it leads to a name the grass is compared with the description on the page indicated, the characters of the tribe, genus and species, given in the keys, being kept in mind. A figure of a typical spikelet is presented for each genus in the key, the spikelet number corresponding with the number of the genus. Illustrations do not show proportional magnifications.

1a. Spikelets on pedicles in open or contracted panicles (Fig. 7, p. 10).

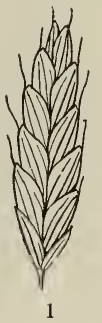

2a. Spikelets with 2 to many florets.

3a. Glumes shorter than the lowest florets; (see also Koeleria, p. 53) Tribe FestuCEAE (p. 20).

4a. Spikelets $1 / 2^{-1}$ in. (12-24 mm.) long; lemmas awned or awn-tipped from a minutely 2-toothed apex; (see also Melica aristata)........1. Bromus (p. 20).

4b. Spikelets mostly less than $1 / 2$ in. (10-12 $\mathrm{mm}$.) long (if longer, culms with bulblike base).

5a. Spikelets $1 / 4$ to nearly $1 / 2$ in. $(6-10 \mathrm{~mm}$.) long (less in Melica imperfecta), blades not having boat-shaped tip.

6a. Plants not forming sod; florets rounded on the back.

7a. Glumes not papery; upper florets like the others.

2. Festuca (p. 29).

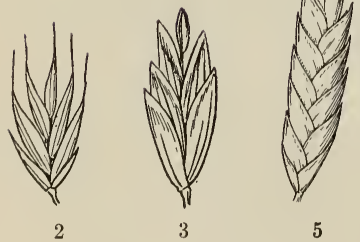

7b. Glumes papery; upper florets reduced to a club-shaped rudiment.

3. Melica (p. 36).

6b. Plants forming a tough sod; florets keeled on the back.

5. Distichlis (p. 48).

5b. Spikelets not over $1 / 4$ in. ( $6 \mathrm{~mm}$.) long, or if so, blades having boat-shaped tip.

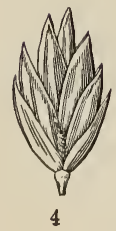

8a. Lemmas 5-7 nerved.

9a. Panicles not conspicuously drooping; lemmas somewhat pointed, the nerves not prominent, coming together at the tip.... 

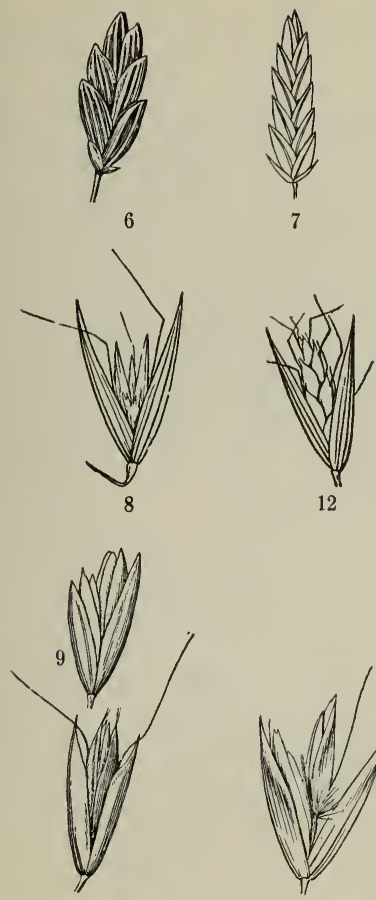

10
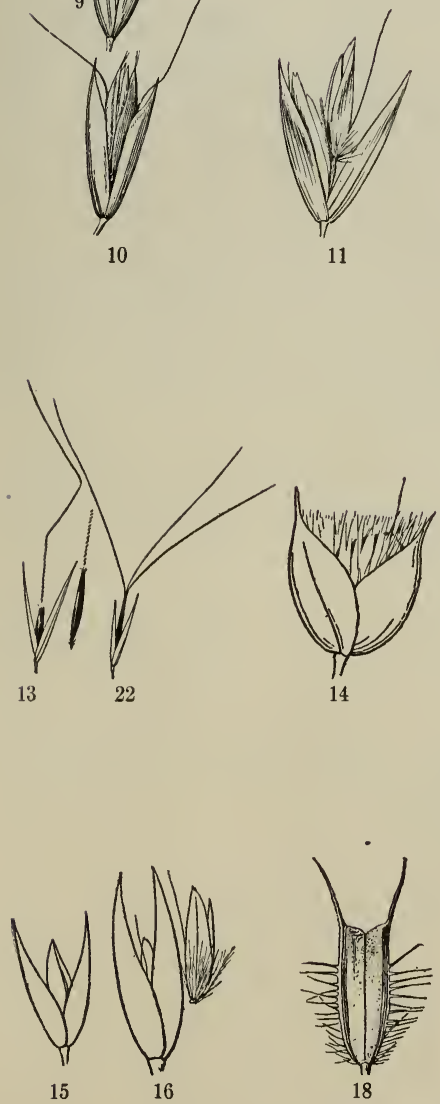

9b. Panicles conspicuously drooping; lemmas blunt, the nerves prominent, parallel.

6. Panicularia (p. 49).

8b. Lemmas 3-nerved

7. Eragrostis (p. 50).

3b. Glumes as long, mostly longer than the lowest florets. (Tribe Aveneae, p. 51). 10a. Spikelets over $1 / 2$ in. (12 mm.) long.

11a. Florets 2 or 3 ; panicle large, nodding. 8. Avena (p. 51).

11b. Florets several; panicle small, erect. 12. Danthonia (p. 56). 10b. Spikelets not over $1 / 4$ in. (6 mm.) long. 12a. Lemmas awnless..9. Koeleria (p. 53). 12b. Lemmas awned.

13a. Lemmas keeled, 2-toothed at the summit, awn arising from above the middle....10. Trisetum (p. 54).

13b. Lemmas rounded on the back, jagged at the summit, awned from below the middle...11. Aira (p.54).

2b. Spikelets with 1 perfect floret.

14a. Spikelets all alike; glumes not firmer in texture than the lemmas. Tribe AgrosTIDEAE (p. 57).

15a. Florets ("seed") firm at maturity, awned at summit, sharp-pointed at base.

16a. Awn simple (not divided) a distinct line between the awn and body of the lemma.

17a. Awn 1-3 in. (24-70 mm.) long, persistent

13. Stipa (p. 57).

17b. Awn about $1 / 4$ in. (6 mm.) long, falling off.....14. Oryzopsis (p. 62).

16b. Awn 3-divided, no line between the awn and body of the lemma

22. Aristida (p. 77).

15b. Florets ("seed") not hardened, not sharp-pointed at base.

18a. Glumes longer than the floret.

19a. Spikelets V-shaped or nearly so.

20a. Florets naked or nearly so at the base.

15. Agrostis (p. 64).

20b. Florets with a tuft of soft hairs at the base.

16. Calamagrostis (p. 67).

19b. Spikelets 2-horned, from the abrupt points of glumes; panicles dense, spike-like........18. Phleum (p. 71). 

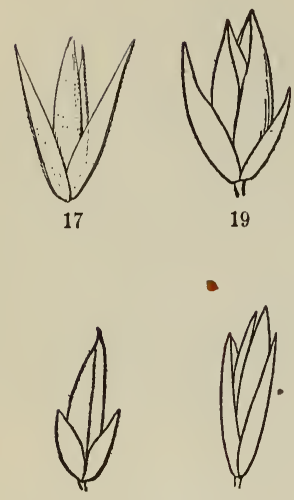

20

21

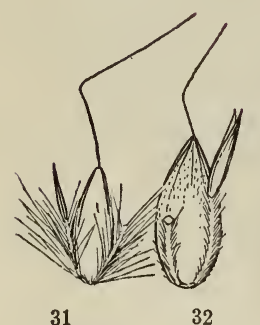

31

32

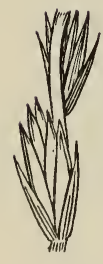

23

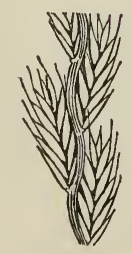

25

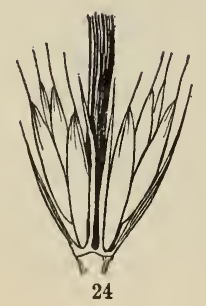

18b. Glumes shorter than the floret (if nearly as long the spikelet falling entire).

21a. Spikelets falling entire, that is, the glumes not remaining.

17. Cinna (p. 71).

21b. Spikelets not falling entire, the florets falling at maturity leaving the glumes on the pedicel.

22a. Lemmas 1-nerved, awnless; panicles as broad as long.

19. Sporobolus (p. 72).

22b. Lemmas 3-nerved; panicles narrow, or if broad, the lemmas long-awned.

23a. Plants mostly less than $1 \mathrm{ft}$. (30 cm.) tall

20. Muhlenbergia (p. 74).

23b. Plants $2-5 \mathrm{ft} .(60-150 \mathrm{~cm}$.) tall.......21. Epicampes (p. 76).

14b. Spikelets of two kinds in pairs, one sessile and perfect, the other pediceled and sterile; glumes firmer than the floret. Tribe Andropogoneae (p. 89).

24a. Panicle soft, silky, the spikelet partly hidden in long hairs of joints

31. Andropogon (p. 90).

24b. Panicle not silky, spikelets not hidden.

32. Holcus (p. 90).

1b. Spikelets sessile on the axis (Fig. 7, p. 10) forming spikes.

25a. Spikelets not falling from the axis entire, the florets falling from the glumes or the axis disjointing with spikelets attached (falling entire in Beckmannia with numerous spikes).

26a. Spikelets large, on opposite sides of the axis; spike single. Tribe Hordeae (p. 78).

27a. Axis of spike not breaking up, the florets falling from the glumes at maturity.

28a. Spikelets single at each node of the axis.

29a. Spikelets placed flatwise to the axis; both glumes present.

23. Agropyron (p. 79).

29b. Spikelets placed edgewise to the axis; first glume wanting.

25. Lolium (p. 84).

$28 \mathrm{~b}$. Spikelets $2-4$ at the nodes.

24. Elymus (p. 82). 


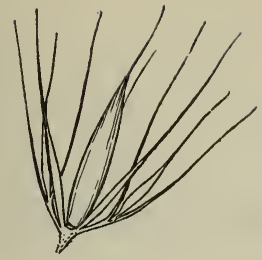

26

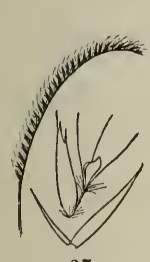

27

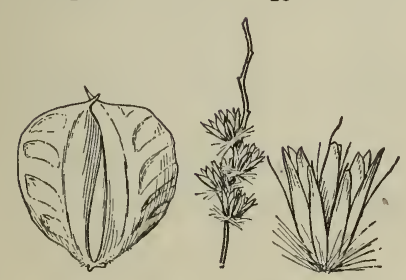

29

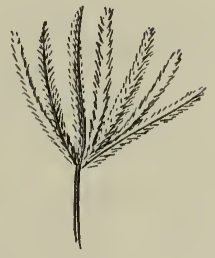

28

30 27b. Axis of spike breaking up at maturity with a spikelet attached to each joint; spikes bristly.

26. Hordeum (p. 85).

26b. Spikelets small, on one side of the axis (Fig. 7), forming small 1-sided spikes, the spikes several to many.

30a. Spikes few to several, spikelets not circular.

31a. Spikes spaced along the axis.

27. Bouteloua (p. 86).

31b. Spikes clustered at the summit like sticks of a fan......28. Chloris (p. 87).

30b. Spikes numerous along a main axis; spikelets nearly circular.

29. Beckmannia (p. 88).

25b. Spikelets in clusters of 3 on opposite sides of the axis, the clusters falling entire from the axis.

30. Hilaria (p. 89). 


\section{OUTLINE OF GRASS TRIBES}

Showing type of spikelet characteristic of each, and diagram of head (inflorescence).
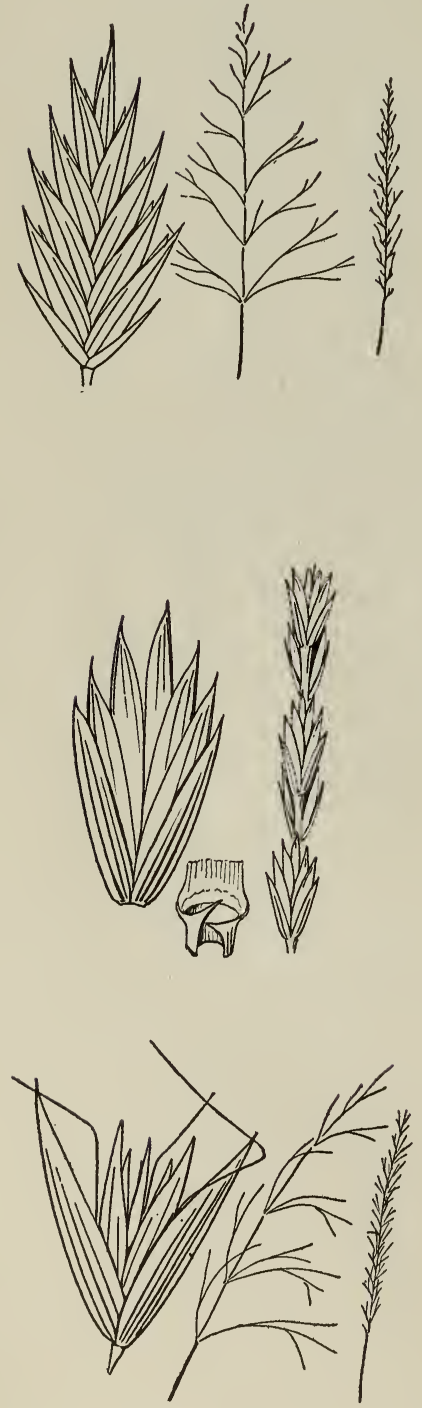

A. FESCUE TRIBE (FESTUCEAE)

Spikelets few to several flowered, laterally compressed.

Florets falling from the glumes.

Glumes relatively small.

Lemmas awned from the tip or just below it.

Inflorescence an open or narrow panicle.

(Brome grasses, fescues, melic grasses, blue grasses, etc.)

B. BARLEY TRIBE (HORDEAE)

Spikelets 1- to many - fløwered, sessile on opposite sides of a jointed rachis, forming a spike.

Rachis rather than spikelets specialized.

Inflorescence a solitary spike.

(Wheat and wheat grasses, barley and barley grasses, rye and rye grasses, etc.)

\section{OAT TRIBE (AVENEAE)}

Like Fescue tribe but glumes enlarged and florets fewer in number.

Lemmas awned from the back (not developed in Koeleria).

(Wild oats, June grass, trisetums, hair grasses, etc.) 


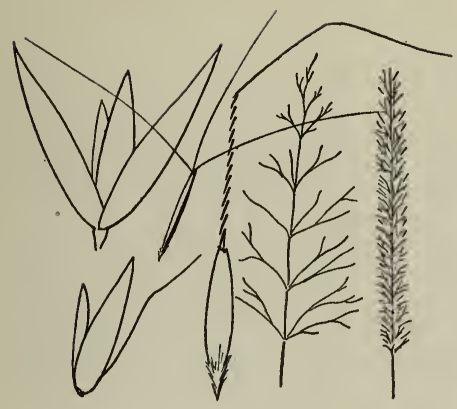

D. TIMOTHY TRIBE (AGROSTIDEAE)

Like Festuceae reduced to its lowest terms; spikelets, 1-flowered.

Lemmas awnless or awned, the awn from back or summit.

Inflorescence an open or narrow panicle.

(Needle grasses, redtops, reed grasses, timothy, etc.)

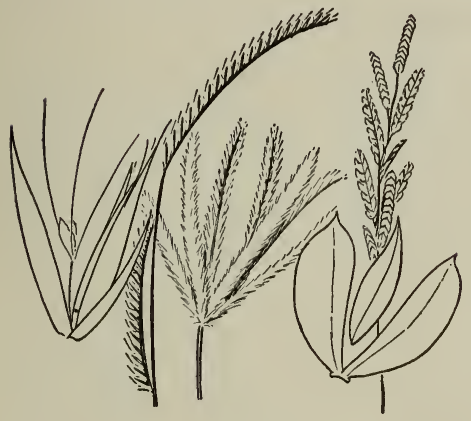

\section{E. GRAMA TRIBE (CHLORIDEAE)}

Spikelets 1-few flowered, sessile on one side of the rachis.

All but the lowest floret commonly sterile and variously modified.

Inflorescence of 2 to many 1-sided spikes, spaced along a main axis or clustered at its summit.

(Grama grasses, chloris grass, Beckmann grass.)

\section{F. CURLY MESQUITE TRIBE (NAZIEAE)}

Spikelets 3 together, one perfect and two staminate, sessile and appressed to the axis, forming a spike, the three falling together, attached to each other.

\section{G. SORGHUM TRIBE}

(ANDROPOGONEAE)

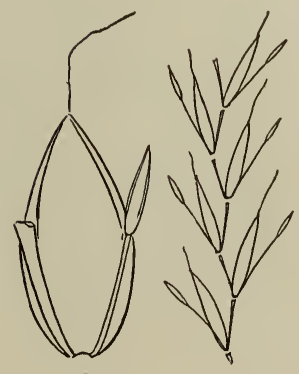

Spikelets paired, one perfect and sessile, the other sterile and pedicellate, borne on a jointed rachis.

Fertile spikelets with one perfect terminal floret and a sterile lemma below; falling with joints of rachis and sterile pediceled spikelet attached.

Glumes hardened, inclosing the florets.

(Johnson grass, plume grass.) 


\section{FESCUE-BLUE GRASS-BROME GRASS TRIBE (FESTUCEAE)}

This tribe, which embraces the all-important fescues, blue grasses, and brome grasses, includes the best range plants in the state. The outstanding characters of the tribe are: Spikelets several to manyflowered, pediceled in open or narrow panicles; florets falling from the glumes at maturity; culms simple.

\section{BROME GRASSES (BROMUS)}

Twenty-two brome grasses are found in the state, of which 13 are annuals and 9 are perennials. The annuals are valuable as food for livestock especially on the winter ranges where they often grow most abundantly, but the most of them must be pastured before the seed matures. A few produce an abundance of forage of fair quality. Some are troublesome invaders, and at maturity are often injurious to stock. The perennial species grow over a wider elevational range than the annuals and are most abundant in the yellow pine type or transition zone. They are mostly of rank growth and hence are not always fully utilized by sheep. Most of the annual species invade the ranges in the early stages of depletion but they give way somewhat readily to- perennial vegetation. The perennial bromes make their appearance comparatively early in the establishment of a perennial plant cover, usually preceding the blue grasses, fescues, and needle grasses. ${ }^{7}$ For effective revegetation all brome grasses, because of their large, light seeds, require the trampling of grazing animals to bury the seed and insure germination.

The domesticated hay and pasture plant called Hungarian or Sмоoтh Brome Grass (Bromus inermis) is known to most stockmen. The most valuable native species are: Large-flowered brome grass, rescue brome grass, narrow-flowered brome grass, and soft cheat. Several closely related species are considered in the discussion of these. Three annuals are injurious to range livestock.

Description of Brome Grasses. - The bromes are relatively coarse grasses growing in small clumps, short-lived perennials or annuals; blades relatively wide and soft; spikelets larger than those of any other genus, the lemmas awned; the seed is large, thin and chaffy; in the three injurious annuals it is sharp-pointed at the base.

${ }^{7}$ Sampson, Arthur W. Plant succession in relation to range management. U. S. Dept. Agr. Bul. 791:28, 33. 1919. 


\section{KEY TO SPECIES}

1a. Plants perennial (or B. unioloides a winter annual).

2a. Spikelets flattened, the florets keeled.

3a. Florets distinctly awned.

1. B. carinatus.

3b. Florets pointed or awn-tipped only

2. B. unioloides.

2 b. Spikelets not flattened, the florets rounded on the back.

3. B. vulgaris.

1b. Plants annual.

4a. Spikelets and florets oval; seeds blunt at base...................4. B. hordeaceus.

4b. Spikelets V-shaped; florets long and narrow; seeds sharp-pointed. Injurious bromes

(Class II. p. 27)

\section{Perennial Brome Grasses}

1. Large-flowered brome grass (Bromus carinatus) is $2-31 / 2 \mathrm{ft}$. (60-100 cm.) tall, with stout culms, abundant rather velvety foliage, the blades flat and rough margined, and usually large open panicles, the

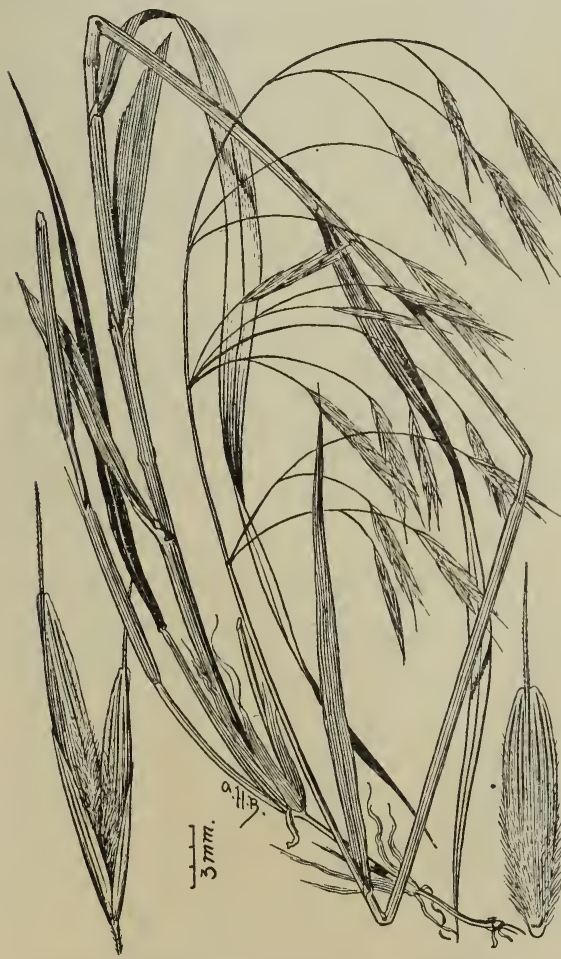

Fig. 11.-Large-flowered brome grass (Bromus carinatus). large purplish spikelets borne toward the ends of the long spreading branches. Dwarfed plants commonly have narrow panicles. (Fig. 11).

Distribution and Habitat.This is most abundant on the Pacific slope, where it occurs between elevations of about 2,000 to 10,000 feet. At higher elevations the plants are often only $1 \mathrm{ft}$. tall. The species thrives best in the yellow pine type or on lands of like elevation. Except in small areas where it is the dominant grass, the stand is scattered. The most common habitats are open woodland, grassy hillsides where the soil is good, and well-drained parks.

Forage Value and Reproduction.-The herbage of the largeflowered brome grass is highly relished by livestock. Horses and cattle devour a fair portion 
of the flower stalks when they are succulent, but sheep graze the herbage closely only when green. The large seed heads are relished by all foraging animals, for they normally contain much nutritious grain. A luxuriant second-growth of herbage is available in the autumn where the area is grazed once early in the season. This is the choicest of feed and forms excellent grazing for sheep, being especially valuable before marketing the lambs. The seed begins to ripen early in July in the lower elevations and by late August it has been cast in the more elevated types. Reproduction is good under favorable pasture conditions.

LARGE MOUNTAIN BROME GRASS (Bromus marginatus) is very similar to large-flowered brome-grass, but has smooth sheaths and spikelets with shorter awns. This species grows in habitats similar to those of large-flowered brome grass, but occurs also in the mountains of the state east of the Sierra range. In forage value and reproduction it is practically identical with large-flowered brome grass.

NarRow-LeAF brome grass (Bromus subvelutinus) is shorter and rather stiff, the foliage downy but rough to the touch, the blades narrower and with inrolled margins; panicles narrow, upright.

Distribution and Habitat.-This grass is found in the foothills and low mountains between elevations of about $3,000-7,500$ feet. In abundance it is similar to that of large-flowered brome grass, but is more strictly confined to the yellow-pine type of lands or those of similar elevation. The best stands occur on moderately dry wooded hills, well drained parks, and meadows.

Forage Value and Reproduction.-Narrow-leaf brome grass is grazed closely by cattle, horses, and sheep. The leafage is mostly basal. The seed heads, when well filled, are eagerly sought by cattle and horses. The seed matures early in July, an abundance of seed being produced in favorable seasons. Under wise grazing this species may be expected to increase appreciably in abundance.

2. Rescue brome grass (Bromus unioloides) is a short-lived perennial or winter annual, $2-31 / 2 \mathrm{ft}$. $(60-100 \mathrm{~cm}$.) tall, with long rough blades and a large drooping panicle (small and narrow in dwarfed plants) of grayish green spikelets. (Fig. 12).

Distribution and Habitat.-Rescue brome grass is introduced, probably from the Andes, and is confined to the southern half of California. It is a plant of the foothills, occurring from sea-level to an elevation of about 3,500 feet. The best growth is on rich, light soils of medium moisture. Under such conditions growth is rapid and luxuriant.

Forage Value and Reproduction.-Wherever rescue brome grass grows well it is highly esteemed both for pasture and hay. In Texas and elsewhere in the South attempts have been made to extend its range 


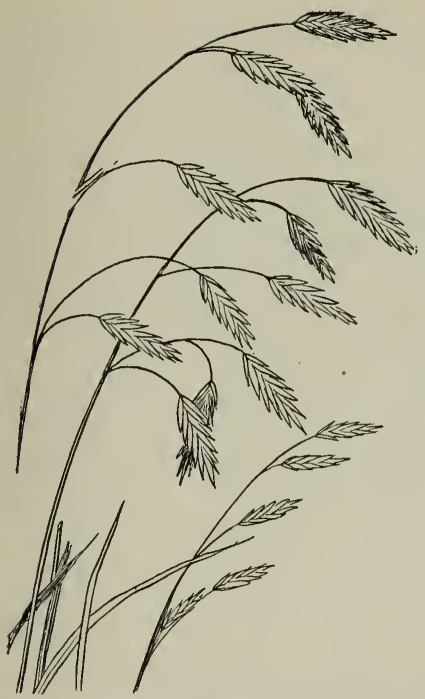

Fig. 12.-Rescue brome grass (Bromus unioloides).

by seeding, but this has been only partly successful. All classes of stock are fond of the leafage and seed heads, especially where the winter growth is good. The seed ripens in May and June, a large seed crop being produced under favorable conditions. The plant is normally a winter annual, but if it is grazed before seeding it lives for several seasons, producing a large amount of herbage. It is not improbable that the range of rescue brome grass may be extended appreciably in southern California by seeding. The seed should be scattered before the autumn rains begin.

\section{Narrow-flowered brome grass}

(Bromus vulgaris) is $2 \frac{1}{2}-4 \mathrm{ft}$. $(75-120$ cm.) tall, rather slender with sparselydowny foliage and somewhat narrow nodding panicles of long narrow spikelets. (Fig. 13).

Distribution and Habitat.-This species occurs throughout the state from sea level to about 7,000 feet; accordingly it is of value as stock food both on the winter and the summer ranges. The largest herbage production, however, is at intermediate elevations, where it is sometimes the dominant species, though pure stands are seldom seen even under the best conditions. It is moderately tolerant of shade but grows commonly, also, on exposed hillsides and moderately moist flats.

Forage Value and Reproduction.-The large proportion of rather fine soft leaves, as compared with the culms, is characteristic of narrow-flowered brome grass and the relish with which they are consumed by all classes of livestock gives the plant high rank as forage. In palatability and the amount of forage produced it is second only to large-flowered brome grass. A valuable aftermath is produced where the lands are grazed early in the season. The seed habits are fairly strong and

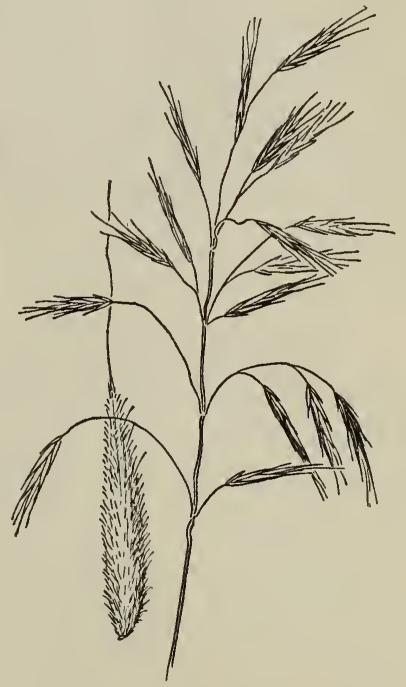

Fig. 13.-Narrow-flowered brome grass (Bromus vulgaris). 
reproduction is rapid under favorable conditions. The seed crop begins to ripen early in June on the lowest elevations, as in Marin County, and by August 1 it has ripened and dropped in the more elevated lands.

WoOdLAND BRome GRASS (Bromus laevipes) is not so tall as narrowflowered brome grass and has a longer, more drooping panicle. TALL BROME Grass (B. grandis) stouter and as much as $5 \mathrm{ft}$. tall; and OrcutT BROME GRASS ( $B$. orcuttianus), with stiff culms and the foliage crowded at the base, are closely related to narrow-flowered brome grass. They occur from sea level in the Coast Range, to elevations typical of the yellow pine type, known as the transition zone. They grow in association with large-flowered and with narrow-flowered brome grasses but are less abundant. In forage value and in the methods of procuring revegetation, they are similar to the associated brome grasses named.

SUKSDORF BROME GRASS (Bromus suksdorfii), (also closely related to narrow-flowered brome grass) with smooth foliage and narrow, rather dense panicles, is chiefly a mountain grass occurring between elevations of about 5,000 and 10,000 feet. It occupies rough wooded areas and exposed slopes, a large proportion of which are not readily accessible to stock. While the leafage is palatable to grazing animals, the plant grows so sparsely over the greater part of the range as to yield but a small amount of herbage.

\section{Annual Brome Grasses}

The annual brome grasses considered from a forage viewpoint are of two classes, (1) those which are grazed with impunity regardless of the season, and (2) those which are objectionable on the range at some stage of their growth, by causing mechanical injury to animals.

\section{Class I}

4. Soft cheat or chess (Bromus hordeaceus) stools freely, and forms dense tufts $10-30 \mathrm{in} .(25-75 \mathrm{~cm}$.) tall, with velvety foliage and a rather dense oblong panicle of soft minutely downy spikelets. Dwarfed plants do not stool but may produce seed when only 5 or 6 in. (12 to $15 \mathrm{~cm}$.) tall. (Fig. 14).

Distribution and Habitat.- Soft cheat is a native of southern Europe. It is found throughout the state but is most abundant in the coastal region. The elevational range is from sea level to about 4,000 feet. It inhabits inferior clay loam and sandy soils that are well drained. Overgrazing and heavy packing of the soil usually favor the invasion of this grass. 


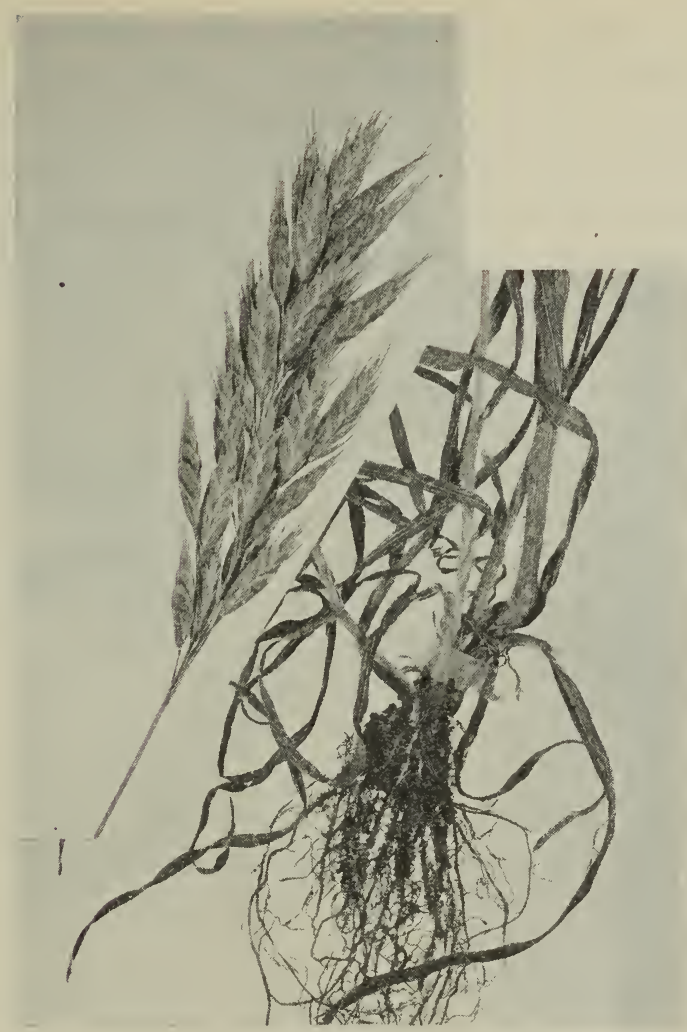

Fig. 14.-Soft_cheat or chess (Bromus hordeaceus).

Forage Value and Reproduction.-In some localities soft cheat is cut for hay. As a pasture plant it is the best of the annual brome grasses, and early in the season the leafage is grazed with moderate relish by all classes of livestock. The yield of hay of mature stands is sometimes three-fourths of a ton to the acre. In some localities it has taken possession of depleted range lands.

"Since the forage of soft cheat is produced exceptionally early, it is of special value at that season, and the leaf blades are then eagerly eaten. There is diversity of opinion among stockmen as to the nutritive qualities of this grass. Many claim that it is a valuable feed when supplemented with other species of grasses and weeds, but owing to its 'washy,' succulent nature in the spring of the year, it is not conducive to putting on solid fat. Miners say that their pack animals fatten quickly upon it when left at leisure, but when grazing upon it exclusively they are unable to work without excessive loss of flesh. After the seeds have ripened the plant is of very little forage value." 8

${ }^{8}$ Sampson, Arthur W. Important forage plants, their life history and forage value. U. S. Dept. Agr. Bul. 545:25. 1917. 
The seed crop ripens in May and June, a large amount having strong germinating power being produced.

Cheat (Bromus secalinus) is taller than soft cheat, with smooth sheaths, and a more open, drooping panicle, and smooth plump spikelets.

Distribution and Habitat.- It is an introduction from Europe and is something of a weed on the range and in cultivated fields.

Forage Value and Reproduction.-It is a plant of the foothills, mostly in the northern half of the state. During the winter and until about March 15 the herbage furnishes a large amount of forage of fair quality for all grazing animals. Later the leafage dries up, the numerous culms become fibrous and unpalatable, and the stand is distinctly inferior in every way. Often cheat grows so dense as to exclude such valuable plants as alfilaria, bur clover, and the better grasses. An unusually large amount of seed is produced which, because of its early maturity (it is usually scattered by May 15), tends to maintain the density of the cover against all but perennial species.

In some localities the belief prevails that cheat is a degenerate, scrubby wheat, its characters being derived from the presence of alkali rising to the soil's surface. Others contend that this "inferior wheat" is the result of the deterioration of the original high-yielding cultivated strain. It is a distinct species and is no more variable than other species of brome grasses.

DOWNY-SHEATHED BROME GRASS (Bromus commutatus), closely resembling cheat, but with downy culms and less plump spikelets, is a somewhat common, rather "stemmy" plant which produces only a small amount of leafage. It occupies mostly inferior soils in the lower foothills.

The forage value of this species is not nearly equal to that of soft cheat, both because grazing animals are not so fond of it and because the yield is small. The seed matures in May and June.

RATTLESNAKE BROME GRASS (Bromus brizaeformis) differs from the others in having awnless spikelets $3 / 4^{-1}$ in. (18-25 mm.) long, with broad inflated florets. These large drooping spikelets rattle against each other at maturity, hence the common name. Rattlesnake brome grass is an introduction from Europe. It is a plant of the foothills, where it is often associated with cheat grass. It grows sparsely, however, over the greater part of the range. The forage is grazed with moderate relish early in the season, until the seeds are fairly well formed. In palatability the herbage is similar to that of cheat grass. It is essentially a winter annual, that is, the seed germinates in the autumn and growth continues through the winter. The seed matures in June. 


\section{Class II}

Red brome grass, needle brome grass, and June brome grass have long-awned florets which cause mechanical injury to livestock, in rare instances causing death.

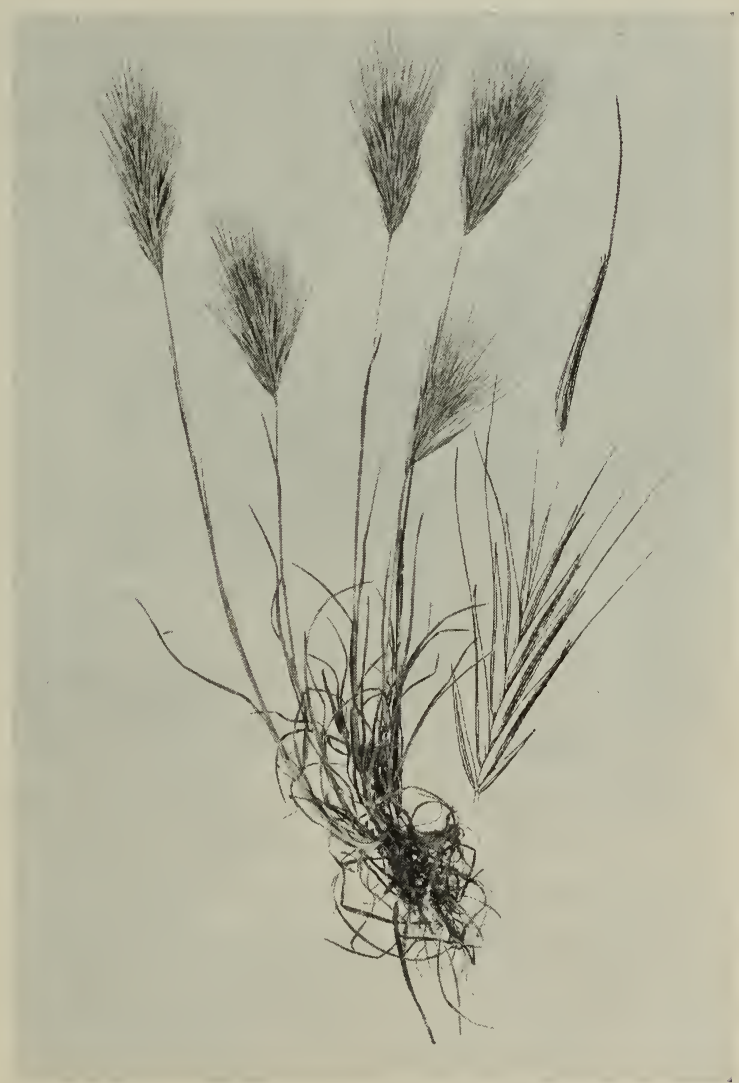

Fig. 15.--Red brome grass (Bromus rubens).

RED BROME GRASS (Bromus rubens), sometimes called "broncho" brome grass, grows from $6-15$ in. (15-38 cm.) tall, in small tufts, with scant foliage and dense bristly reddish panicles, somewhat resembling heads of barley. It is a native of southern Europe. (Fig. 15). 
Needle BROMe GRASS (Bromus rigidus), known also as "ripgut" and "devilgrass," is taller, sometimes $2 \mathrm{ft}$. (60 cm.) in height, with drooping looser panicles of long-awned spikelets, the floret with its

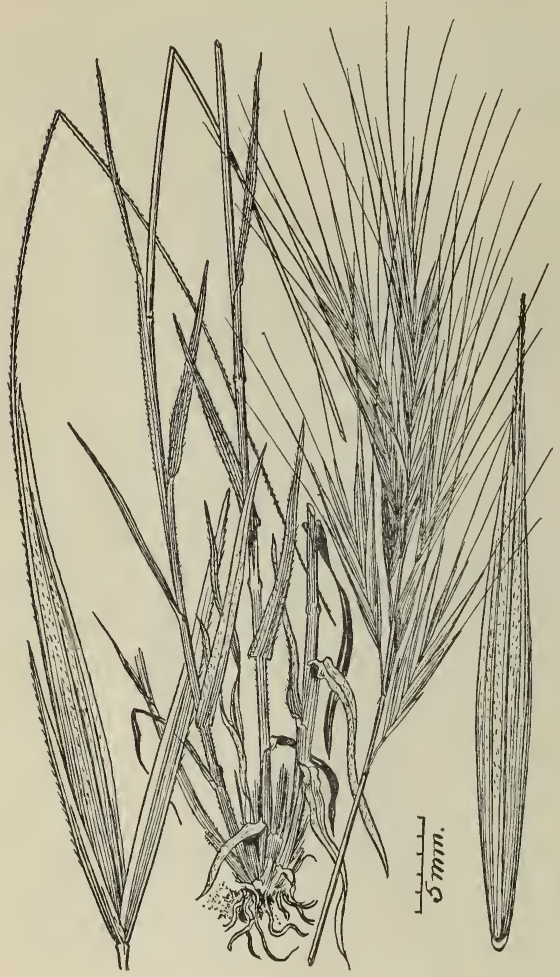

Fig. 16.-Ripgut (Bromus rigidus).

rigid awn sometimes 3 in. ( 7.5 $\mathrm{cm}$.) long. The florets of this and of red brome grass are sharp pointed at the base and at maturity are hard and rigid. (Fig. 16).

JUNE BROME GRASS (Bromus tectorum) is rarely over $18 \mathrm{in.} \mathrm{(45}$ $\mathrm{cm}$.) tall. It is downy throughout with conspicuously drooping panicles of narrow spikelets, much smaller than those of the two other injurious brome grasses.

Distribution and Habitat.These species are most abundant on the winter ranges where they occur throughout the state, seldom growing in dense stands even at elevations where yellow pine occurs. They inhabit soils of various origin and moisture conditions but are most abundant on clayey lands of low fertility where the better perennial species do not flourish. Red brome grass forms the densest cover and often occupies areas of hundreds of acres to the practical exclusion of other plants. "Ripgut" and June brome grass seldom form pure stands but they frequently constitute a fair proportion of the composite type. All are rapid-growing, comparatively drought-enduring species.

Forage Value and Reproduction.-Germination takes place promptly in the autumn following the rains. By about the middle of March a goodly proportion of the heads have formed, many of which early in April have mature seeds. From then until the seeds are cast mechanical injury may occur to any class of stock. The sharp-pointed florets lodge between the teeth, in the gums, the back of the tongue, and the throat, the barbed awns serving to work them into the flesh, causing great suffering and loss in weight and condition. Sometimes the intestines 
are pierced, causing death. Cattle sometimes develop a disease called "big jaw," caused by the awns accumulating in a great mass in the throat and behind the tongue. Cowmen make it their business in late spring and in the summer to remove from throat and tongue these "devil prongs," as they are called. The awns also get into the eyes and they frequently pierce the skin, especially of sheep. Until the panicles are fairly well developed the large annual growth of herbage of red brome grass and June brome grass is cropped with good results by all foraging animals, these plants sometimes being second to no others in importance in the fore part of the growing season. The leafage of needle brome grass, on the other hand, is harsh and tough even when young, hence is grazed very little and never by choice at any time. On many ranges, notably those overstocked, the invasion of needle brome grass is so rapid and the stand so dense that stockmen have become alarmed and have requested special investigation with a view to holding in check this "devil" grass.

In certain sections of southern California cattle no longer fatten on grass because of the decline in the stand of the better forage plants and the attending mechanical injury of needle brome grass. Moreover, sheepmen have had to abandon ranges heavily infested with this grass. The amount of seed produced by these undesirable plants is large, especially in red brome grass and "ripgut." Ranges infested with these injurious species require skillful management. The grazing plans must provide for the production and planting of the seed of the better species.

\section{FESCUE GRASSES (FESTUCA)}

Of the twenty-six fescue grasses credited to the state thirteen are perennials, but only about seven are of much value as forage. None of the annual species are pasture plants of first rank. Some of the fescues are among the most valuable of forage grasses, and being commonly associated with the perennial blue grasses, are moderately high in the stage of plant development. The annuals, generally called squirrel grasses, are essentially weeds and as such are often gregarious in waste places, and especially on heavily packed soils and excessively grazed areas. The best fescues produce an abundance of basal leafage which is comparatively fine and therefore more palatable to sheep and goats.

The most valuable kinds are: Idaho fescue, western fescue, spiked fescue, mountain bunch grass, bearded fescue, and California fescue.

Description of Fescue Grasses.-These are annual or perennial bunch grasses, with simple culms, mostly narrow, often inrolled blades and open or narrow panicles. 
KEY TO SPECIES

1a. Plants perennial.

2a. Blades inrolled or very narrow, or if nearly $1 / 4 \mathrm{in}$. (6 mm. wide) not stiff and rough.

3a. Lemmas awned; foliage fine, rolled.

4a. Blades rough, rather stiff.

1. F. idahoensis.

4b. Blades smooth, soft

2. F. occidentalis.

3b. Lemmas awn-tipped; blades mostly flat.

3. F. viridula.

$2 \mathrm{~b}$. Blades flat or coarse and with inrolled margins.

5a. Lemmas long-awned; blades flat, soft, $1 / 4-5 / 8$ in. (6-9 mm.) wide....

4. F. subulata.

5b. Lemmas awnless or sharp-pointed only; foliage coarse, harsh.

6a. Panicle very open.

5. F. californica.

6b. Panicle spike-like

6. F. confinis.

1b. Plants annual

7. F. megalura and other annuals.

\section{Perennial Fescues}

1. Idaho fescue (Festuca idahoensis) is very densely tufted, the

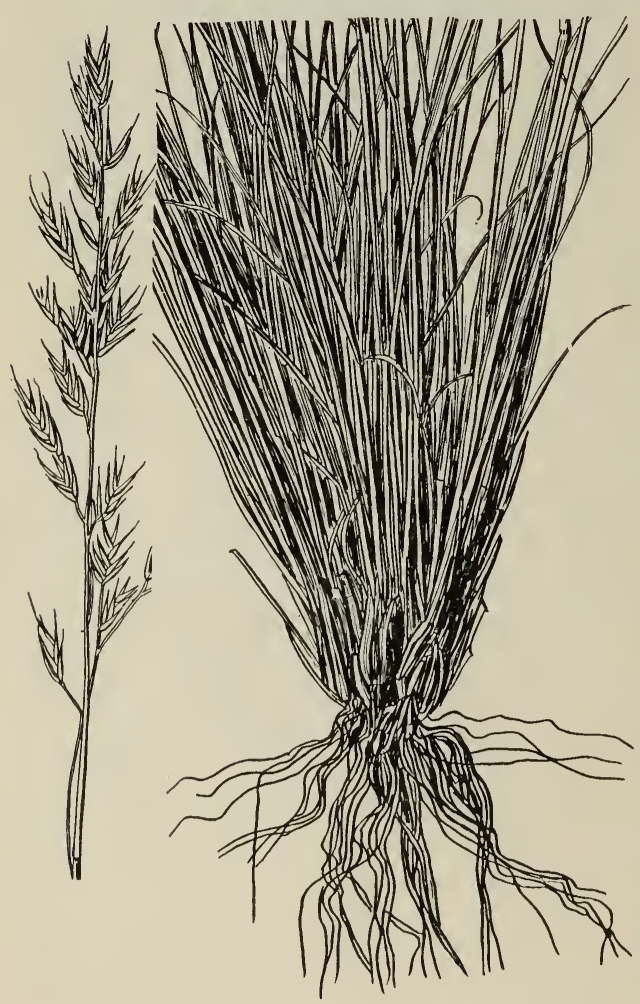

Fig. 17.-Idaho fescue (Festuca idahoensis). fine foliage rough, and, in exposed situations, commonly somewhat curled; panicles mostly narrow, the nearly simple branches spikelet-bearing almost to the base; spikelets shortawned, sometimes tinged with dull purple. (Fig. 17).

Distribution and Habitat.-Idaho fescue occurs throughout the state between elevations of about 1,000 and 7,500 feet. The most luxuriant growth and best stands are on arid lands, notably in the yellowpine-sugar-pine type, or in the arid transition life zone. It is a characteristic grass of exposed hills and mountain slopes, where it sometimes constitutes the dominant vegetation. Bunch wheat grasses and blue 
grasses are commonly the associated plants. It makes a good growth on soils of average fertility and moisture.

Forage Value and Reproduction.-Idaho fescue forms an important part of the forage for all herbivorous animals, including deer, elk, and other big game. The leafage is consumed closest early in the season, for as the seed matures the herbage becomes rather harsh and unpalatable. Even then horses and cattle take a fair proportion of the herbage, but sheep prefer a more succulent menu. After the autumn rains a secondary growth is produced and this, with the old leafage, made tender by the moisture, is grazed with good results by all grazing animals. A seed crop of moderate abundance and fair germination strength is produced. ${ }^{9}$ The seed ripens in June at elevations of about 1,000 feet, but at higher altitudes not until early August. After the seed falls it is good practice to graze the pasture in order to tramp in the seed, the better to insure germination and establishment.

Alpine Fescue (Festuca supina) is closely related to Idaho fescue but is rarely more than $6 \mathrm{in}$. (15 cm.) tall, in very dense tufts or hemispheric cushions of fine hard usually grayish-green foliage, the culms about twice as long as the foliage, or at high altitudes, scarcely exceeding it; panicles simple, very narrow. This is our smallest species. It is strictly alpine, occupying lands near and well above timberline. On Mt. Whitney it occurs as much as 1,500 feet above timberline but it grows only 1 or $2 \mathrm{in}$. high. The leafage is eaten with relish by livestock

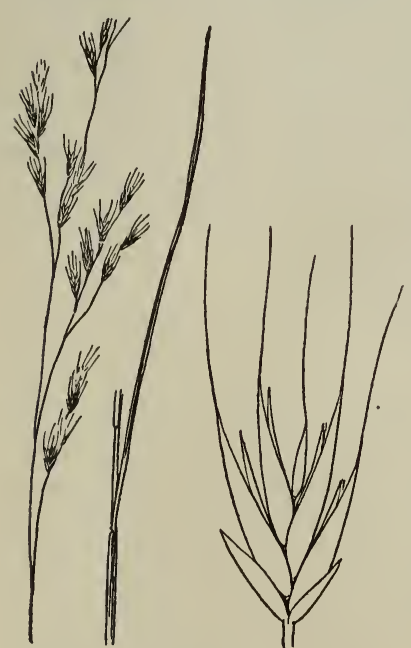
Fig. 18. - Western fescue (Festuca
occidentalis). but it is too small and sparse to be listed as an important forage plant. Because of the short growing season of the alpine region the production of seed is uncertain and small for a single plant. The flower stalks sometimes do not appear until late in September and it is doubtful if they then produce fertile seed. Ordinarily the seed does not ripen until October.

2. Western fescue (Festuca occidentalis) is densely tufted, the tall shining culms extending above an abundance of fine soft foliage; panicle $3-6$ in. (7-15 cm.) long, the slender, branches rather far apart and without spikelets at base; spikelets longawned. (Fig. 18).

${ }^{9}$ Sampson, Arthur W. Important forage plants, their life history and forage value. U. S. Dept. Agr. Bul. 545:8-9. 1917. 
Distribution and Habitat.-This is a grass of open woods and rocky slopes between elevations of about 500 and 8,000 feet. It is most common in open pine and oak timber but grows in a variety of soils of varying moisture conditions. It is essentially a northern species but occurs as far south as central California. The best stands are found in the yellow pine belt but the growth is seldom dense.

Forage Value and Reproduction.-No fescue is cropped more closely than this, if all classes of stock and plant associations are considered. Cattle and horses leave only a portion of the flower stalks early in the season, while sheep consume the herbage with much relish, as it is fine and soft but do not crop the flower stalk. Western fescue is not so abundant as Idaho fescue. This may be accounted for by its less vigorous seeding habits and the somewhat higher palatability of its herbage. The seed crop ripens early. Near Mt. Tamalpais the seed matures early in June, whereas near Lake Tahoe, at an elevation of about 7,500 feet, the seed does not ripen until about July 15. Deferred grazing may be expected to bring good results in revegetation to western fescue.

3. Mountain bunch grass (Festuca viridula) is tufted, reddish at the nodes and at the very base, with an abundance of soft foliage; panicles 3-5 in. (7-13 cm.) long, somewhat nodding; the spikelets variegated purple and yellowish green, fading at maturity. (Fig. 19).

Distribution and Habitat.-Mountain bunch grass is a subalpine plant which grows on meadows and plateaus between elevations of about 6,500 and 10,000 feet. The best stands are in the forest types of spruce and fir. Like most bunch grasses even the densest stands do not occupy more than half the ground, the tufts being associated with many other plants of more or less forage value. The coarse, deep roots and the conservative use of water by the plant as a whole enable the species to occupy comparatively dry soils.

Forage Value and Reproduction.-No fescue is more palatable or probably more nutritious than mountain bunch grass. From early spring until late autumn this grass is sought by.livestock. Sheep graze the herbage more closely than that of most grasses. It is doubtful if any other fescue is grazed with as great avidity throughout the season. A small amount of new basal leafage usually develops when the autumn rains come and this adds greatly to the palatability of the herbage as a whole. The flower stalks begin to appear early in July and most of them have been produced a month later. The seed matures during August and early in September. It does not shell out immediately at maturity, a peculiarity which has proved advantageous in collecting seed for revegetating depleted areas and in attempts to extend the 


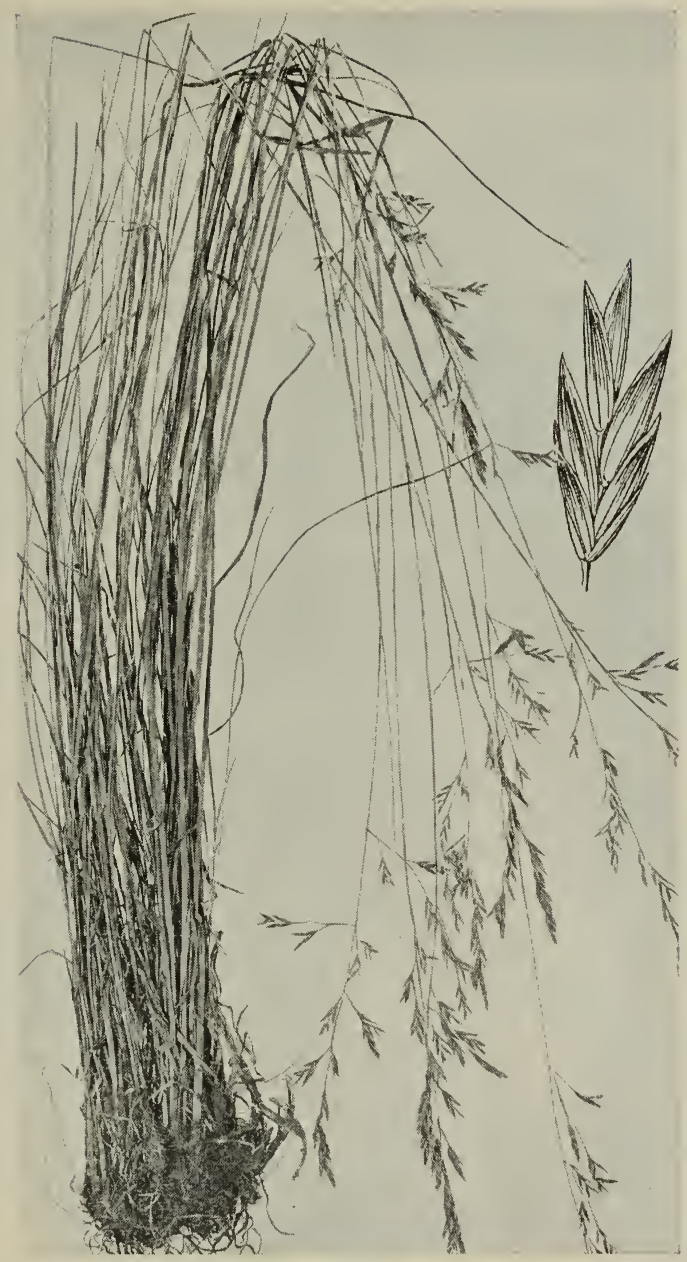

Fig. 19.-Mountain bunch grass (Festuca viridula).

range of this valuable plant. A comparatively big seed crop is produced if the stand has not been seriously weakened by overgrazing. Moreover, the germination strength of the seed is good in favorable habitats. Germination tests made in the laboratory, however, in spite of attempts to so control the temperature as to simulate that of the native habitat were invariably much lower than those conducted in the field.

4. Bearded fescue (Festuca subulata) is $2 \frac{1}{2}$ to over $3 \mathrm{ft}$. $(75-90 \mathrm{~cm}$. tall, the culms solitary or few together; lower sheaths thin and brown; blades $1 / 4^{-5 / 8}$ in. $(6-10 \mathrm{~mm}$.) wide, drooping; panicle large but few 
flowered, the green long-awned spikelets somewhat clustered towards the ends of long slender drooping branches. It is our broadest-leaved species.

Distribution and Habitat.-This rather "stemmy" plant grows from near sea level in the humid coastal region to about 8,000 feet in the lower limits of the spruce-fir type. The favorite habitat is open woodland, stream banks, and moderately moist meadows. It nowhere makes a dense cover nor is it ever a dominant species. It is less drought enduring than most perennial fescues.

Forage Value and Reproduction.-Bearded fescue is only moderately palatable to foraging animals, because of the relatively scant leafage. Sheep, for example, graze it with considerably less relish than that of Idaho fescue and mountain bunch grass. The seed ripens early, in the lower elevations ripening and falling early in July. More generally it reaches maturity late in July or early in August.

5. California fescue (Festuca californica) is a coarse grass in large clumps, the culms $3 \mathrm{ft}$. (90 $\mathrm{cm}$.) or taller; blades inrolled, rather coarse and harsh with a fringe of short hairs at the

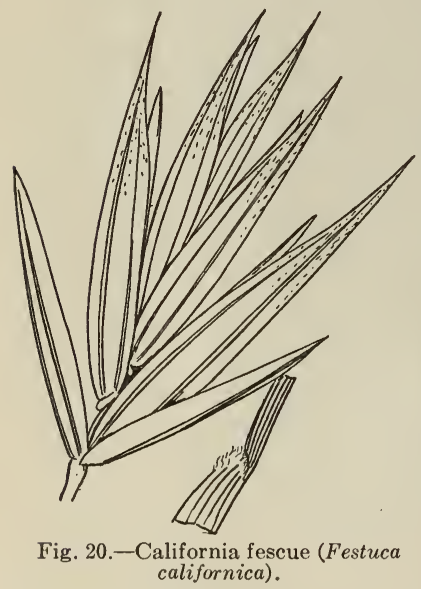
junction with the sheath; panicle large and open; spikelets larger than in any of our other species, the lemmas awn tipped. (Fig. 20).

Distribution and Habitat. - California fescue ranges from sea level in the San Francisco Bay region to 6,000 feet or more in Siskiyou and adjoining counties. The plant occurs sparingly on the winter ranges but is somewhat more abundant in the yellow pine type. It never forms a dense cover over a large area.

Forage Value and Reproduction.-Because of the dense bunchy habit of growth, the culms sometimes numbering 100 or more to a tuft, and the harsh, coarse leafage, the herbage is not highly relished by livestock. Sheep graze the plant only early in the spring. Horses feed upon the leafage, grazing it much more closely than cattle. The seed crop ripens in May on the foothill ranges and in June in the yellow pine type. The amount of seed produced is fairly large.

6. Spiked fescue (Festuca confinis) has rather stout culms, mostly $2-2 \frac{1}{2} \mathrm{ft}$. $(60-75 \mathrm{~cm}$.) tall, in rather small clumps, commonly producing short brown rootstocks; blades rather coarse and stiff ; panicle 3-6 in. (7$15 \mathrm{~cm}$.) long, narrow, pale, the spikelets rather soft, somewhat crowded. 
Distribution and Habitat.-Spiked fescue grows between elevations of about 4,500 and 9,500 feet, being most abundant in the yellow pine type. It occurs sparingly, mostly in rather dry situations with other fescues, wheat grasses, and rye grasses.

Forage Value and Reproduction.-As sheep forage spiked fescue is valuable only until the seeds begin to form. After that the leafage becomes tough and fibrous. Cattle and horses, however, devour the leafage with moderate relish throughout the growing season, but with much relish after seed maturity. The seed crop begins to ripen late in July and by the latter part of August it is mostly disseminated. The reproductive powers are not strong, for even on lands protected from grazing for several years there is only a scattering growth.

\section{Annual Fescues or Sgutrrel Grasses}

There are thirteen species, all more or less inferior range forage plants. They are confined chiefly to the foothill and low ranges where, notably on badly depleted lands, they commonly form the main cover.

7. Six-weeks fescue (Festuca megalura) is typical of this group.

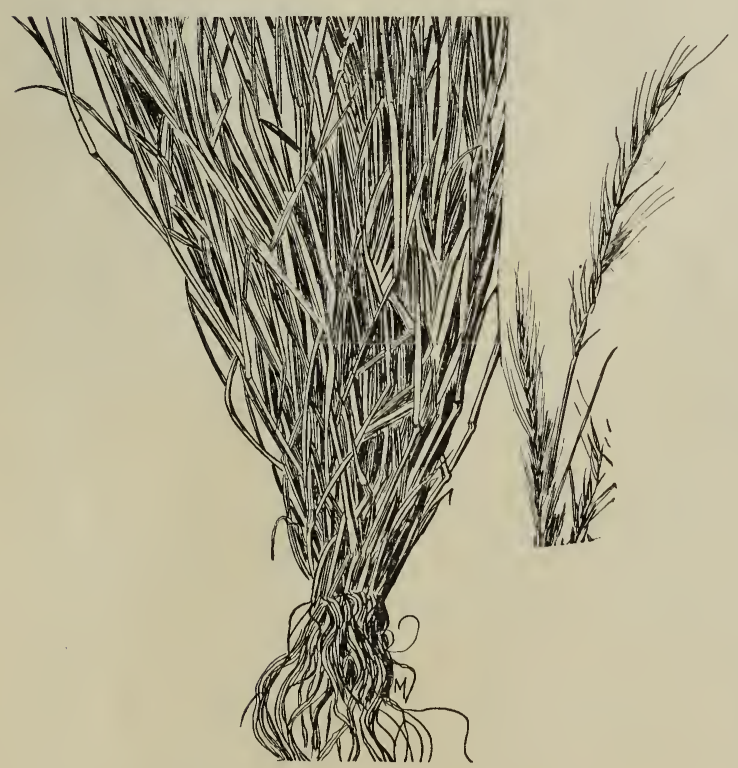

Fig. 21.-Six-weeks fescue (Festuca megalura). It is slender, $1-2 \mathrm{ft}$. $(30-60 \mathrm{~cm}$.$) tall, in$ small tufts, the flowering culms of a tuft mostly very unequal in height; foliage fine and soft; panicles narrow, almost bristly from the long awns. (Fig. 21).

Distribution and $H a b i t a t$. -Waste places, soils heavily packed by excessive stocking, and open timber lands of medium elevations, especially in the Coast Range, are common habitats. The destruction of the perennial herbage invariably results in an abundance of this and other annual fescues. 
Forage Value and Reproduction.-Annual fescues in general pull up readily by the roots when grazed and are therefore not desirable pasture plants. $^{10}$ As fillers, before the herbage dries, however, they have some forage value. The copious seed crop ripens in May and June.

\section{MELIC GRASSES (MELICA)}

There are thirteen melic grasses in California, a greater number than is found in any other state, but only about nine of these have any particular forage value. No melic grass is of prime importance in beef and mutton production. As a whole they are moderately palatable, some species being grazed closely by all kinds of livestock, but they do not make a dense growth except in restricted areas. Because of the sparse stand and scant foliage of most of them, the melic grasses must be classed as "fillers," that is, as food second in importance to other grasses no more palatable but of greater abundance and wider distribution. The most valuable species inhabit the summer ranges, where some of them are grazed each season to within a few hundred feet of timber line.

The melic grasses are comparatively early in the succession or developmental trend with respect to revegetation, most species being represented in the early formation of the mixed grass-and-herb stage, hence they are plants of moderate drought-endurance. Because the seed of most melic grasses is fairly large range revegetation is hastened if the lands are grazed after seed maturity, in order that the seed crop may be trampled into the soil.

Description of Melic Grasses.-Melic grasses are perennials growing in dense or rather loose clumps, with simple culms, often more or less bulblike at the base; sheath margins united except at the summit; blades rough, not over $1 / 4 \mathrm{in}$. $(6 \mathrm{~mm}$.) wide; spikelets rather showy, the uppermost florets small and sterile.

\section{KEY TO SPECIES}

1a. Spikelets less than $1 / 4$ in. ( $5 \mathrm{~mm}$.) long with 1 or 2 fertile florets

1. M. imperfecta.

1b. Spikelets $1 / 4-1 / 2$ in. (6-12 mm.) long with 3-5 fertile florets.

2a. Culms bulblike at base 2. M. bella.

2b. Culms not bulblike at base or but slightly swollen.

3a. Spikelets nodding in a simple panicle, showy..... 3. M. stricta.

3 b. Spikelets erect or appressed to the panicle branches.

4a. Spikelets awnless

4. M. bulbosa. 4b. Spikelets awned.

5. M. aristata.

${ }^{10}$ Griffiths, D., G. L. Bidwell, and C. E. Goodrich. Native pasture grasses of the United States. U. S. Dept. Agr. Bul. 201:25. 1915. 
1. Small-flowered melic grass (Melica imperfecta) is commonly $21 / 2-3 \mathrm{ft}$. (75-90 cm.) tall, in rather large loose tufts, the lower sheaths

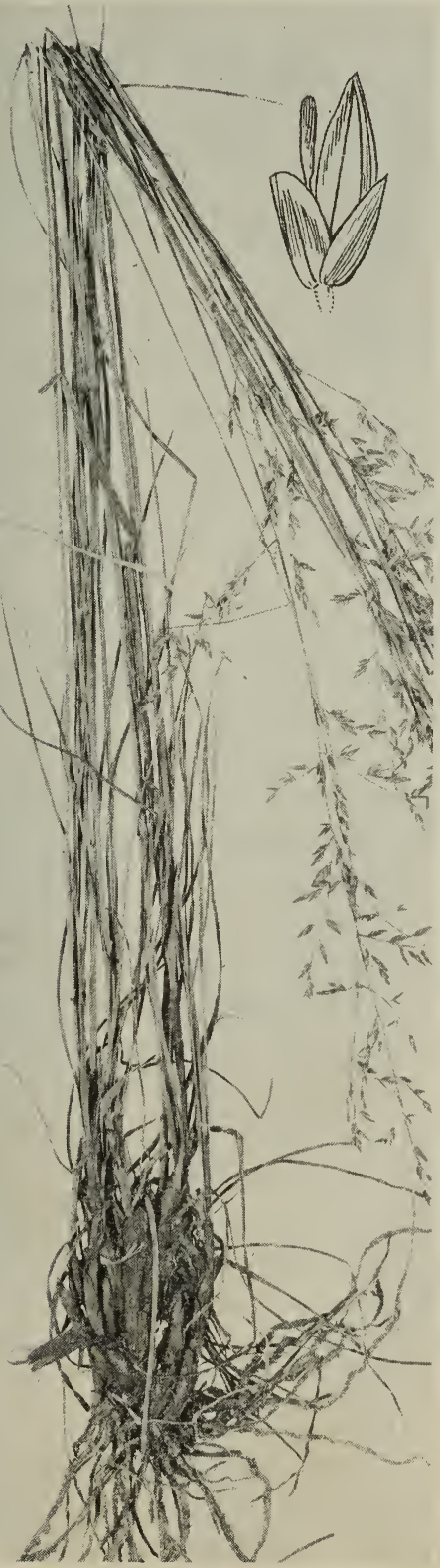

Fig. 22.-Small-flowered melic grass (Melica imperfecta). brown, thin and papery; foliage abundant; panicles $6-10$ in. (15$25 \mathrm{~cm}$.) long, spikelets less than $1 / 4$ in. (5-6 mm.) long (smaller than in any other melic grass), variegated pale green and purple, fading at maturity; fertile floret usually 1, not hairy. (Fig. 22).

Distribution and Habitat.This grass is found throughout the state, growing from nearly sea level to about 6,500 feet. The best stands are found in the foothill and low mountain lands, in pine woods, open chaparral, and exposed bleak hillsides. The plant is unusually tolerant to shade. Shallow, comparatively infertile soils sometimes support an excellent cover of smallflowered melic grass, notably in the Coast ranges, but rich moist or even wet lands are not adverse to its growth. The plant is a conservative user of water, for its growth cycle is completed in unusually dry situations.

Forage Value and Reproduction.-This species produces more choice forage than does any other melic grass in the state. On the winter or lower ranges growth begins with the autumn rains and continues through the winter and early spring. All classes of stock feed greedily upon the plant during this period, the result being that the stand is waning seriously in many localities. Horses and cattle take the flower 
stalks with the leafage during the active period of growth, but sheep devour only the leafage until in the autumn when, like other livestock, they eat the seed heads also. In southern California (San Diego County) the flower stalks begin to appear early in March and the seed ripens in May, but farther north, May and late July are the periods, respectively, of flower-stalk production and seed maturity. Unfortunately most of the winter ranges are closely grazed before the seed ripens, so that the plant is declining in abundance. The seed habits are strong, a fairly large amount of seed being produced by strong healthy plants in favorable seasons.

TORREY MELIC GRASs (Melica torreyana) is closely related to smallflowered melic grass, but is of more restricted range. The panicles are narrower and the spikelets are larger, and there are two minutely hairy fertile florets. It inhabits thickets and timbered lands, seldom above 1,500 feet elevation, and is most common in central California, especially in the Bay region. Its forage value is similar to that of smallflowered melic.

2. Purple melic grass (Melica bella) grows in loose clumps, the slender culms with bulblike bases, a single clump sometimes having as

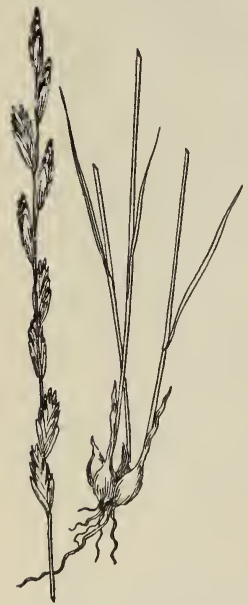

Fig. 23.-Purple melic grass (Melica bella). many as ten bulbs, appearing like a cluster of little onions; foliage rather scant; panicle $3-6$ in. (7-15 $\mathrm{cm}$.$) long, narrow, the short branches erect; spikelets$ purple or variegated, fading at maturity. This and the following four species with the bulblike bases, are sometimes called onion melic grass. (Fig. 23).

Distribution and Habitat.-This is a northern species, common in Washington and Oregon, and in California confined to the northern part. The elevational range is from 1,500 to 9,500 feet above sea level, but the best stands are in the yellow-pinesugar-pine zone, where the grazing is best early in the summer and late in the autumn. It occurs but sparsely in the winter ranges, nowhere producing a dense cover. Even in the rich sandy or clay loam parks, where the species thrives best, it probably never forms the dominant vegetation. It occupies areas that receive a moderate amount of sunshine, such as open timber lands or meadows, and well-drained, fairly most soils of moderate fertility.

Forage Value and Reproduction.-The herbage is grazed with relish by all classes of foraging animals during the period of growth. Sheep graze the leafage closest early in the season but when autumn 
approaches the foliage becomes somewhat harsh and unpalatable. The seed heads, when well formed, are devoured by all foraging animals, by horses especially, and by sheep to a less extent. The flower stalks begin to appear early in May in the yellow-pine-sugar-pine type and they continue to be produced as late as August in the most elevated areas. The seed ripens between July 15 and September 15, according to elevation, slope, and the character of the season. The seed habits are not strong, yet this graśs responds moderately well to judicious forage use. The seeds fall as soon as they reach maturity.

SHOWy MELIC GRASS (Melica spectabilis) resembles purple melic grass, but the spikelets are on very slender pedicles, more or less nodding. The foliage is also sparse. This grass is found only in the northern part of the state where typically it inhabits open or rocky woodland or chaparral of the yellow-pine-sugar-pine type to an elevation of about 7,500 feet. In the mountains of Mendocino County, however, it occurs as high as 10,000 feet. It also thrives in moist meadows and bottomlands.

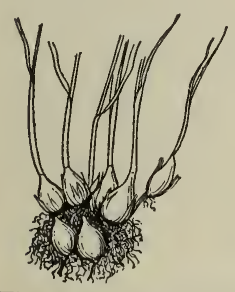

Fig. 24.-Base of small melic grass.

Small Melic Grass (Melica fugax) is another species with bulblike bases (fig. 24). It is rarely over 15 in. $(38 \mathrm{~cm}$.) tall, and has open panicles, the short branches stiffly spreading. It is found mostly on dry slopes above 5,000 feet elevation, from northern California to the region of Lake Tahoe. It is most common in the yellow pine type, where it occupies dry exposed hillsides and open woodland.

GeYer melic grass (Melica geyeri) is taller and coarser than any of the other onion melics being $21 / 2-5 \mathrm{ft}$. $(75-150 \mathrm{~cm}$.) tall, with blades $1 / 8-1 / 4$ in. (3-6 mm.) broad; the bulblike bases long-tapering; panicle 6-8 in. (15-20 cm.) long, with slender spreading distant branches, and spikelets nearly $3 / 4$ in. (18 mm.) long, narrow, purplish, somewhat resembling those of brome grasses. Its range is the northern half of the State. The moisture and soil requirements are somewhat more exacting than of the closely related species, being found most abundantly along stream banks, in moist meadows, and in fertile coves. The center of distribution in the State is near Truckee. In the northern Coast Range it seldom occurs abundantly above 6,000 feet elevation. It is also commonly found in the digger-pine-oak-brush belt.

Alaska melic gráss (Melica subulata) resembles Geyer melic grass, but is generally more slender, with comparatively slender panicles and long-pointed spikelets. It is found in northern California at elevations of about 2,500 feet, in Humboldt County, to about 7,000 feet, and in 
the region of Lake Tahoe. Shady slopes, meadows, and semi-wet areas are typical habitats. The forage value and the seed maturity of these five species are much the same. They are palatable to all classes of stock, but Geyer melic grass, because of its robust growth, is utilized better by cattle and horses than by sheep and goats. By early August the seed has usually ripened and been disseminated.

3. Nodding melic grass (Melica stricta) is densely tufted, the

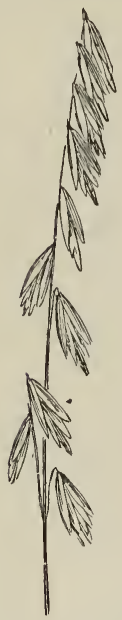

Fig. 25. - Nodding melic grass (Melica stricta). sheaths violet, thin and papery; culms mostly 8-15 in. (20-38 cm.) tall; foliage fairly abundant, sometimes rather velvety; panicle narrow, simple, the large handsome purplish or pearly spikelets nodding. (Fig. 25).

Distribution and Habitat.-This grass grows sparsely throughout the State between elevations of about 4,000 feet in the north to 10,000 feet in the Sierra Nevada range in Los Angeles County. The open yellow pine forests support the best stands. As indicated by its presence on rocky ledges and knolls, and the luxuriant growth along stream banks, it is a drought-enduring plant, but it responds to favorable environment.

Forage Value and Reproduction.-The leafage is grazed closely by cattle and horses throughout the normal grazing season. Sheep seem to graze the leafage closely only during the active season of growth.

4. California melic grass (Melica bulbosa) is $2-21 / 2 \mathrm{ft}$. $(60-75 \mathrm{~cm}$.) tall, the culms slightly swollen at the base and usually bent an inch or two from the very base, forming loose tufts; foliage rather scant;

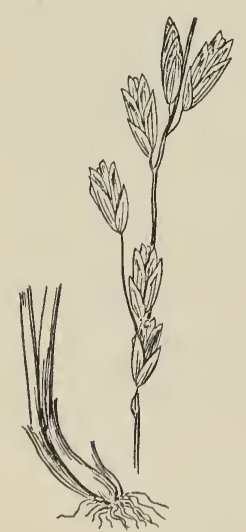

Fig. 26.-California melic grass (Melica bulbosa). panicle $6-9$ in. (15-28 cm.) long, mostly narrow and rather dense, or the branches slightly spreading at flowering time; spikelets blunt, pale brownish or purple-tinged. (Fig. 26).

Distribution and Habitat.-This is essentially a Pacific coast plant, presumably of much more scattered growth now than formerly, because of excessive grazing, for in protected areas, as on shrubby lands, or fenced plots, the stand is well maintained. It occupies very dry sites and is an unusually drought enduring plant. It ranges in elevation from sea level to about 5,000 feet.

Forage Value and Reproduction.-California melic grass is grazed with moderate relish. Much of the growth is on ledges and other places inaccessible to 
foraging animals. The leafage is grazed closely by sheep and goats only when succulent. The flower-stalks begin to appear in May and continue to be produced until early June. The seed crop reaches maturity in August. The amount of seed produced to a plant is fairly large. Re-establishment of this plant should be possible under good grazing management, judging from the cover seen in protected areas.

TALL MELIC GRASs (Melica frutescens) is closely related to California melic grass. It is taller, rather coarse and woody, with longer panicles of pale glistening spikelets. Unlike any of our other melic grasses this species often produces leafy branches from nodes a few inches above the base. It is confined to southern California where it occupies brushy desert flats and foothill ranges. In forage value it is similar to that of California melic grass.

5. Awned melic grass (Melica aristata) grows in dense tufts, the slender culms mostly $2-3 \mathrm{ft} .(60-90 \mathrm{~cm}$.) tall; the foliage is fairly abundant; panicles narrow, the short branches ascending or erect, or nearly simple and somewhat resembling slender spikes of some of the wheat grasses; spikelets with slender awns $1 / 4-1 / 2$ in. (6-12 mm.) long.

Distribution and Habitat.-It is found in dry woods, grassy slopes, and medium moist meadows in northern California, southward in the Sierra Nevada Mts. to Tulare County. The range in elevation is between 2,500 and 7,500 feet.

Forage Value and Reproduction.-In spite of the awns this melic grass is grazed with relish by all classes of stock. At the time of seed maturity, however, the herbage becomes somewhat unpalatable to sheep. The flower stalks appear in May and June and the seed ripens in July and August. The amount of seed produced to a plant is small.

\section{BLUE GRASSES (POA)}

The fame of the pastures of Kentucky is due to a superior grass which owes its common name of Kentucky blue grass to this association. The grazing grounds of California are greatly enriched, likewise, by no less than 30 different kinds of blue grasses. Most blue grasses do not flourish where the summers are hot and dry as on the foothills, but on the summer pastures or mountain ranges they are stable forage producers. Four are winter annuals, three of which afford some early spring grazing in the deserts and foothills. The rest which are perennials begin growth early in the spring, are relatively succulent during the growing season, and remain palatable and nutritious after the herbage cures. They are comparatively long-lived plants and most of them, notably those with rootstocks, withstand grazing well. Blue grasses are 
primarily pasture plants, but a few are cut for hay. They are comparatively abundant in the development of the climax or more stable herbaceous cover. They nearly always replace the brome grasses, but usually give way to certain species of needle grasses (Stipa) and wheat grasses (Agropyron). The blue grasses are plants of sweet or somewhat limey or slightly alkaline lands; they never grow

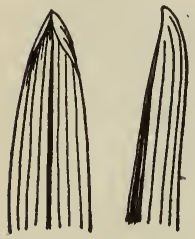

Fig. 27.-Tip of leaf of blue grass. luxuriantly, if at all, on acid or sour lands. They are sometimes called spear grasses or meadow grasses.

Description of Blue Grasses.-The blue grasses are slender perennials or annuals, growing in tufts or forming a sod, with rather soft foliage, the blades long and narrow and with a boat-shaped tip (fig. 27). The flower heads are narrow or loose panicles of small awnless spikelets. The largest forage yields are produced by about 14 species, as follows:

Sod Blue Grasses

Kentucky blue grass

Canada blue grass

Olney blue grass

\section{Bunch Blue Grasses}

Malpais blue grass

Sandberg blue grass

Pacific blue grass

Nevada blue grass

Alkali blue grass

Fendler blue grass

Leiberg blue grass

\section{Annual Blue Grasses}

Annual blue grass

Bigelow blue grass

Bolander blue grass

Howell blue grass

\section{KEY TO SPECIES}

1a. Plants perennial.

2a. Sod grasses with creeping rootstocks.

3a. Culms not flattened.

4a. Florets with a tuft of cottony hairs at base

4b. Florets without cottony hairs.

1. P. pratensis.

b. Culms flattened.

3. P. nervosa.

b. Bunch grasses (without creeping rootstocks).

5a. Blades flat, somewhat curly 2. P. compressa.

5b. Blades folded or rolled, rather stiff.

7a. Blades relatively short and crowded at base.

4. P. scabrella.

7b. Blades elongate, scattered along the culm

P. fendleriana.

1b. Plants annual.

P. nevadensis.

5. P. annua.

\section{Sod Blue Grasses}

1. Kentucky blue grass (Poa pratensis) at its best forms a complete sod, but it usually grows in small patches, close together or distant, among other vegetation; it is 1-3 ft. (30-90 cm.) tall, the foliage soft and long; panicle open, the spikelets clustered toward the ends of the branches. (Fig. 28). Other common names are June grass, or simply blue grass. 


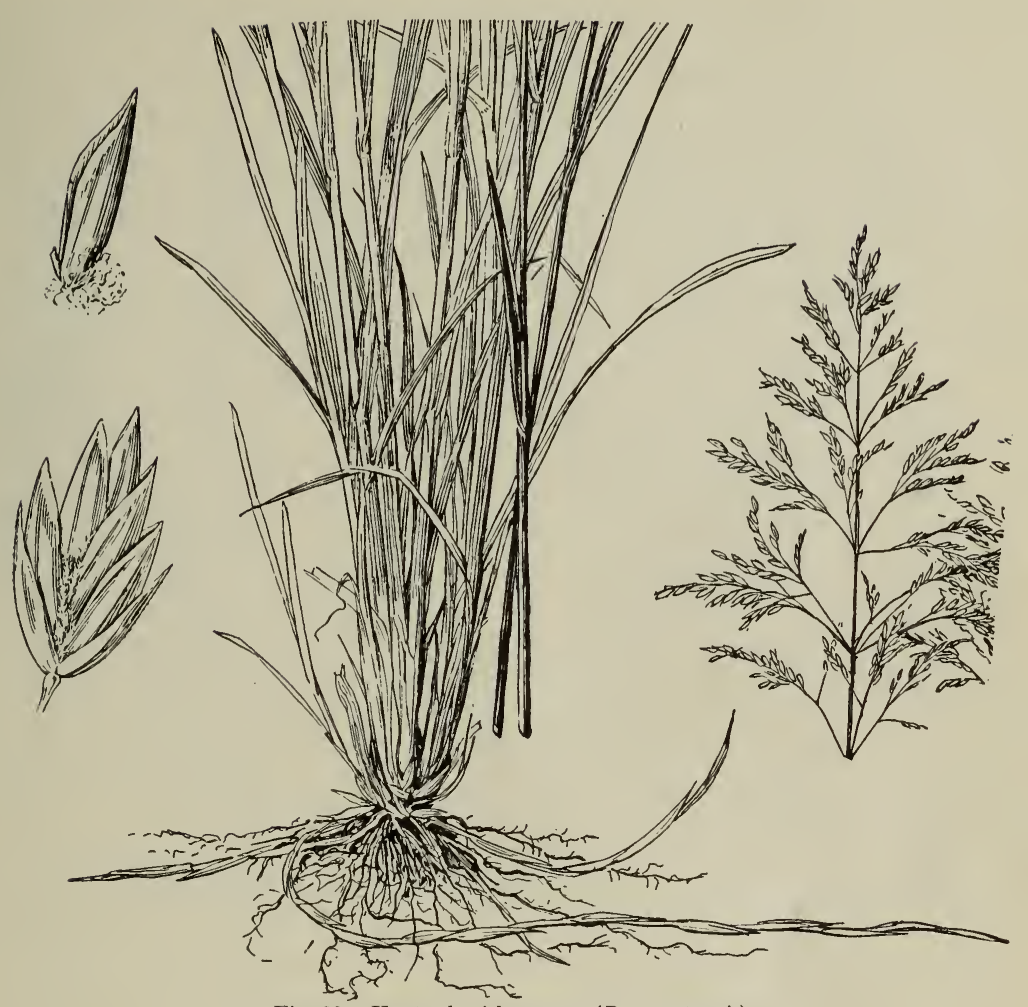

Fig. 28.--Kentucky blue grass (Poa pratensis).

Distribution and Habitat.-In California, Kentucky blue grass is rather strictly confined to cool elevated areas. In the middle West and the North, it is an ideal lawn grass, but it does not make a satisfactory lawn in California, because it does not withstand the hot summers. On the summer range good stands are sometimes found at an elevation of 10,000 feet. While some seed of Kentucky blue grass has been scattered on certain ranges on which it now grows, most of the present cover has come in naturally, and on many areas it is gaining in abundance. A few years ago it was practically unknown on certain ranges where now it is common.

Forage Value and Reproduction.-All grazing animals relish Kentucky blue grass. Cattle and horses devour the whole plant during the grazing season, whereas sheep usually seek only the leafage which, however, they graze closely. Being a sod-former close grazing, if not too frequent, does not injure it. Once the Kentucky blue grass plants are well established reproduction by shoots arising from the rootstocks is 
vigorous, but seedlings also occur where a seed crop is permitted to form. From the rapidity with which the species spreads without cultivation its seed habits must be strong. With its tuft of cottony hairs at the base, the ripened floret (the seed) is carried long distances by the wind. In the higher ranges, as in the spruce-fir type, the seed usually ripens by the middle of August. After the first season's growth the plants form rootstocks and begin stooling out.

2. Canada blue grass (Poa compressa) forms a looser sod than Kentucky blue grass; the culms are flat and wiry and the foliage less abundant; panicles narrower and denser. (Fig. 29).

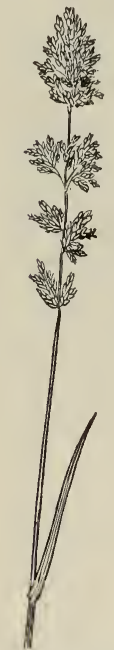

Fis. 29.-Canada blue griss (Pou compressa). It is known also as English blue grass, Virginia blue grass, and flatstem blue grass.

Distribution and Habitat.-Canada blue grass is an introduction from Europe. It is most commonly found between elevations of about 6,000-10,000 feet. On the more productive mountain lands it may pay to attempt to extend its range or increase its abundance by artificial reseeding. The yield is not so large as that of Kentucky blue grass, with which it often grows in the better sites, but it does well on soils where Kentucky blue grass does not thrive.

Forage Value and Reproduction.-While the palatability is not so high as that of Kentucky blue grass, the herbage is of average palatability for all classes of livestock. The rather loose turf does not withstand so much abusive pasturing as do some plants that form a dense sod, but it produces more forage and can be cropped more closely without permanent injury than any of the bunch blue grasses. The seed habits of Canada blue grass are good. Seed may be purchased for about half the cost of that of Kentucky blue grass. Where closely, but not destructively grazed, reproduction from the rootstocks is vigorous.

3. Olney blue grass (Poa nervosa) resembles Kentucky blue grass, but the foliage is paler and not so long; the panicle is rather more open and the florets have no cottony tuft at the base. (Fig. 30). This is an exceedingly variable species and its forms are known under different names. A luxuriant form with rather rough leaves has been called Poa olneyae (described from Washington specimens), while plants having hairs on the nerves of the lemmas have been called Poa wheeleri. True Poa wheeleri is a Rocky Mountain species scarcely

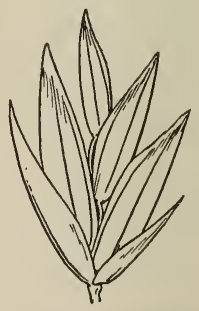

Fig. 30.-Olney blue grass (Poa nervosa). distinct from $P$. nervosa. 
Distribution and Habitat.-Olney blue grass is a plant of the summer range, growing at elevations of between 4,500 and 12,000 feet. It is

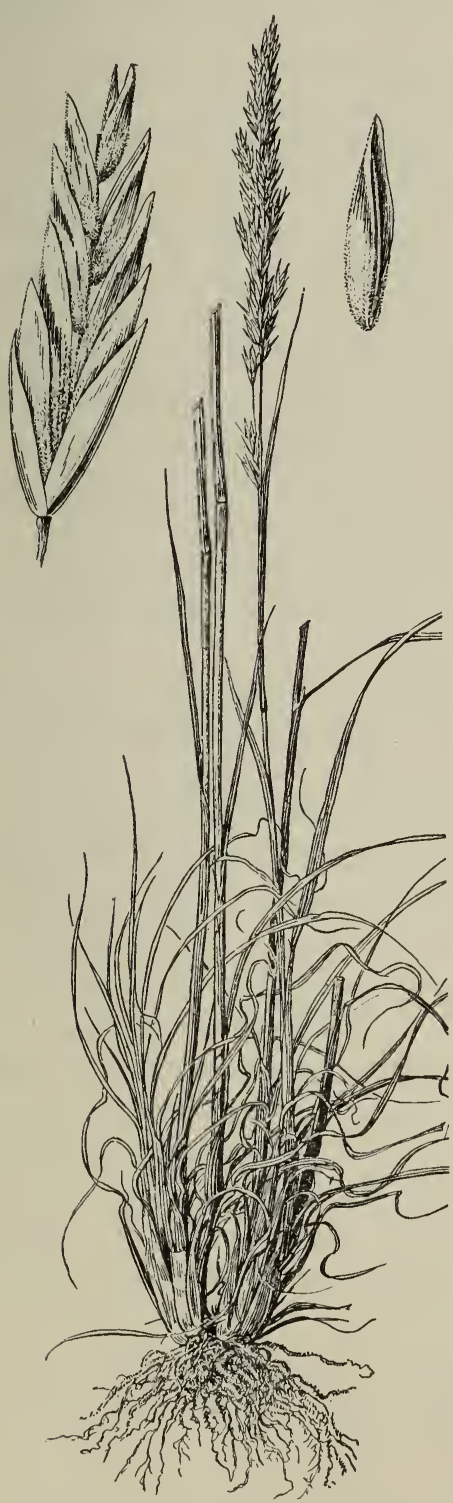

Fig. 31.-Malpais blue grass (Poa scabrella). most common on alpine meadows, open woods and grassy hillocks in the Sierra Nevada and high mountains in the South. Being a comparatively droughtenduring species it thrives on rather poor as well as on fertile soils. In many localities it grows abundantly and often forms the dominant vegetation. It holds its own in competition with other grasses and broad-leaved herbs, especially with plants that do not form a turf.

Forage Value and Reproduction.Olney blue grass is a very choice forage plant, both because of the avidity with which all classes of livestock graze it and because of its ability to recover from close and repeated grazing. No other native blue grass apparently withstands grazing as well as does this species. The seed, which is usually abundant and viable, matures about August or September. The first year's seedlings are stocky and fairly well rooted, but their roots are pushed out of the ground rather easily, even in the autumn, if the grazing is close, especially in wet weather. Short rootstocks and an occasional shoot therefrom are produced in the second year of growth.

\section{Bunch Blue Grasses}

4. Malpais blue grass (Poa scabrella) forms dense tufts, as much as 4 in. (10 cm.) across, with a mass of rather rough foliage at the base, mostly $4-7$ in. (10-18 $\mathrm{cm}$.) high, the culms rather few to a tuft, reddish at the base, mostly $1 \frac{1}{2}$ to $2 \frac{1}{2} \mathrm{ft}$. (45-75 cm.) tall; panicle narrow but loose, the spikelets not so flat as in most blue grasses. (Fig. 31). 
Distribution and Habitat.-Malpais blue grass has an un usually wide elevational range, occurring practically from sea level to 9,000 feet altitude. It is most abundant in the upper yellow-pine-sugar-pine belt and in the Douglas fir type (Transition and Canadian life zones) but is often of primary importance on ranges of low elevation, notably in the coast counties. It grows in open ground on gravelly or thin soils, and in rocky outcrops resembling badlands, where it is one of the most drought-enduring plants. It is often the most abundant species, although, because of the low carrying capacity of the soils, it makes only open stands.

Forage Value and Reproduction.-Foraging animals relish the leafage of Malpais blue grass, which is always grazed closely until after seed maturity. In the autumn, unless there is much precipitation, the herbage is not grazed closely by horses. In the early summer the fine tender herbage is especially sought by lambs. The seed ripens unevenly, in June at the lower elevations and not until September in the higher altitudes. It drops soon after maturity. The seed habits are moderately strong.

SANDBerg Blue grass (Poa sandbergii) is much like Malpais blue grass but is rarely over $15 \mathrm{in} .(37 \mathrm{~cm}$.) tall and has shorter tufts of smooth foliage.

Distribution and Habitat.-Like Malpais blue grass this species grows on thin inferior soils, but unlike Malpais it does well on deep fertile soil. Its range is 2,000-10,000 feet, but it is most abundant at intermediate elevations. It grows both in partly shaded and in exposed situations, and next to Malpais blue grass it is the most abundant bunch blue grass in the State.

Forage Value and Reproduction.-The forage value of Sandberg blue grass is high, as it is grazed closely by all classes of stock during the

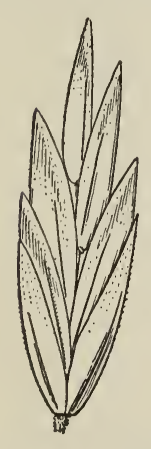

Fig. 32.-Nevada blue grass (Poa nevadensis). growing season. When the leafage has dried it is not grazed closely by sheep, but they seek it again after the rains when it has been somewhat softened. Seed production is not very large, but some fertile seed is usually produced each year. It ripens between July and early September.

Pacific Blue grass (Poa gracillima) is related to Sandberg blue grass. It grows in looser tufts, the culms usually bent at the base and it has an open panicle with spreading branches.

Nevada blue grass (Poa nevadensis) is coarser than Malpais blue grass, grayish-green, with rough inrolled blades, long narrow panicle, and spikelets $1 / 3-2 / 5$ in. (7-8 mm.) long. (Fig. 32). 
Alkali blue grass (Poa brachyglossa) is related to Nevada blue grass. It has finer smooth foliage and spikelets sometimes nearly $1 / 2 \mathrm{in}$. (12 mm.) long.

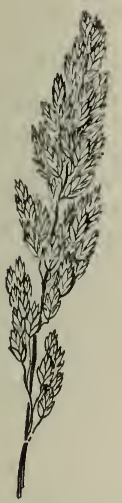

Fig. 33. -F en d ler blue grass (Poa fendleriana).

Fendler blue Grass (Poa fendleriana) is pale green with an abundance of short, rather stiff, slightly rough foliage at the base, very short ligules, and narrow, dense pale panicles. Also called mutton grass. (Fig. 33).

LONG-LIGUle BLUE GRASS (Poa longiligulata) is very similar to Fendler blue grass but has smooth foliage, ligules about $1 / 4$ in. (6 mm.) long, and looser panicles.

LEIBERG BLUE GRASS (Poa leibergii) has a very dense tuft of short, smooth foliage with a few slender culms rarely over $7 \mathrm{in}$. $(17 \mathrm{~cm}$.) tall, and narrow purplish panicles. This species reaches a higher altitude than any of the others here discussed.

These six species are similar to Malpais blue grass in forage value. Pacific blue grass is more abundant than the others, but much less so than Malpais or Sandberg blue grasses. All are associated more or less. For example, the elevational range of Pacific blue grass is between 6,500 and 10,000 feet; of Nevada blue grass 4,500 and 9,000 feet; of alkali blue grass 4,000 and 9,000 feet; Leiberg blue grass 7,500 and 12,000 feet; and of Fendler blue grass and the closely related long-ligule blue grass, about 7,000 and 11,000 feet.

The forage value of these species is high but because of their relatively sparse growth they do not contribute greatly to the forage crop. Under improved grazing management these species may be expected to increase appreciably in abundance. Fendler blue grass, for example, is a highly productive plant in some localities outside of California, but like some of the others, its high palatability and rather meager seed production require that a seed crop be permitted to develop for several years in succession before the stand may be noticeably increased.

\section{Annual Blue Grasses}

5. Annual blue grass (Poa annua) is a densely tufted low-growing winter annual with soft bright green foliage and small pyramidal panicles. (Fig. 34).

Distribution and Habitat.-Annual blue grass is found from sea level to timberline. It grows in practically any soil that is not acid if the moisture is ample. It is not found on the desert. Nowhere does this 


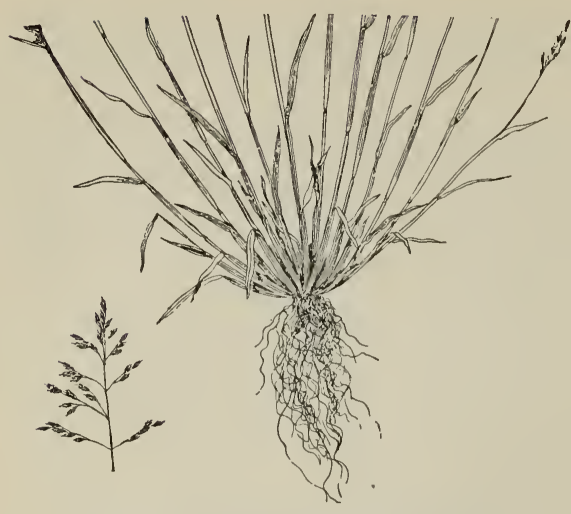

Fig. 34.-Annual blue grass (Poa annua).

species grow to the exclusion of other vegetation, but it forms a part, usually of small proportion, of the vegetation of a great many associations.

Forage Value and Reproduction.--The herbage of annual blue grass is relished by stock during its period of succulence. After the seeds are cast and the leafage dries it is grazed but little. It produces only a small amount of forage of fair quality under the best of conditions.

The seeds mature ketween the latter half of April and early June in the foothills, but in the higher elevations they sometimes do not ripen until late in September. Most annual grasses have strong seed habits, and presumably the rather large seed crop produced by annual blue grass is highly fertile.

Bigelow BLUE grass (Poa bigelovii) grows in small tufts, 10-18 in. (25-45 cm.) tall, with rough foliage and narrow panicle; HowELL BLUE Grass (Poa howellii) is 1-2 ft. (30-60 cm.) tall, with rough foliage and open panicle; and Bolander Blue grass (Poa bolanderi) 8-24 in. (20-60 $\mathrm{cm}$.) tall, with smooth foliage and open panicle about half the length of the entire plant. These three have much the same pasture value as annual blue grass, but on account of their numerous stems, which become tough rather early in the season, the leafage is not grazed closely by livestock.

\section{SALT GRASS (DISTICHLIS)}

There is but one species of SALT GRASS in California, Distichlis spicata. This is a greyish-green, low-growing perennial with strong extensively creeping rootstocks and wiry culms with numerous short, stiff, spreading blades, and narrow somewhat dense panicles of rather long smooth spikelets. The staminate and pistillate spikelets are borne on separate plants. The pistillate spikelets are a little shorter and broader than the staminate. (Fig. 35).

Distribution and Habitat.-Salt grass is an apt name, for this grass always grows in soils containing salts of various kinds-in rare instances sodium chloride or common table salt, but more commonly in soils impregnated with sodium sulphate (white alkali) and various others or 
combinations of them. It is typically a plant of brackish marshes and is common along the coast and in the interior deserts and valleys. Occasionally patches of salt grass are found at elevations of about 6,500

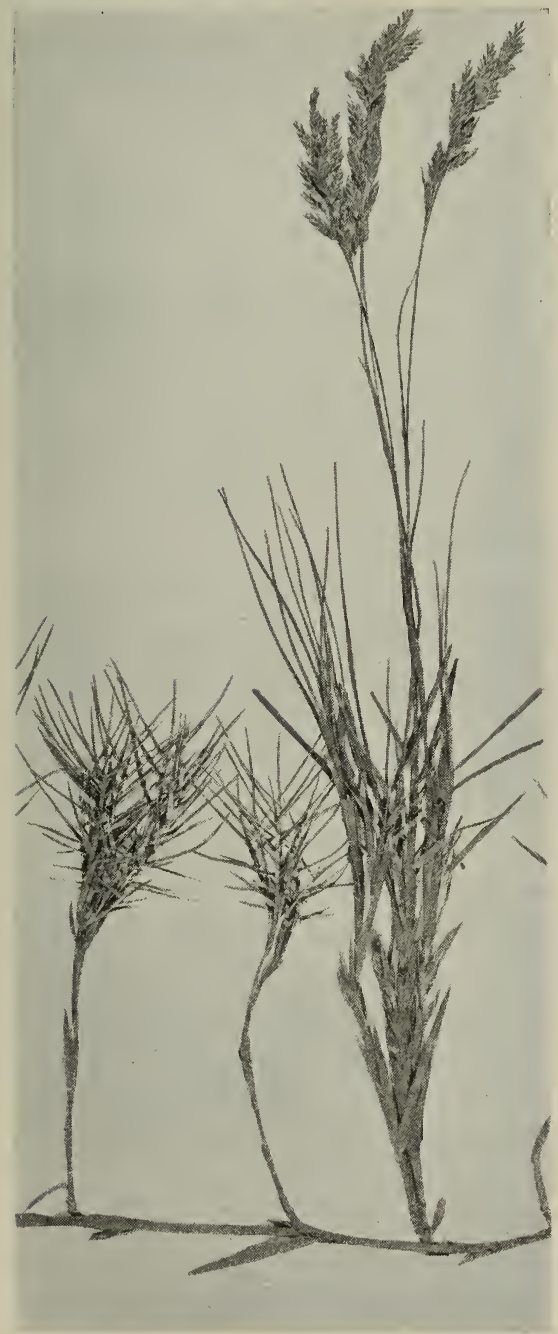

Fig. 35.-Salt grass (Distichlis'spicata).

feet. The cover is often dense, frequently forming the dominant vegetation, if not a pure stand.

Forage Value and Reproduction.-Salt grass cannot be classed as food for sheep, but cattle and horses make good use of it where more tender, succulent forage is not available. When the animals are pastured largely on alkali lands, cattlemen regard salt grass as good feed. The herbage becomes tough if allowed to grow to full length, hence it is important to keep the cover grazed rather closely. There is little danger of thinning the stand by grazing because of the tough tangle of rootstocks which send up unusually vigorous shoots at somewhat regular intervals. The seed crop, which is not usually large, matures mostly in August and September, a late period, considering the low elevations at which salt grass grows. Vegetative reproduction, by rootstocks, is unusually vigorous.

\section{MANNA GRASSES (PANICULARIA)}

These are perennials with succulent culms and foliage, and open panicles of strongly nerved spikelets. They grow in freshwater marshes or wet ground. Only one species is of importance as forage.

Nerved manna grass (Panicularia nervata) grows in clumps, sometimes forming large tussocks, the culms mostly $2-3 \mathrm{ft}$. (60-90 cm.) tall, 
the abundant foliage dark green; panicles drooping, the numerous small spikelets having a ridged appearance, because of the strong parallel nerves of the lemmas.

Distribution and Habitat.-Nerved manna grass is confined to moist or wet situations of medium elevations and is most abundant in northern California. It is tolerant of shade and often forms an important part of the vegetation of marshy woodlands.

Forage Value and Reproduction.-This grass is a "filler," for it never forms an important part of the animals' diet. It is more palatable than the average sedge or rush, however, with which it usually grows. Sheep do not graze much upon the leafage because of their dislike of wet or boggy ground. Horses and cattle graze the herbage closely. The seed ripens in July and August. It is cast as soon as it ripens, and being small it gets into the soil sufficiently for reproduction.

\section{LOVE GRASSES (ERAGROSTIS)}

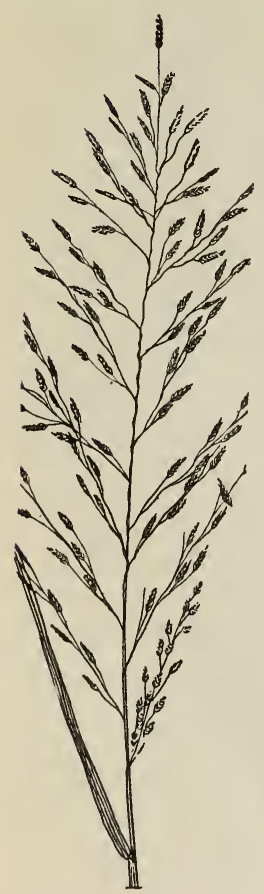

Fig. 36.-Carolina love grass (Eragrostis caroliniana).

There are only a few species of love grasses in California, none of them important forage plants. They are confined largely to valleys and foothills, and never make a dense stand. They are shallowrooted, late-growing annuals with rather scant foliage and large open panicles of small, smooth, narrow spikelets. (The common name is an old European folk name, probably referring to an ancient use in love-philtres. The botanical name is Latin for love grass.)

CAROlina lOve gRASS (Eragrostis caroliniana) grows in small tufts, the culms mostly 8 to 12 in. long, bent at the base, often weak and reclining; foliage soft; panicles mostly 4 to 6 in. long, the lead-colored spikelets lying close to the panicle branches. (Fig. 36). This is the most abundant species in the State. The best growth is in San Luis Obispo and Tulare counties. It ranges from here southward but is also found in northern California. The seed matures late in August and the foliage remains green until late in the summer. The herbage is moderately palatable but because of its sparse growth is not highly valuable in any part of its range. 
Mexican love grass (Eragrostis mexicana), a larger species with a looser panicle about half the entire height of the plant, and larger, olivegreen spikelets, is confined to southern California. Its forage value is similar to that of Carolina love grass.

\section{OAT TRIBE (AVENEAE)}

The oat tribe, because it embraces the all-important wild oats, is better known to California stockmen than any other. In addition, there are the hair grasses, June grass, trisetum grasses, and oat grasses, ${ }^{11}$ all of which produce much choice range feed. The oat tribe is characterized by 2 -several flowered spikelets, with long glumes exceeding the florets, the lemmas (except in June grass) awned from the back; spikelets in open to spikelike panicles.

\section{WILD OATS (AVENA)}

There are two species of wild oats, both introduced from Europe. They are annuals with large nodding spikelets in open panicles, the 2 or 3 florets close together, densely clothed with stiff hairs at the base, the lemma bearing a stout, bent, twisted awn from the back. (In the cultivated oat the awn is wanting or small.)

1. Wild oats (Avena fatua) is $11 / 2-4 \mathrm{ft}$. $(45-120 \mathrm{~cm}$.) tall, stooling from the base, forming tufts; foliage fairly abundant, the blades $1 / 4$ to nearly $1 / 2$ in. $(6-10 \mathrm{~mm}$.) wide; panicle large, very open, the spikelets about $1 \mathrm{in}$. (22 mm.) long, the awns $1 \frac{1}{2}-2$ in. (32-44 mm.) long; lemmas minutely 2-toothed at the tip. (Fig. 37).

Distribution and Habitat.-This species grows on many kinds of soils, such as clay loam, sandy lands, and stiff adobe. The best yields are found on moderately moist rich adobe lands, but on dry areas the cover is often conspicuous. Wild oats is a valley and foothill plant and conspicuously the dominant grass over a large part of the State's grazing grounds. It grows mostly as a winter annual, that is, the seed germinates in the autumn and growth continues through the winter, maturing early in the spring.

Forage Value and Reproduction.-On the winter ranges wild oats is by far the most important grass. Growing, as it does typically, in association with bur clover, alfilaria, various brome grasses, and many other choice forage plants, it is not only valuable in balancing the forage ration but is among the heaviest forage producers. For example,

11 The name "wild oats" applies only to plants of the genus Avena, or true wild oats, while "oat grass" is the name for the less important grasses of the genus Danthonia. 


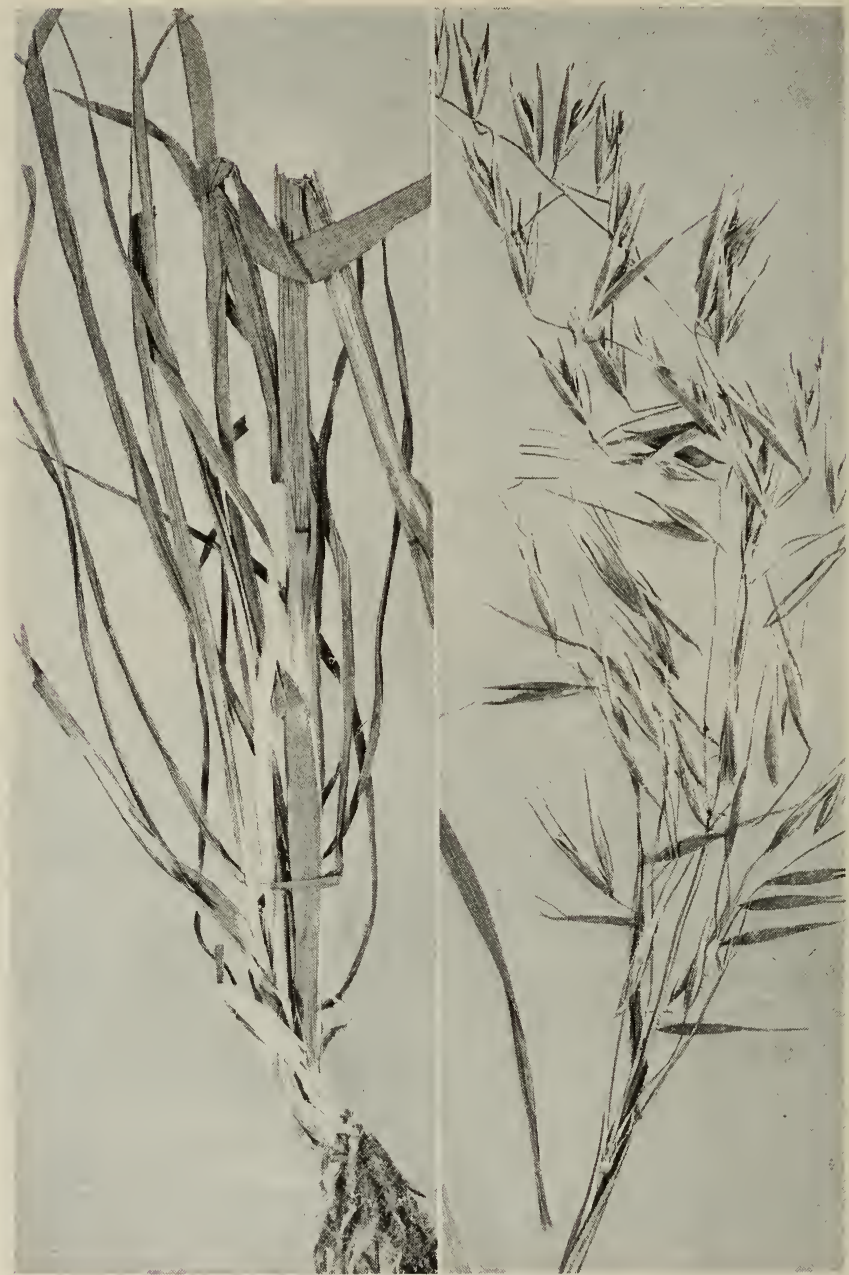

Fig. 37.-Wild oats (Avena fatua).

on good lands $11 / 2$ tons of excellent hay, purely a volunteer crop, is sometimes taken off an acre. Foraging animals are very fond of wild oat pasture and hay, but after the copious seed crop has fallen and the herbage has dried, stock do not graze it closely. With the coming of autumn rains, however, much of the herbage of the previous winter's growth is devoured with the new lush feed. The seed heads, which are very fattening, are eagerly sought by stock. The amount of good seed produced is exceptionally large. It begins to ripen in May and in the latter part of June it has mostly fallen. Because of the large seed it is 
important that the pasture be grazed after the seed is cast, for the awn does not accomplish self-planting. Light autumn grazing appears to work the seed well into the ground. Wild oats responds unusually well to deferred grazing. This would be expected because, among other things, it is an early invader in the development of the plant cover. According to the results of a preliminary study conducted in three counties, a seed crop may be expected to develop if the wild oat ranges are grazed until about the middle of March. There must be no grazing after that until the seed has fallen. Extensive additional observations must necessarily be made, however, before definite reseeding plans may be recommended. Stockmen in many parts of the State are cooperating admirably in working out the revegetation problem on the wild oat lands.

SLeNDER Wild oAts (Avena barbata) is similar to wild oats, but is usually more slender, with somewhat narrower panicles. The lemmas end in two long slender teeth. While this species is not so abundant and widely distributed as wild oats, it is a valuable forage plant. Since it grows in association with the related species the revegetational plan is the same for both.

\section{JUNE GRASSES (KOELERIA)}

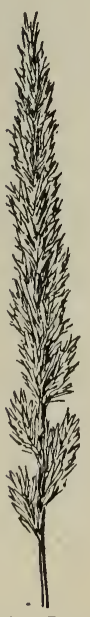

Fig. 38.-June grass (Koeleria cristata).

There is one native June grass in California, Koeler or mountain June grass (Koeleria cristata), a densely tufted perennial, resembling some species of blue grass; foliage soft, abundant; panicle narrow, dense, pale and shining, the glumes and lemmas sharppointed. (Fig. 38).

Distribution and Habitat.-June grass is most abundant in the Coast ranges and in the southern mountains, between elevations of 3,000 and 10,000 feet. It occupies well-drained soils, such as open glades or lands with scattered timber, where it often constitutes the most conspicuous and abundant herbage. Being relatively early in the succession, it is typically associated with various broad-leaved herbs like lupine, geranium, yarrow, and aster and with perennial brome grasses.

Forage Value and Reproduction.-Wherever June grass occurs plentifully it is valuable as forage. The abundant basal leafage, when young, is grazed by sheep with nearly as much relish as by cattle and horses. Until the seeds are fairly well developed the stalks are grazed by cattle and horses. The flower stalks are among 
the earliest to appear, a fact which has been used recently in determining when a range may be grazed without injury. They usually appear in May from ten days to two weeks after growth has started, a time when the forage of all species may be pastured lightly- "topped" as it is termed. The seed habits are good considering the elevations at which the plant grows.

\section{TRISETUMS (TRISETUM)}

California has five trisetums, but only one-spiked trisetum-is an important forage plant.

Description of Trisetums. - These are perennial bunch grasses with soft foliage and dense or open panicles of flat shining spikelets, the florets with a slender bent awn from the back.

SPIKED TRISETUm (Trisetum spicatum) is densely

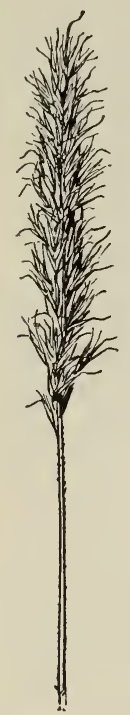

Fig. 39.-Spiked trisetum (Trisetum spicatum). tufted, $1 / 2^{-1} / 2 \mathrm{ft}$. $(15-45 \mathrm{~cm}$.) tall; the foliage soft, abundant, often whitish velvety; panicles dense, spikelike, pale or purplish. (Fig. 39).

Distribution and Habitat.-This is an alpine dweller, being confined to the high summer ranges, especially of the Sierra Nevada. It descends to 5,000 feet, but ascends beyond timber line, sometimes to the highest limits of flowering plants. It occupies medium moist to dry soils, but the stand is seldom dense. It is among the first to leaf in the spring.

Forage Value and Reproduction.-Because of its wide distribution through the State, spiked trisetum produces a large amount of forage. The herbage is relished by stock, little being left even on areas not pastured until in the autumn.

Near timberline the seed does not ripen until September or October but over most of its range the seed is cast late in August. Unfortunately the seed habits, as reported from studies in eastern Oregon, are not strong.

\section{HAIR GRASSES (AIRA)}

There are four hair grasses in California, one annual and three perennials. The pasture value of the different kinds varies widely. Moreover, they belong to different successional stages, from the earliest to the latest among herbaceous plants. By far the most abundant is tufted hair grass. Slender hair grass is second. 
Description of Hair Grasses.-These are bunch grasses with slender culms, narrow or inrolled blades and loose open or narrow panicles; spikelets not strongly flattened; florets 2 , broad at the summit, awned from the back near the base.

TuFted HaIr grass (Aira caespitosa) grows in dense tufts, $1 \frac{1}{2-3} \mathrm{ft}$. (45-90 cm.) tall, with abundant rather stiff foliage, and open panicles,

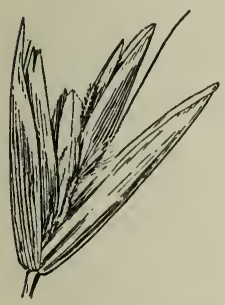

Fig. 40.-Tufted hair grass (Aira
caespitosa). the branches spikelet-bearing towards the ends; spikelets shining, the awns delicate. (Fig. 40).

Distribution and Habitat.-This attractive appearing and palatable grass is common in moist meadows and semi-marsh areas of the Sierra Nevada and other high mountains. The elevational range is between 5,000 and 10,000 feet. The closely sodded cover is sometimes so dense as to exclude most other vegetation. It is a stable type of grass and is high in the developmental stage of herbaceous plants.

Forage Value and Reproduction.-All stock graze the leafage closely, provided it is not fully developed when they are admitted. Because of the moist habitat, the leafage, if kept grazed, continues to grow throughout the summer. The plant stands much close grazing and trampling without apparent injury. Reproduction by basal shoots is vigorous. The seed crop is not generally large but it appears to germinate well. It matures late, usually in September and October.

Slender haIr grass (Aira elongata) has the appearance of an annual. It grows in small tufts, has fine foliage and long narrow panicles. It occurs throughout the State on well-drained soils, from sea level to 9,000 feet or more in elevation. Its pasture value is relatively low. One objection is that the shallow roots permit the animals to pull them out. After masticating the leaves and stalks, cattle and horses expel them, for the roots and clinging dirt remain to form the dessert to their meal. After a few such experiences stock seek a different "menu." Early in the summer the leaves become dry and no longer attract the animals. The seed crop, which is large, ripens in August.

CAlifornia hair grass (Aira holciformis) and ANNUAL HaIr GRASS (A. danthonioides), often associated with slender hair grass, are of limited forage value. California hair grass is coarse with stiff inrolled blades and narrow, rather dense, bronze-colored panicles. They occur throughout the valleys and foothills, annual hair grass of ten being associated with slender hair grass. Cattle and horses graze them to some extent but they are purely fillers. California hair grass occupies marshy areas, hence it is not always available to the animals. 


\section{OAT GRASSES (DANTHONIA)}

There are four species of oat grasses in the State. They are leafy and palatable, but being rather scarce they contribute little to the forage crop. California oat grass is among the most abundant.

Description of Oat grasses.- These are tufted, shallow-rooted perennials with leafy base; panicles small with a few rather large spikelets; glumes overtopping all the florets; lemmas 2-toothed, with a twisted bent awn from the base of the teeth. The culms readily disjoint at the lower nodes. At the base of each joint, inclosed in its sheath, is a selffertilized spikelet with grain more than twice the size of those of the terminal spikelets.

California oAt grass (Danthonia californica) is 2-3 ft. (60-90 cm.)

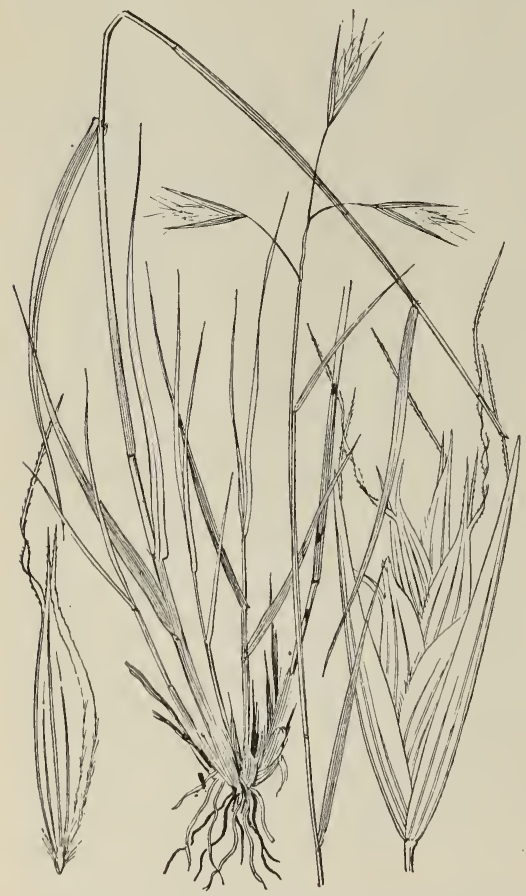

Fig. 41.-California oat grass (Danthonia californica). tall, with abundant smooth foliage; spikelets usually 3 or 4 , about $3 / 4$ in. (18 mm.) long, on spreading pedicels. (Fig. 41).

Distribution and Habitat. - It occurs sparsely in well-drained or sometimes moist soils, from sea level to about 8,000 feet, being most abundant in the Coast ranges as far south as San Luis Obispo County. The associated species are commonly brome grasses, blue grasses, and fescues. It is practically never the dominant plant.

Forage Value and Reproduction. - There is a large proportion of fine, basal leafage which is relished by stock, and grazed as closely as that of the more abundant choice blue grasses. The only drawback is that there is not enough of it, the species being nowhere abundant. The amount of seed produced is rather small. In the Bay region and in San Joaquin valley the flower stalks are produced in April, and early in June the seed is cast. Because the seed is large it must be trampled into the ground to insure good germination. 
American oAt Grass (Danthonia americana), with shorter culms and hairy foliage; FEW-FLOWERED OAT GRASS (D. unispicata), like American oat grass but smaller and having only a single spikelet; and MOUNTAIN OAT GRASS ( $D$. intermedia), with narrow panicles of several spikelets, are also leafy and relished by stock, but are likewise of scattered occurrence.

\section{REDTOP-NEEDLE GRASS-TIMOTHY TRIBE (AGROSTIDEAE)}

The redtop-needle grass-timothy tribe embraces a large number of forage grasses. The much esteemed cultivated hay plants, timothy and redtop, belong to this tribe. The needle grasses, redtops, reed grasses, muhlenbergias, dropseed grasses, and timothies are the most important groups. These grasses are characterized by 1-flowered spikelets, very small except in needle grasses and three-awn grass, pediceled in open, narrow or spikelike panicles.

\section{NEEDLE GRASSES (STIPA)}

California has fifteen species of needle grasses, most of them being grazed with relish. The stiff awns and sharp-pointed seeds of some are said to cause mechanical annoyance to livestock but seldom of a serious nature. The seeds are widely disseminated by attachment to animals. They are essentially pasture grasses but some are cut for hay. As a whole the needle grasses come in late in the revegetation of a range, their invasion and establishment following those of the brome grasses, the fescues, and the blue grasses. The most important species are: Nodding needle grass, western needle grass, desert needle grass, Thurber needle grass, small needle grass, curly-awned needle grass, and certain allied species.

Description of Needle Grasses.-They are perennial bunch grasses with simple culms, narrow or rolled blades; spikelets long and narrow with thin, pointed glumes, the florets with a needlelike point at the base and a slender, twisted, bent awn from the tip. The awns untwist when wet and twist again in drying. The sharp-pointed seeds (the mature florets) are thus screwed into the soil, effectively planting themselves.

\section{KEY TO NEEDLE GRASSES}

1a. Panicle very loose and drooping 1. S. pulchra.

1b. Panicle narrow, loose or dense, not drooping.

2a. Awns very feathery.

3. S. speciosa.

2b. Awns not feathery or minutely so.

3a. Awns minutely feathery (seen by holding panicle against the light)

2. S. occidentalis.

3b. Awns not at all feathery.

4a. Awns about $1 / 2$ in. (10 to $12 \mathrm{~mm}$.) long

4. S. columbiana.

4b. Awns 4 to 6 in. long

5. S. comata. 
1. Nodding needle grass (Stipa pulchra) grows $2-3 \mathrm{ft}$. $(60-90 \mathrm{~cm}$.) tall in dense tufts with rather rough foliage; panicles $1 / 3-1 / 2$ the entire length of the plant, conspicuously drooping; glumes purplish; awns mostly $2-3$ in. (4.5-7 cm.) long. (Fig. 42). This California species was formerly called $S$. setigera, being confused with a Mexican species.

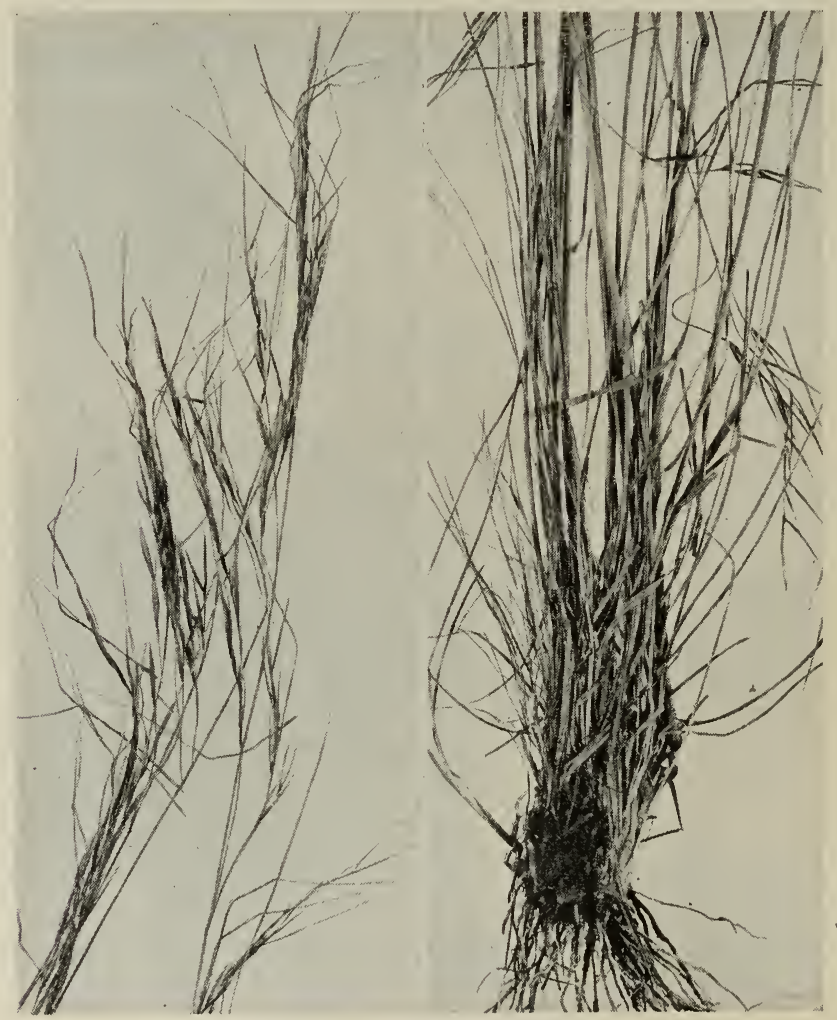

Fig. 42.-Nodding needle grass (stipa pulchra).

Distribution and Habitat.-Nodding needle grass is most abundant in the Coast Range where it inhabits the warmer slopes, open welldrained flats, and sparsely timbered areas of the foothills and valleys. It ranges in elevation from near sea level to about 5,500 feet. The cover is sometimes unusually dense, the species being dominant in favorable sites. It is among the largest of the more valuable pasture needle grasses.

Forage Value and Reproduction.-This species produces a large amount of basal herbage (leafy shoots) which is eagerly sought by stock. Being comparatively fine and succulent over a long growing period the 
leafage is relished nearly as much by sheep as by cattle and horses. It ranks high as late autumn and winter feed. As evinced by the aggressiveness and the numerous seedling plants found on conservatively grazed lands, the seed habits are strong. It matures in June. The amount of seed produced to a plant is large. Figure 43 illustrates the replacement of certain fescues, karley grasses and others by nodding needle grass. Between the tufts grow wild oats, bur clover, and alfilaria, a forage combination of superior quality. The herbage of nodding needle grass remains green long after the associated annuals have matured. Much may be expected of this valuable grass in the revegetation of the winter grazing grounds.

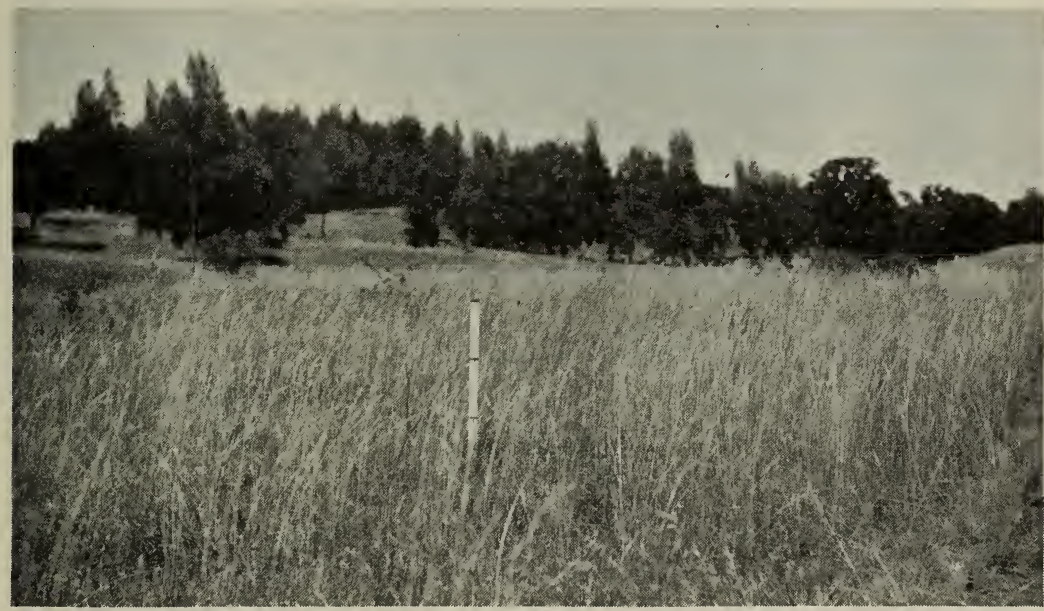

Fig. 43.-Replacement of brome grasses, fescue grasses, and other herbs by nodding needle grass (Stipa pulchra).

Small-Flowered NeEdle Grass (Stipa lepida) differs from nodding needle grass in having much smaller spikelets, the awns $1-1 \frac{3}{4}$ in. (23-42 $\mathrm{mm}$.) long.

This, too, is essentially a plant of the Coast Range, being common from the Bay region to San Diego and east to San Bernardino. It is also found in Butte County and a slender variety extends into the northern part of the State. Its range is from near sea level to the lands below the timbered type. The large amount of rather fine basal leafage is grazed with much relish throughout the season and is especially sought after the herbage of the annual vegetation has dried up. The seed is cast in June. 
2. Western needle grass (Stipa occidentalis) grows in small tufts with a mass of fine leaves at the base; culms mostly less than $15 \mathrm{in}$. (37 cm.) tall, the panicle narrow but loose, about $1 / 3$ the

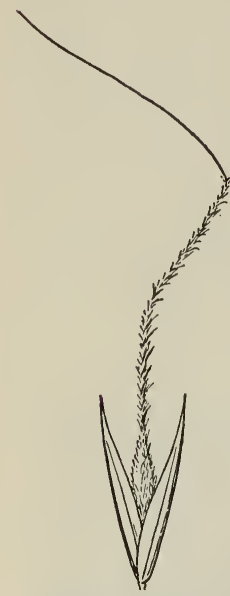

Fig. 44.-Western needle grass (Stipa occidentalis). entire height of the culm; awns $1-11 / 2$ in. $(20-30 \mathrm{~mm}$.) long. (Fig. 44).

Distribution and Habitat.-As the name occidentalis implies, this species is confined to the far West. Its range in the State is in the Sierra Nevada Mts., and it is common from the vicinity of Mt. Shasta southward, and in the southern Coast ranges between elevations of 3,000 and 10,000 feet. The stand is usually quite scattered but occasionally it forms the most conspicuous vegetation. Tests conducted on ranges in Oregon show that this species is comparatively drought enduring.

Forage Value and Reproduction.-Western needle grass begins growth early, and since the leafage is late to mature on the high ranges, being green well into September, sheep as well as cattle and horses feed upon it over a long season. Cattle and horses sometimes consume the flower stalks and seed heads until about the time the seeds are cast. Reproduction is comparatively strong but the plant is not so aggressive as nodding needle grass. The seed ripens in July and August.

ThURBer NEedLe Grass (Stipa thurberiana) resembles western needle grass, but the foliage is rough and the spikelets are a little larger. This grass is most common on the summer range from central California northward, between elevations of 4,000 and 8,000 feet. It occupies rather dry soils of the timber and brush types. The growth is scattered. The dense tufts of fine basal leafage are grazed with relish and it is unfortunate that the species is not more abundant. The seed heads are usually plump and well filled where growth is favorable. The seed is scattered during July and August.

Elmer needle Grass (Stipa elmeri) is coarser, 2-3 ft. (60-90 cm.) tall, with minutely hairy foliage and narrow panicles 6-12 in. (15-30 $\mathrm{cm}$.) long. This occurs sparingly throughout the State in timber and brush lands. The elevational range, the character and abundance of the leafage and the forage value are much the same as those of Thurber needle grass.

3. Desert needle grass (Stipa speciosa) is densely tufted, $1-11 / 2 \mathrm{ft}$. $(30-45 \mathrm{~cm}$.) tall, with tightly rolled, stiff leaves; the narrow panicles are 


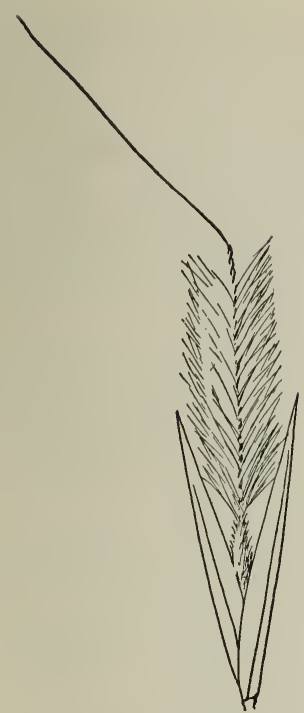

Fig. 45.-Desert ncedle grass (Stipa speciosa).

about $1 / 3$ the entire height of the culm, glistening white from the thin shining glumes and the feathery lower part of the awn. (Fig. 45).

Distribution and Habitat.-Desert needle grass grows in low, dry lands and arid hills from central California southward, being most common in the Mojave desert and the region north to Mono Lake. The elevational range is to about 6,000 feet. Because of the low carrying capacity of these lands the stand is scattered, yet it often forms the most conspicuous herbaceous vegetation.

Forage Value and Reproduction.-When young the leafage is grazed closely by all grazing animals but when mature it is grazed only by horses and cattle. In the mature plants numerous fine leaves of young basal shoots are intermingled with the old foliage, a combination which apparently attracts cattle and horses to it long after growth has ceased. The seed matures during May and June. The amount of seed produced to a plant of this species is intermediate, considering needle grasses as a whole.

4. Small needle grass (Stipa columbiana) is mostly $2-2 \frac{1}{2} \mathrm{ft}$. $(60-75$ $\mathrm{cm}$.) tall, in dense tufts of abundant leafy blades and with few culms to

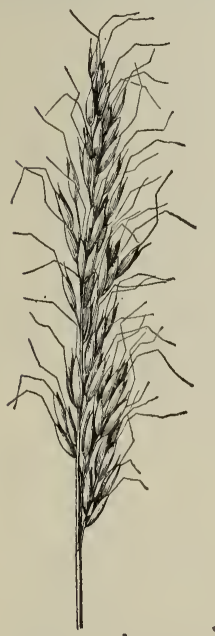

Fig. $46 .-\dot{S} \mathrm{~m}$ a $1 \mathrm{i}$ needle grass (Stipa columbiana). the tuft; blades long, flat or slightly rolled; panicles 4-8 in. (10-20 cm.) long, narrow, rather dense, purplish; spikelets about $1 / 4 \mathrm{in}$. (5-6 mm.) long, with awns about 1 in. (25 cm.) long. (Fig. 46).

Distribution and Habitat.-Small needle grass grows most commonly in the Sierra Nevada Mts. of central California between elevations of about 7,000 and 11,000 feet. It occupies open or thinly wooded, well-drained, moderately fertile soils. The growth is somewhat patchy, the species being dominant on restricted areas, but more commonly sparse. It is a drought-enduring plant.

Forage Value and Distribution.-The herbage of small needle grass is grazed closely throughout the foraging season. Because of the softer leafage sheep graze it more closely than that of many other needle grasses. The seed crop, which is of medium amount and of good viability, ripens during August and 
September. The seedlings are strong, probably because of the effective self-planting of the seed, and in the second year they are usually stocky and well-rooted.

LetTerman NeEdLe GRASs (Stipa lettermani) resembles small needle grass, but the leaf blades are inrolled and the panicles are looser. The habitat and forage value are very similar to that of small needle grass but the elevational range is lower. The stand is usually scattered. Most of the seed is dropped in August.

5. Curly-awn needle grass (Stipa comata) grows in dense clumps, the culms mostly $2-3 \mathrm{ft}$. $(60-90 \mathrm{~cm}$.) tall, the abundant basal foliage fine but rough; panicles loose, pale, $1 / 3^{-1} / 2$ the entire height of the culm; awns 4-6 in. (10-15 cm.) long, loosely curly.

Distribution and Habitat.-Curly-awn needle grass occurs throughout the State from near sea level (in the Bay region) to an elevation of about 8,000 feet. It occupies dry, often rather poor soils where it may constitute the sub-climax or somewhat permanent species. ${ }^{12}$ Usually the stand is scattered.

Forage Value and Reproduction.-As spring and late autumn forage for cattle and horses this plant ranks fairly high. Sheep eat the leafage somewhat closely from early spring to early summer. At maturity the seeds cause some annoyance to stock but not for long as the seeds drop as soon as they ripen. After the seeds are cast and the herbage is softened by the autumn rains, it is again grazed by cattle and horses. The seed crop is moderate in amount and apparently of good germination strength. It is scattered in July and August.

\section{INDIAN RICE GRASSES (ORYZOPSIS)}

There are five kinds of Indian rice grasses in California but only one, Indian mountain rice, is important on the range.

Description of Indian Rice Grasses.-They are perennial bunch grasses with narrow blades; spikelets rather broad, with thin glumes, the florets plump, pointed at base, and with a short straight awn from the tip (obscured by the hairs in Indian mountain rice).

INDIAN MOUNTAIN RICE (Oryzopsis hymenoides), sometimes called SAND GRASS, is densely tufted, the foliage nearly as long as the culms; panicle $3-6$ in. (7-15 cm.) long, at maturity equally broad, the branches very slender and widely spreading; spikelets pale and shining, the floret (seed) nearly spherical, black, densely clothed with white hairs. (Fig. 47).

${ }^{12}$ Clements, F. E. Plant indicators. Carnegie Inst., Washington. Pub. No. 242, pp. 121-124. 1920. 


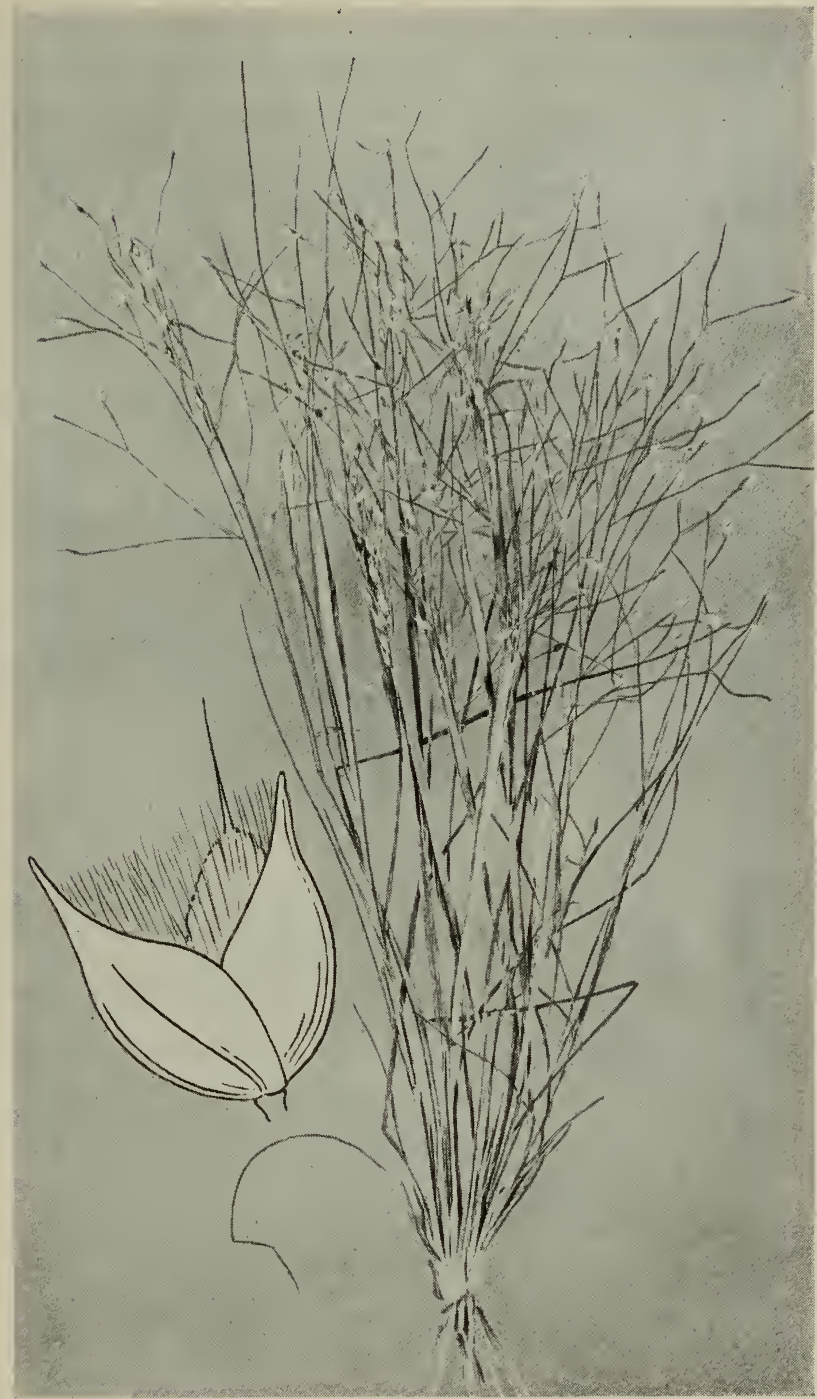

Fig. 47.-Indian mountain rice (Oryzopsis hymenoides).

Distribution and Habitat.-This is essentially a desert grass, often being the most abundant species on the Mojave desert and on semiarid lands. It occurs more or less throughout the State, however, ascending into the pine type, sometimes to 8,500 feet. It is one of the most drought-enduring grasses. 
Forage Value and Reproduction.-The forage is relished by stock until growth has ceased, when it becomes tough and unpalatable. The panicles of large, plump seeds, however, are then much sought by grazing animals. The seed production is large and, judging from the numerous seedling plants on the better sites, it is of good quality. On the desert the seed matures in May, but elsewhere in July and early in August.

\section{REDTOPS (AGROSTIS)}

There are fourteen native redtops and one widely introduced one, the common meadow redtop, in California. They are rather fine leaved plants of medium size and fair palatability to stock. Some are sod grasses occupying moist or wet soils, and some bunch grasses growing in similar or drier situations.

Description of Redtops.--These are rather leafy simple-stemmed grasses with roughish blades and open or narrow panicles of very small V-shaped spikelets, the glumes longer than the florets. The palea (see fig. 6) is wanting in most of the native species.

\section{KEY TO SPECIES}

1a. Sod grasses.

2a. Panicle pyramidal 1. A. palustris.

2b. Panicle narrower, lower branches ascending. 2. A. diegoensis. 1b. Bunch grasses. 3. A. exarata and like species.

1. Meadow redtop (Agrostis palustris formerly known as A. alba) is $1 \frac{1}{2}-3 \mathrm{ft}$. (45-90 $\mathrm{cm}$.) tall, with strong rootstocks forming a tough sod; blades $1 / 8-1 / 4$ in. (3 to $6 \mathrm{~mm}$.) wide; panicles pale or purplish-red. (Fig. 48).

Distribution and Habitat.--Introduced from Europe and escaped from cultivation, meadow redtop grows rather sparsely on the better soils from sea level to about 6,000 feet in elevation. The volunteer stand is not aggressive in California, yet in moist, rich soils stands of moderate density are sometimes seen.

Forage Value and Reproduction.-When growing with other palatable forage plants meadow redtop is closely grazed by cattle and horses especially. It is well known to stockmen as a good hay plant. It withstands heavy grazing and trampling unusually well. It reproduces by shoots from the rootstocks as well as by seed. The seed habits are strong. 


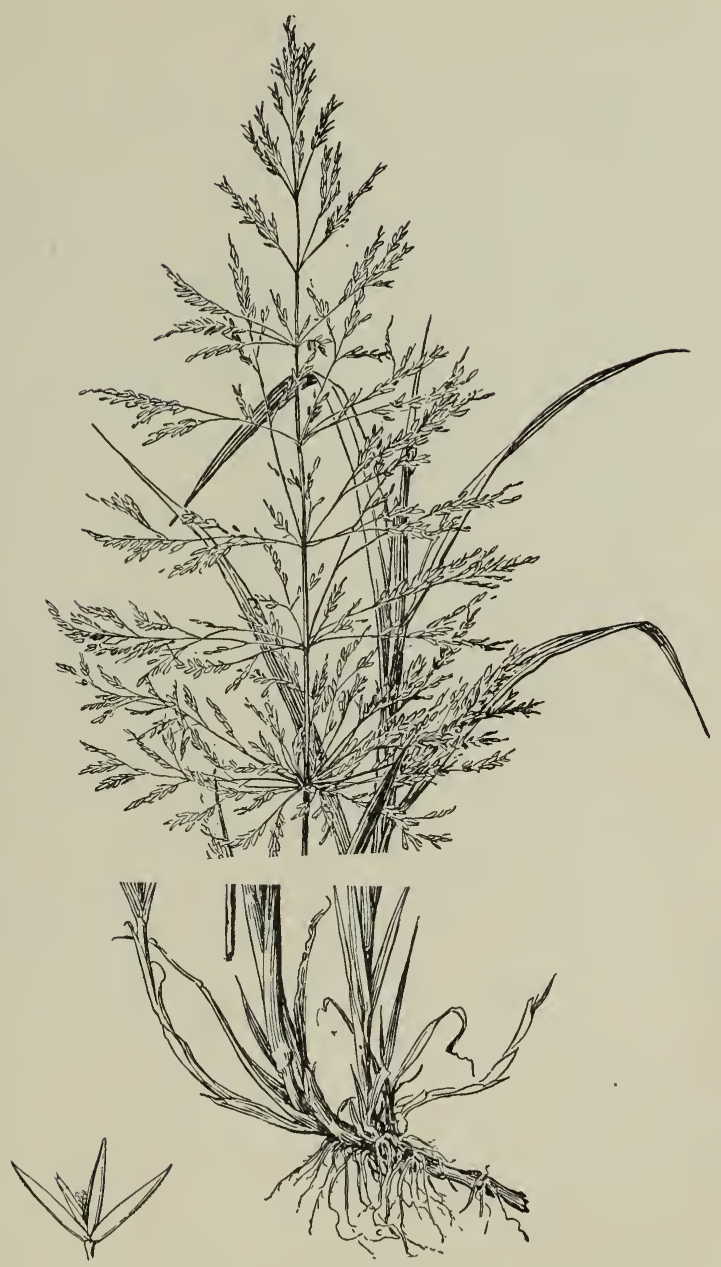

Fig. 48.-Meadow redtop (Agrostis palustris).

2. Leafy redtop (Agrostis diegoensis) is the most abundant of the native sod formers. It has finer foliage than meadow redtop and narrower panicles.

Distribution and Habitat.-This species is found in moist sites from Humboldt County, south along the coast, in the Sierra Nevada and San Jacinto mountains. The elevational range is from sea level to about 7,500 feet. The growth is rather scattered over most of its range. 
Forage Value and Reproduction.-The herbage production on a plant basis is comparatively large. Being relished by all foraging animals, well-rooted and apparently withstanding grazing well, it is unfortunate the cover is not denser. The seed ripens in August or early in September on the more elevated lands of northern California.

HALL RedTop (Agrostis hallii) grows in association with leafy redtop. It is taller, coarser and somewhat stemmy, the panicle resembling that of meadow redtop, but the florets have a tuft of soft hairs at base.

3. Western redtop (Agrostis exarata) is also a moisture-loving species but its water requirements are less exacting than those of some redtops.

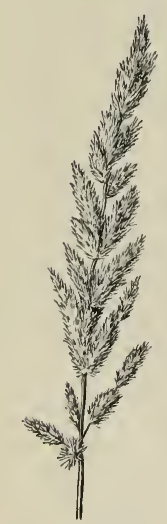

Fig. $49-$ Western $\mathrm{r}$ e d t o p (Agrostis exarata).

It is found throughout the State, being most abundant along the coast and in the mountains to about 9,000 feet. It is densely tufted, with abundant rough foliage and long, narrow, dense panicles with longpointed spikelets. (Fig. 49). This grass varies in size according to its habitat, ranging from a few inches with fine leaves to $4 \mathrm{ft}$. (120 cm.) with coarse leaves. The florets sometimes have a delicate awn on the back.

OREGON REDTOP (Agrostis oregonensis) grows in smaller bunches and has oblong open panicles. It is found in northern California where it occurs rather sparsely in moist soils between elevations of 3,000 and 8,000 feet. Its palatability is similar to that of redtops generally. The seed ripens in August.

Ross REDTop (Agrostis rossae) is a low growing stocky grass of the high Sierras. It seldom occurs below 6,000 feet. It, too, requires fairly moist soil for good development. It resembles small forms of western redtop but its foliage is mostly at the base and it has smaller spikelets, not long-pointed.

IDAHO REDTOP (Agrostis idahoensis) resembles Ross redtop in stature and habit of growth but has an open panicle. It occurs in moist meadows of the Sierra Nevada, San Bernardino, and San Jacinto mountains between 4,000 and 10,000 feet.

ThURBer REDTop (Agrostis thurberiana) with slender culms, fine, soft foliage and open panicles is found in the high Sierras where it occupies bogs and moist swales. The stand is seldom dense.

The habitat, forage value, and reproduction of these tufted redtops are representative of the genus. Because of their sparse growth they are essentially fillers. 


\section{REED GRASSES (CALAMAGROSTIS)}

The reed grasses are closely related to the redtops but are larger and most of the species grow in drier soils. There are eleven kinds in California but few are of great importance. Horses and cattle utilize reed grasses much more efficiently than sheep and goats. The herbage is generally more palatable early in the spring than at any other time. Some are bunch and some sod grasses. Three of the bunch grasses, Brewer, Pacific, and purplish reed grasses are relatively important. Three sod formers-reed pine grass, narrow-headed reed grass, and bluejoint reed grass - are seldom abundant nor are they highly palatable to all domestic foraging animals.

Description of Reed Grasses.-These are perennials, with simple, mostly tall, culms, usually harsh foliage, and open or narrow panicles; spikelets like those of the redtops but the florets hairy at the base, delicately awned from the back and with a minute hairy rachilla joint behind the palea.

\section{KEY TO SPECIES}

1a. Bunch grasses.

2a. Panicles open.

3a. Culms not over $1 \mathrm{ft}$. (30 cm.) tall 1. C. breweri.

3 b. Culms $3-41 / 2 \mathrm{ft}$. $(90-135 \mathrm{~cm}$.) tall 2. C. nutkaensis.

2b. Panicle narrow or spikelike

3. C. purpurascens.

1b. Sod grasses.

4a. Panicle narrow or spikelike.

4b. Panicle open.

4. C. rubescens and like species. 5. C. canadensis.

1. Brewer reed grass (Calamagrostis breweri) is densely tufted with a mass of fine foliage, $3-5$ in. (75-125 cm.) long at the base, slender culms and open panicles of shining purplish spikelets. (Fig. 50).

Distribution and Habitat.-Brewer reed grass grows in moist open or partly shaded sites in the Sierra Nevada mountains, between elevations of 7,000 and 12,000 feet. It seldom forms a pure stand but is sometimes the dominant species of its association.

Forage Value and Reproduction.-The leaf blades being of fine texture, abundant, and largely basal, are sought by all classes of stock during the normal summer foraging season. The palatability of the herbage is higher than that of any other reed grass. Growing, as it 


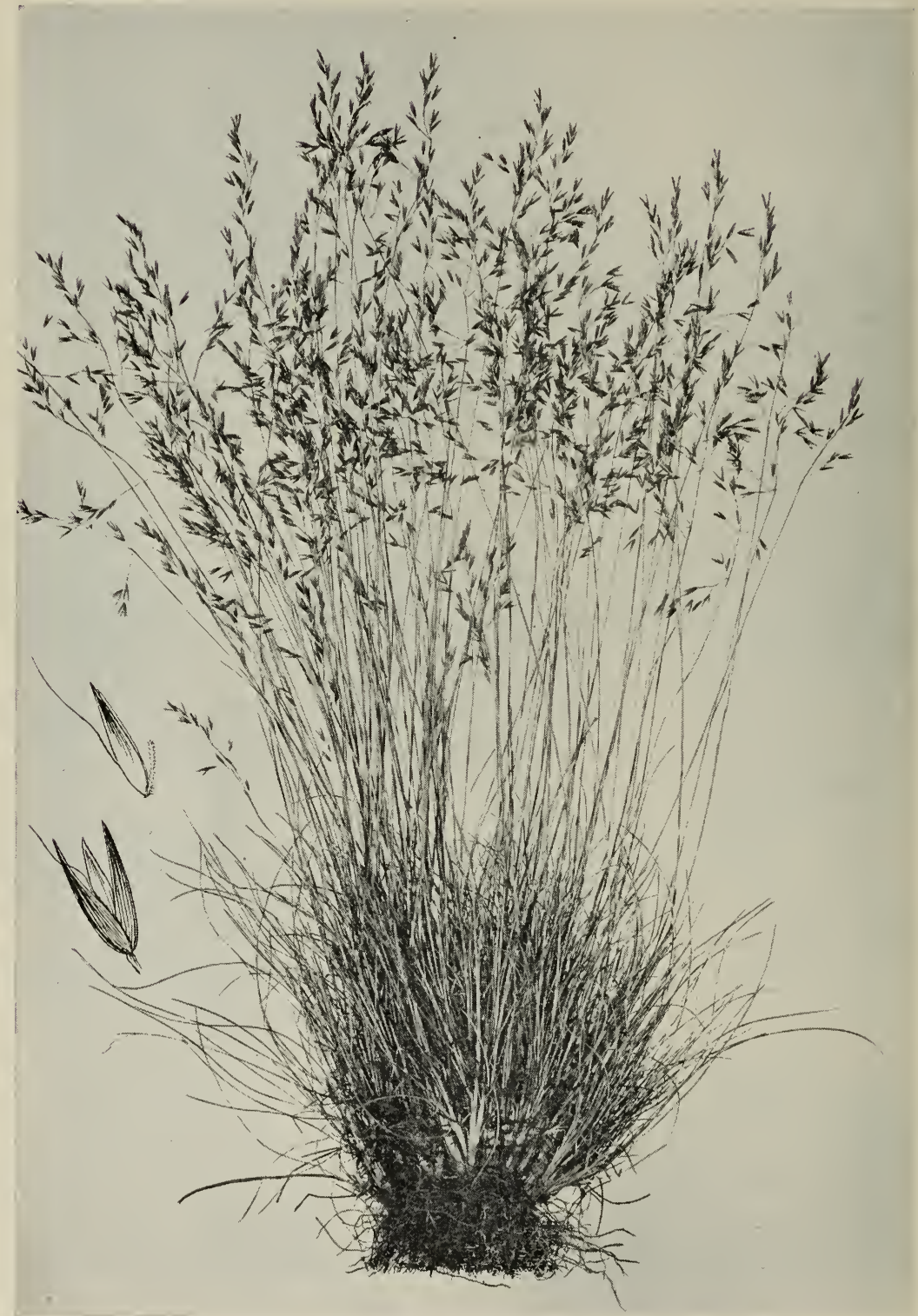

Fig. 50.-Brewer reed grass (Calamagrostis breweri).

characteristically does, in association with many other pasture plants it tends greatly to increase the value of the composite grazing type and is the most valuable species of this group. The seed ripens unevenly 
within a habitat, and, indeed, over the range generally. The seeds are scattered from early August till well into September.

2. PACIFIC REED GRASS (Calamagrostis nutkaensis) is tall, coarse and stemmy with long, harsh blades $1 / 4-3 / 8$ in. (6-9 mm.) wide; panicle 6-12 in. (15-30 cm.) long, narrow but loose.

Distribution and Habitat.-This robust plant occupies wet meadows, moist woods and brushlands along the coast from central California northward. The stand is scattered, the species almost never constituting the bulk of the herbaceous cover.

Forage Value and Reproduction.--Cattle and horses graze the herbage rather closely from the first appearance of the leaves until the seeds are well formed but not mature. As the seed approaches maturity the herbage becomes harsh and dry and is not grazed by choice until the coming of the autumn rains. Sheep take the leafage only in the spring. The seed matures in June and July. Like many other reed grasses, the seed is scattered unevenly, some not dropping for several weeks after it has ripened.

3. Purplish Reed grass (Calamagrostis purpurascens) is densely tufted, $1 \frac{1}{4}-21 / 2 \mathrm{ft}$. $(37-75 \mathrm{~cm}$.) tall; commonly purplish toward the

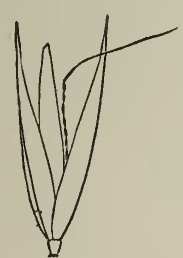

Fig. 51. - Purplish reed grass (Calamagrostis purpurascens). base; blades rough, rather stiff; panicles 3-6 in. (7-15 cm.) long, dense, pale or purplish. (Fig. 51).

Distribution and Habitat.-This grass grows sparsely in mountain meadows and elevated plateaus of the Sierra Nevada. The altitudinal range is unusually wide, being 1,000 feet at Mt. Tamalpais to 12,500 feet or more in the Sierras. Even near timberline the plants are conspicuously leafy and sometimes 2 feet high. The growth nearly everywhere is scattered.

Forage Value and Reproduction.-In early spring the leafage is grazed with relish and good results by all classes of livestock. By midsummer the herbage is harsh and is grazed with moderate relish only by cattle and horses. The fall rains bring forth a new growth of herbage which, together with the old, the animals graze somewhat closely.

4. Pine ReEd grass (Calamagrostis rubescens) grows in small tufts 2-3 ft. $(60-90 \mathrm{~cm}$.) tall, purplish at the base, producing short rootstocks which form small patches of sod; foliage softer than in most reed grasses; panicles $21 / 2-6$ in. (6-15 cm.) long, slender, pale or purplish tinged. Called "pine grass" because in the northwest it often forms a conspicuous cover in association with Western yellow pine. (Fig. 52).

Distribution and Habitat.-Pine reed grass occurs from central California northward, on well-drained lands from sea level (in the Bay 


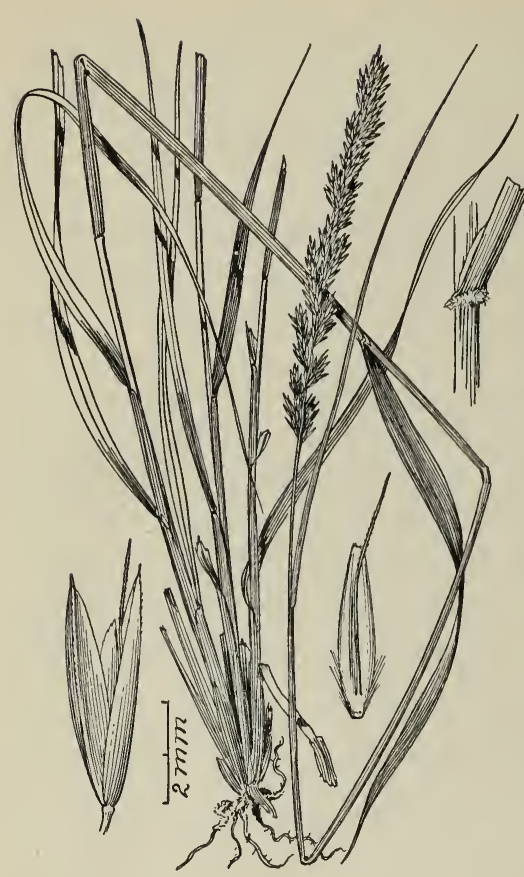

Fig. 52.- Reed pine grass (Calamagrostis
rubescens).

region) well into the lower pine belt to an elevation of about 8,000 feet. The well developed creeping rootstocks and the deep feeding roots permit it to grow remarkably well in dry, exposed situations. The stand, however, is sparse.

Forage Value and Reproduction. - Stockmen are not in agreement as to the value of pine reed grass as a range plant, presumably because of its varying palatability at different times in the season. In the spring the leafage is grazed with nearly as much relish as that of other grasses of high forage rank, and the animals do well when feeding upon it. Late in the summer it is not grazed if other good forage is available. The flower stalks are sent up over a long period, the earliest appearing in June on the lower ranges, and in July on the more elevated lands. The seed ripens between July and September. Comparatively few seed stalks are produced but according to tests made in the northwest the germination power of the seed is good.

NARROW-HEAdED REED GRASs (Calamagrostis inexpansa) is $1 \frac{1}{2-4} \mathrm{ft}$. (45-120 cm.) tall, with harsh, stiff foliage, and narrow, but not very dense, panicles; the hairs at the base of the florets are long and copious. The short, stout rootstocks form small patches of tough sod. Like the associated reed grasses, this species contributes relatively little to the

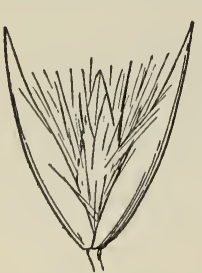

Fig. 53.-Bluejoint reed grass Calamagrostis canadensis). forage crop. It is found in moist meadows and damp open woodlands, between elevations of 5,000 and 10,000 feet, of the Sierra Nevada to Sequoia National Park. The seed ripens in August and September.

5. Bluejoint reed grass (Calamagrostis canadensis) is coarser than pine reed grass but less so than narrowheaded reed grass; the panicle is rather narrow but open and at maturity somewhat fluffy from the long hairs at the base of the florets. (Fig. 53). 
Distribution and Habitat.-Bluejoint occurs in the Sierra Nevada south to Mt. Whitney. It is strictly a wet soil grass occupying undrained meadows, swamps, and stream banks between elevations of 4,000 and 10,000 feet. Here and there it forms small patches of pure stand.

Forage Value and Reproduction.-The herbage is seldom grazed closely, but cattle and horses take most of the leafage leaving the flower stalks. The rank growth makes the herbage unattractive to sheep. The seed ripens in August. Tests made in eastern Oregon showed that the germination power of the seed is strong.

\section{WOOD REED GRASS (CINNA)}

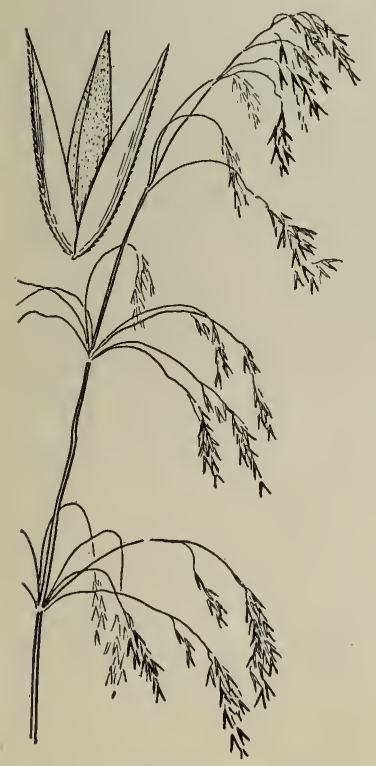

Fig. 54.-Broad-leaf reed grass (Cinna latifolia).

There is only one species, BROAD-LEAF REED GRASS (Cinna latifolia). This is a tall slender perennial with simple culms, soft foliage, the blades about $1 / 2$ in. (12 mm.) wide, and handsome drooping panicles of small, green, V-shaped spikelets; the floret is on a minute stalk and the lemma bears a short delicate awn from below the tip. (Fig. 54).

Distribution and Habitat.-This species grows at intermediate elevations, in moist or wet, usually shaded places. The stand is inclined to be patchy and somewhat dense over small areas.

Forage Value and Reproduction.-Because of its limited occurrence this species is of secondary forage value. The leafage remains green and tender throughout the summer, hence it is grazed with relish by all foraging animals. The seed habits are strong. Tests conducted in the Blue Mountains of Oregon gave seed germination of more than 75 per cent.

\section{TIMOTHIES (PHLEUM)}

The two timothies of California, alpine timothy and the introduced timothy, famous as a hay plant, are familiar to most stockmen. Alpine timothy is native. When the cultivated relative is included the genus is of great importance. 
Description of Timothies.-They are tufted perennials with simple culms, abundant foliage and dense spikelike heads or panicles; spikelets flat, the glume abruptly short-awned, the floret (seed) small and round. The spikelets are so crowded that the stout short awns point outward, making a bristly head.

Alpine timothy (Phleum alpinum) is mostly $1-1 \frac{1}{2}$

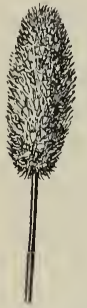

Fig. 55. - Alpine timothy (Phleum alpinum).

of livestock. Sheep would probably graze the leafage closer but for its moist habitat. The plant withstands an enormous amount of trampling. Reproduction is vigorous by means of shoots from the base. The seed ripens in August and September.

Cultivated timothy (Phleum pratense) with taller culms, somewhat bulblike at base, and long cylindrical panicles (fig. 56), grows naturally to a very limited extent on the range. It is common, however, in waste places and abandoned cultivated fields.

\section{DROPSEED GRASSES (SPOROBOLUS)}

There are three dropseed grasses in the State, one annual and two perennials. They have very small pale spikelets in large open panicles. The grain shells out of the lemma and palea at maturity, instead of remaining within them as in our other grasses. The perennials, alkali dropseed and rough-leaf dropseed, are leafy and palatable to livestock and furnish a moderate amount of forage.

Alkali dropseed (Sporobolus airoides) is pale and

Fig. 56.-Cultivated timothy (Phleum pratense).

coarse and grows usually in very large clumps, $1 \frac{1}{2}-21 / 2$

ft. $(37-45 \mathrm{~cm}$.) tall, with tough roots and abundant basal foliage; blades long, inrolled and rough toward the ends; panicle mostly about $1 / 3$ the entire height of the plant, drab-colored at first, nnming pale and open, the branches stiffly spreading. (Fig. 57). 


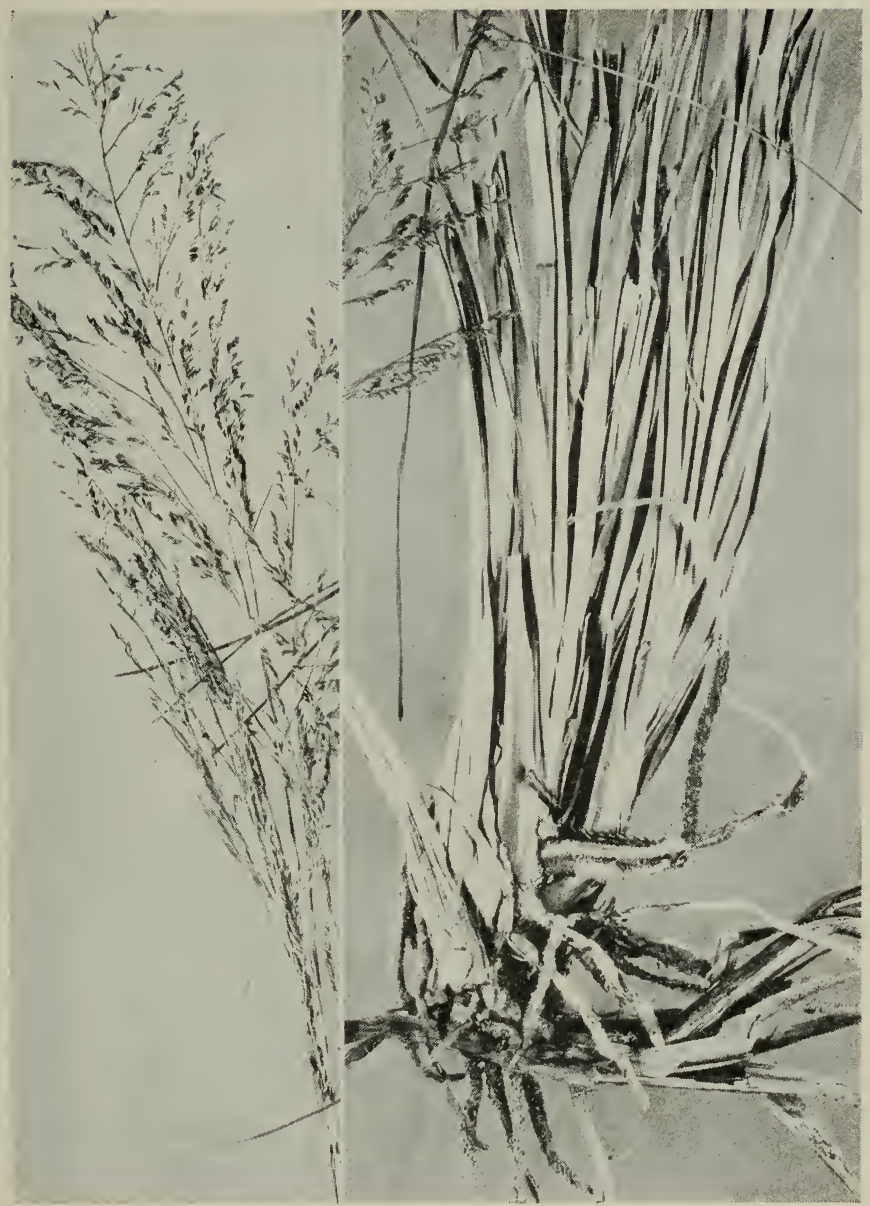

Fig. 57.-Alkali dropseed (Sporobolus airoides).

Distribution and Habitat.-Alkali dropseed, as the name implies, thrives in alkaline or saline soils. It occurs somewhat sparingly through the State, from sea level to about 4,000 feet elevation. It is among the most drought-enduring of native grasses and is often conspicuous in the southern desert. It has two types of growth, the "bunch" habit and the sod-like cover, the latter occurring only in the better sites.

Forage Value and Reproduction.-For an alkali-enduring grass this species ranks high in forage value. It is more palatable than salt grass, with which it is often associated. While the leafage is rather too coarse for efficient use by sheep, it is grazed throughout the season with good 
results by cattle and horses, especially if the first grazing occurs before the foliage becomes tough. Stockmen are inclined not to feed salt when the animals pasture on this type of feed, assuming that they do not become salt hungry. Alkali lands often do not contain common salt, therefore before discontinuing the feeding of salt one should make sure that the alkali contains the chlorine of true salt. This had best be determined by sending a small sample of the surface soil to a chemist. The seed ripens in August and Septemter. The seed habits appear to be good.

Rough-LEAVEd DRopseed (Sporobolus asperifolius) is low and spreading, with extensively creeping runners and numerous slender culms with fine foliage; panicles large and open with very fine branches, falling from the culms and rolling as tumbleweeds. This dropseed occurs in moist saline bottomlands of the valleys and foothills from Lassen County to Death Valley. The elevational range is seldom more than about 5,500 feet. It is not nearly so abundant as alkali dropseed. In palatability it is similar to salt grass. The creeping rootstocks and its characteristic occurrence on adobe soils make close grazing possible without apparent injury.

\section{MUHLENBERGIAS (MUHLENBERGIA)}

Ten muhlenbergias are found in the State but all grow so sparsely or produce so little herbage that in forage value they are fillers only. While some make a mat of tangled stems and leaves, such patches are small. The herbage and stems of some of the best species early become woody and unpalatable. Some rather unpalatable kinds have nearly disappeared from the range because of their inability to withstand trampling. The best forage species are: Porter muhlenbergia, Jones muhlenbergia, and short-leaf muhlenbergia.

Description of Muhlenbergias.-These are rather low wiry perennials, with fine foliage and very small, pointed or delicately awned spikelets in narrow or loose panicles.

KEY TO SPECIES

1a. Panicles loose, as broad as long.

1. M. porteri.

1b. Panicles narrow.

2a. Plants in tufts with basal foliage $3-6$ in. $(7-15 \mathrm{~cm}$.$) long........2. M. jonesii.$

2b. Plants forming little mats, the culms bent or creeping at base; blades short.

... M. squarrosa. 


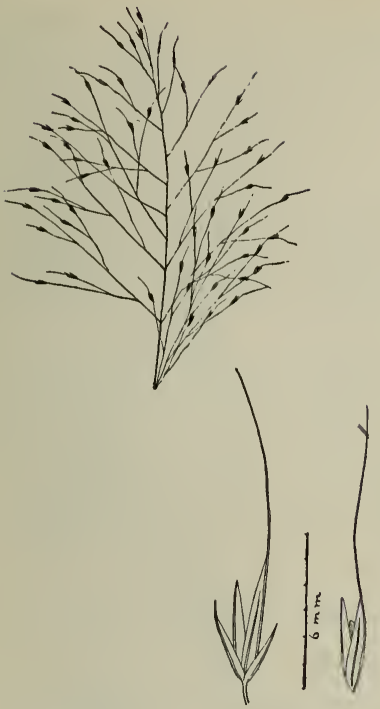

Fig. 58.-Porter muhlenbergia (Muhlenbergia porteri).

1. Porter muhlenbergia (Muhlenbergia porteri), known also as black grama and mesquite, grows in large loose masses; culms slender with numerous spreading branches; foliage fine, rather sparse; panicles at maturity about as broad as long, the spikelets on long delicate pedicels, purplish, awned. (Fig. 58).

Distribution and Habitat.-This species occurs sparsely on exposed hillsides and deserts in southern California, seldom above 7,000 feet. It is a curious-looking grass because of its half-shrub form of growth. It often forms tangled masses in association with buckbrush, oak, and other protective vegetation. The hardened branching culms, unlike most other grasses, are perennial and remain green and somewhat succulent the whole year.

Forage Value and Reproduction.-The herbage is palatable to all livestock classes, and in winter the stems are devoured by cattle and horses with moderate relish. Where no more succulent forage is available stems three to five years old are closely grazed. The seed, which is fairly abundant, ripens in July and August.

2. Jones muhlenbergia (Muhlenbergia jonesii) is densely tufted, with a mass of rough loosely curled foliage at the base; culms slender, $1-1 \frac{1}{2} \mathrm{ft}$. (30-45 cm.) tall; panicles narrow, spikelets pointed or awn-tipped. (Fig. 59).

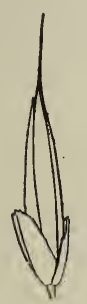

Fig. $59 .-\mathrm{J}$ o $\mathrm{n}$ e $\mathrm{s}$ muhlenbergia (Muhlenbergia jonesii).

Distribution and Habitat.-This species occurs only in northern California in meadows and exposed lands of intermediate elevations. The stand is sparse.

Forage Value and Reproduction.-The herbage being fine and abundant, stock graze it closely, sheep preferring it to that of coarser grasses. Unfortunately the species is never abundant over large areas. The seed habits are not very strong. The seed mostly ripens and drops in August.

Mountain muhlenbergra (Muhlenbergia montana) is similar to Jones muhlenbergia but is taller and the spikelets have loosely curled awns $1 / 2^{-3} / 4$ in. (10-18 mm.) long. This species has an abundance of comparatively coarse basal leafage $3-5$ in. ( $7-12 \mathrm{~cm}$.) long. It grows 
thinly on rather dry, often shallow soils between elevations of 5,000 and 9,000 feet in the Sierra Nevada and in the region of Lake Tahoe. The herbage is grazed by all livestock but is not highly relished late in the season.

3. Short-leaved muhlenbergia (Muhlenbergia squarrosa) grows in tough bunches or mats with flat spreading culms and short blades;

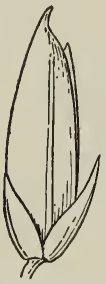

Fig. 60. - Shortleaved muhlenbergia (Muhlenbergia squarrosa.) panicles narrow, closely flowered; spikelets awnless. (Fig. 60).

Distribution and Habitat.-This mountain plant is most abundant in northern California, the region of Lake Tahoe being about the center of distribution. It is most common on thin, inferior soils between elevations of 7,000 and 10,000 feet. The stand is often patchy and closely matted.

Forage Value and Reproduction.-This species is grazed closely only early in the season, for as it approaches maturity the leafage becomes tough and unpalatable. Moreover, the stemminess and scant herbage do not attract stock, especially cattle and horses. The seed ripens in August and early September, only a small amount, apparently, being produced.

Slender muhlenbergia (Muhlenbergia filiformis) is similar to shortleaved muhlenbergia but it is smaller and not so wiry and tough and makes softer mats with finer foliage. It is also a mountain plant, occurring scatteringly in meadows and protected glades between elevations of 6,000 and 10,000 feet, from Siskiyou County south, in the Sierra Nevada, San Bernardino, and San Jacinto mountains. The plants are very stemmy (sometimes 50 or more culms to a plant), hence the short, sparse leafage is not very attractive to stock. Sheep, however, graze it with advantage.

Aparajo muhlenbergia (Muhlenbergia repens) is low, extensively creeping and freely branching with short fine blades and small narrow panicles. This little grass is found only in the deserts of Inyo County (Funeral Mts.). In moist situations dense patches are formed. The flower stalks sometimes appear in December and January but the seed seldom ripens until April. The herbage is palatable to stock but the species is too scarce to be of importance.

\section{DEER GRASS (EPICAMPES)}

Only one DEER Grass (Epicampes rigens) is found in California. It is a coarse bunch grass $3-41 / 2 \mathrm{ft}$. (90-135 cm.) tall, with very tough 


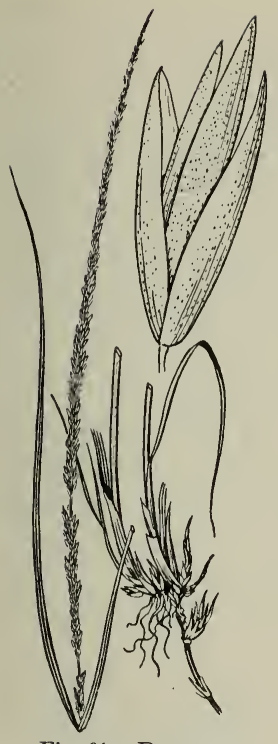

Fig. 61.-Deer grass (Epicampes rigens).

roots and long rough blades; culms simple; panicles long, slender, and dense; spikelets small, the glumes shorter than the floret; lemma 3nerved. (Fig. 61).

Distribution and Habitat.-Deer grass occupies well-drained, open ground or thinly timbered areas of the valleys and foothills, from Butte County south in the Santa Barbara and San Jacinto mountains. The elevational range is up to about 6,500 feet. Where ample moisture is available early in the season a fairly dense cover is formed.

Forage Value and Reproduction.-Range stock relish the herbage most before the numerous coarse flower stalks are fully developed. After seed maturity the animals seldom graze deer grass closely if other good feed is available. The plant must be classed with the fillers. The seed ripens in July and August. The seed habits appear to be strong.

\section{THREE-AWN GRASSES (ARISTIDA)}

There are nine three-awn grasses in California but only three species are at all common on the pasture lands. They are sometimes collectively called poverty grass because of their low value as forage and because they often grow on poor soils. They readily invade depleted ranges and, being early in the succession, they are, in turn, sooner or later replaced by species of the more permanent types.

The three-awns are perennial or annual bunch grasses with wiry culms, narrow or inrolled blades and rather long spikelets; glumes narrow; florets with a needle-like base and a 3-pronged awn, the prongs rough and widely spreading. The ripe floret (the seeds) cause mechanical injury to stock in the same way as the seeds of certain brome grasses. (See page 27.)

The more common pasture species are spreading three-awn, purplish three-awn, and six-weeks three-awn. They are valley and low foothill plants of southern California, occurring from sea level to the conifer belt. In early spring and late autumn their herbage is grazed with much the same relish as that of the barley grasses, and chemical analyses would indicate that their nutritive qualities are similar. 
Spreading three-Awn (Aristida divaricata) is a densely tufted perennial having large panicles with stiffly spreading branches. It produces more herbage to a plant than the others. Also it is less stemmy than some. It is common on the warmer slopes where the scattered tufts are large'and well-rooted. The seed ripens in May and June.

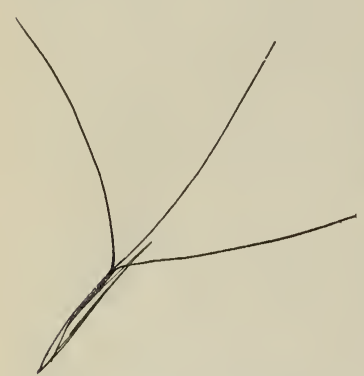

Fig. 62.-Purplish three-awn grass (Aristida purpurea).

Purplish three-awn grass (Aristida purpurea) is a tufted perennial with scant foliage and a loose narrow panicle. (Fig. 62). It occupies the plains and desert, being rather common in the vicinity of The Needles. It probably never ascends beyond the chaparral type of vegetation. The herbage becomes harsh and dry early in May after which it is grazed but little. The seed matures mostly in May.

Six-Weeks three-Awn grass (Aristida adscensionis) is a stemmy, tufted annual of nearly the same distribution and elevational range as that of purplish three-awn. On the Mojave desert it occupies inferior soils where little other vegetation grows. On the ranges of potentially higher carrying capacity it indicates that the better perennial forage plants have been destroyed.

\section{WHEAT GRASS AND BARLEY GRASS TRIBE (HORDEAE)}

The wheat-barley grass tribe embraces only four genera of much consequence on the range. Three of these genera-the wheat grasses, rye grasses, and old world rye grasses, yield herbage which is grazed with good results throughout the season by all foraging

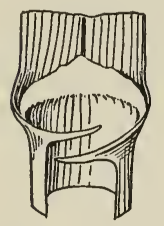

Fig. 63.-Claws of sheath in barley grass tribe. animals. The fourth, barley grasses, because of their numerous stiff awns, at maturity are injurious to livestock.

The wheat-barley grass tribe may be recognized by the rather large spikelets sessile on opposite sides of a simple axis, the glumes persistent, the florets falling at maturity, or, in barley grasses, the axis disjointing with a spikelet persistent on each joint. At the summit of the sheath in all these grasses there is a pair of little claws. (Fig. 63). 


\section{WHEAT GRASSES (AGROPYRON)}

Eleven species of wheat grasses occur in California, but only four, all bunch grasses, are of importance on the range. ${ }^{13}$ They are: slender wheat grass, bearded whẹt grass, Pringle wheat grass, blue-bunch wheat grass, their relative importance being in the order given.

Wheat grasses are rather coarse-stemmed, yet few if any grasses are grazed with more relish by all livestock. Their herbage, however, is used with most advantage by cattle and horses, especially late in the season. They are most abundant in northern California.

The wheat grasses are among the highest in the successional development of the herbaceous cover. This is because they require a fertile soil in which to complete their cycle of growth. Most wheat grasses are rather tolerant to alkali.

Description of Wheat Grasses.-These are perennials with simple culms, fairly abundant rather coarse foliage, and upright spikes, the several-flowered spikelets placed flatwise on the axis.

\section{KEY TO SPECIES}

1a. Spikelets awnless or awn-tipped

1. A. tenerum.

1b. Spikelets long-awned.

2a. Awns straight or nearly so.

2. A. caninum.

2b. Awns spreading at maturity.

3a. Spikes rather thick, the awns $3 / 4-1$ in. (18-24 mm.) long, not abruptly spreading.

3. A. pringlei.

3b. Spikes slender, the awns $1 / 2-3 / 4$ in. (12-18 mm.) long, abruptly spreading.

4. A. spicatum.

1. Slender wheat grass (Agropyron tenerum) has leafy upright culms $2-4 \mathrm{ft}$. (60-120 cm.) tall, purplish at base, the blades often $1 / 4 \mathrm{in}$. (6 mm.) wide, flat or with inrolled margins, and narrow spikes 4 to 6 in. (10-15 cm.) long. (Fig. 64). The foliage and especially the spike, is often bluish tinged. The spikelets, notably in plants of higher altitudes, sometimes bend slightly to one side, making the spike unsymmetrical.

Distribution and Habitat.-This species, found in open woods, rocky exposed hillsides, upland plains, and moist meadows between elevations of 3,000 and 10,000 feet, is California's most abundant and valuable

${ }^{13}$ Stockmen of the Rocky Mountain region consider the wheat grasses as among the most abundant and important of forage plants. California ranges probably support less wheat grass herbage than those of any other important far western range State. 


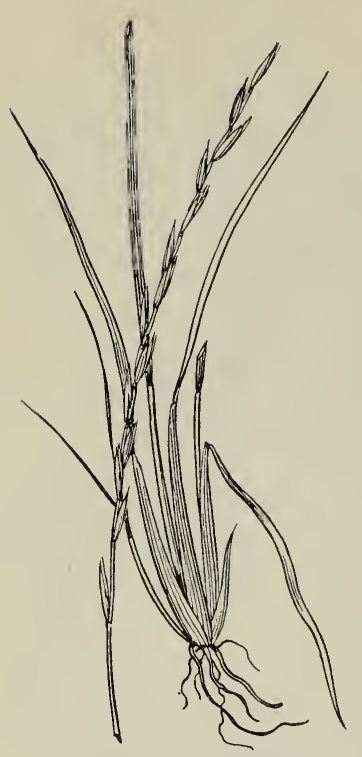

Fig. 64.-Slender wheat grass (Agropyron tenerum).

wheat grass. It is most abundant in the region of Mt. Shasta, in the Sierra Nevada, and the southern mountains. It grows on lands that contain some alkali but it is not as alkalienduring as blue-bunch wheat grass.

Forage Value and Reproduction.-Slender wheat grass furnishes choice feed for all grazing animals. Sheep graze the young herbage, which remains tender until the flower stalks are well formed, nearly as closely as that of the blue grasses and fescues, the leafage of which is finer. Horses and cattle consume the entire plant until the seeds fall, when the seed stalks are left. As winter forage it is second to none, for it cures well and seems to retain its high nutritive qualities. Slender wheat grass produces an exceptionally large and fertile seed crop. Because of this and the fact that the herbage furnishes excellent pasturage, many attempts have been made to domesticate the plant. Under irrigation a good yield is produced but the cover is seldom long-lived. Moreover, the yield is usually smaller than that of cultivated plants that do not grow in bunches. The period of maturing seed is from late July until early September. The flower stalks appear comparatively late in the season. Seed may be purchased from most seed firms.

2. Bearded wheat grass (Agropyron caninum) is $2 \frac{1}{2}-4 \mathrm{ft}$. $(45-120$ $\mathrm{cm}$.) tall, the bunches commonly less dense than in slender wheat grass,

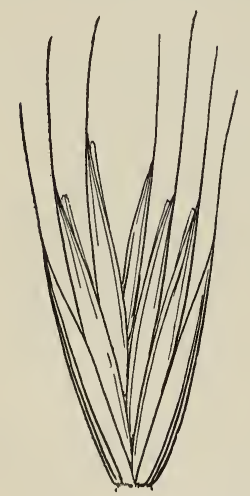

Fig. 65.-Bearded wheat grass Agropyron caninum). the culms curved at the base; foliage somewhat softer, the blades about $1 / 4$ in. $(5-6 \mathrm{~mm}$. $)$ wide; spike "bearded," the awns $1 / 2^{-3 / 4}$ in. (12-18 mm.) long. (Fig. 65).

Distribution and Habitat.-Bearded wheat grass prefers moderately moist meadows but is found also on exposed, dry situations where good stands are sometimes produced. The range in elevation is between about 3,500 and 9,500 feet, but the best growth is at intermediate altitudes. The most forage is produced in the Sierra Nevada, southern, and Santa Lucia mountains.

Forage Value and Reproduction.-Because of the awns which either protect the seed heads from being 
grazed or cause the animals some distress if the heads are eaten, the best pasturage is obtained before the seeds are well developed. Sheep have not been observed to devour many of the mature heads. Early in the season an abundance of basal leafage is produced which livestock greatly relish. While the awns are not very long or stiff stockmen have found that the mature heads of bearded wheat grass in hay are objectionable, especially for sheep. The seed crop, which matures between July and September, is fairly large and of good germination strength. Generally the seed is dropped unevenly. Reproduction is unusually good under favorable conditions where plants are allowed to mature seed. Presumably the unpalatability of the seed heads favors reproduction.

3. Pringle wheat grass (Agropyron pringlei) grows in rather loose tufts, the culms bent at the base, mostly $1-1 \frac{1}{2} \mathrm{ft}$. $(30-45 \mathrm{~cm}$.) tall; leaves smooth, rather scant; heads 2-4 in. long, the spikelets rather broad and loose, the awns somewhat curly.

Distribution and Habitat.-Pringle wheat grass is important as a pasture plant chiefly in the Sierra Nevada where it occurs between 7,000 and 10,500 feet. The best growth is attained in meadows between 8,000 and 9,000 feet, though it sometimes makes fair stands, also, on rocky outcrops. The species almost always grows sparsely.

Forage Value and Reproduction.-The herbage is palatable to all

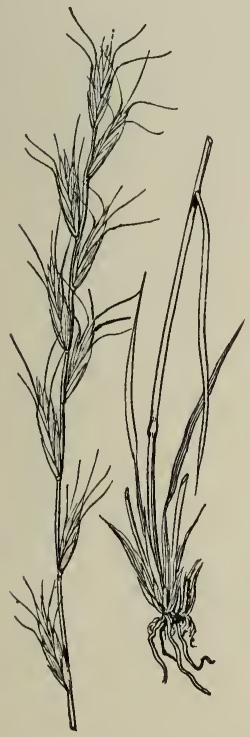

Fig. 66.-Blue bunch wheat grass (Agropyron spicatum). classes of livestock, but it grows too sparsely to be of very great value. Moreover, it occupies semiscab or rocky lands and gravel slides which are largely inaccessible to grazing animals. The seed crop ripens in August and September.

4. Blue-bunch wheat grass (Agropyron spicatum) is taller and more slender than Pringle wheat grass and grows in denser tufts; heads very slender, the spikelets narrow, the awns at maturity horizontally spreading. (Fig. 66).

Distribution and Habitat.-This species is found in the foothills and low mountains in northern California. It is typical of glades and exposed sites and thrives in soils of low water content.

Forage Value and Reproduction.-Everywhere blue-bunch wheat grass is grazed closely by foraging animals but, unfortunately, it produces so little forage as to be relatively unimportant. This statement would be surprising to stockmen of Washington and Oregon where blue-bunch wheat grass in 
many sections occupies great areas, and furnishes most of the feed. As a fall, spring, and winter feed it is preeminent. When the fall rains come on, usually in September, blue bunch wheat grass is awakened to growth, and for two months or more, according to the altitude and physiography, continues its activities. This tender and succulent herbage is ravenously consumed by all classes of stock in the fall as well as during the winter and spring. About the middle of June on the lower areas, however, the foliage becomes somewhat tough and unpalatable and ceases to be of high value for forage. Blue-bunch wheat grass has been tried extensively under cultivation, but with indifferent success. Because of convenience in handling, the awnless form (Agropyron inerme) has been used most.

\section{RYE GRASSES (ELYMUS)}

There are seven rye grasses in the State, of which one is an introduced weedy annual of no forage value and six are native perennials. Considering the entire western range the rye grasses are much less important as pasture plants than are the wheat grasses. Smooth wild rye grass, however, because of its abundance and palatability, is probably as valuable on the range as slender wheat grass, the most important of the wheat grasses. Alkali rye grass is second in importance, followed by Canada wild rye grass, and giant rye grass. The rye grasses are high in the development of herbaceous range vegetation.

Description of Rye Grasses.-Rye grasses of forage value are rather coarse perennials, with tall simple culms and fairly abundant foliage; the several-flowered spikelets are borne, 2-4 together, the clusters overlapping and hiding the axis.

\section{KEY TO SPECIES}

1a. Spikelets conspicuously awned.

2a. Spikes slender, the awns straight.

1. E. glaucus.

2b. Spikes thick and nodding, the awns curved 3. E. canadensis. 1b. Spikelets awnless or minutely awned.

3a. Sod grass; spikes slender.

2. E. triticoides.

3b. Bunch grass; spikes thick. ... E. condensatus.

1. Smooth wild rye grass (Elymus glaucus) grows in rather small bunches, the culms mostly $3-5 \mathrm{ft}$. (90-150 cm.) tall; foliage smooth or nearly so, the blades very long, commonly $1 / 4^{-1} / 2$ in. (5-12 mm.) wide, usually flat; spikes $3-8$ in. (7.5-20 cm.) long, the awns $1 / 2-1$ in. (12-24 


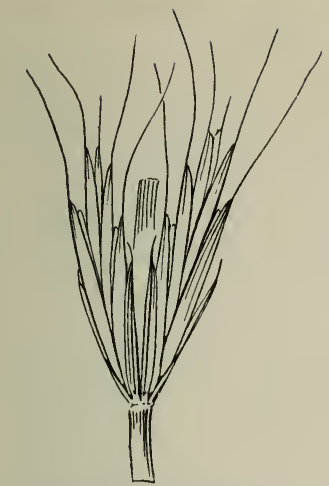

Fig. 67.-Smooth wild rye grass (Elymus glaucus).

mm.) long. (Fig. 67). This species is variable in width of blade, size of spike, and length of awns.

Distribution and Habitat.-Smooth wild rye grass occurs throughout the State, from near sea level to an elevation of 10,000 feet or more. It occupies dry to moist woodlands, open parks, and dry hillsides. On long protected nonirrigated lands smooth wild rye grass is often the most abundant and conspicuous plant. Its habit of growth varies widely according to the environment. On rich, moist soils it may grow dense, 6 feet tall, the stems being coarse and leafy. In less fertile and drier areas, it may be low of stature, with but little leafage, and the stand may be much scattered. It probably never makes a pure stand.

Forage Value and Reproduction.-Horses and cattle graze the leafage with relish and, early in the season, a portion of the stems. Sheep graze the plant with advantage early in the season but later, because it is less relished, they trample or otherwise destroy much of it. The seed heads are eaten sparingly by horses but they are mostly beyond the reach of sheep. Smooth wild rye grass produces a large amount of seed of good germination power. In the foothills and valleys, as for example, in Shasta County, the seed ripens early in July, whereas on the high summer range it does not mature until late in August. The seed drops soon after ripening. Under deferred grazing smooth wild rye grass is sure to increase appreciably on the winter ranges. Growing in association with wild oats, needle grasses, brome grasses, and bur clover, as it does, smooth wild rye grass is a valuable feed.

2. Alkali rye grass (Elymus triticoides) has long running rootstocks and forms a tough sod; culms mostly $3-4 \mathrm{ft}$. (90-120 cm.) tall, with long rather stiff blades and greenish drab-colored spikes tapering to the tip.

Distribution and Habitat.-Alkali rye grass is essentially a plant of moist bottomlands and slightly alkaline or brackish flats, but it occurs also on mountain slopes and in open timber, reaching an elevation of 10,000 feet. The best stands are in southern California, though even there it practically never forms a pure cover.

Forage Value and Reproduction.-The forage of alkali rye grass is utilized with most advantage by cattle and horses. At best, however, it is of secondary pasture value. The seed crop ripens in July on the 
lower lands in the southern parts, and in August and September in the mountains. The seed habits appear to be moderately strong.

3. Canada wild rye grass (Elymus canadensis) grows in dense clumps, with abundant coarse grayish foliage and dense nodding spikes, the awns somewhat curled and spreading at maturity.

Distribution and Habitat.-This species occurs from sea level to elevations which favor the growth of yellow pine and other conifers of the Transition, or intermediate life zone.

Forage Value and Reproduction.-The flower stalks appear during May and July and the seed ripens between July and September. A large seed crop is produced under favorable conditions. When fully developed the leafage is coarse and rough, hence is of much less value than early in the season. After the autumn and winter rains cattle and horses graze the softened leafage with good results.

4. Giant rye grass (Elymus condensatus) is a taller coarser plant with short rootstocks, forming large tussocks; the foliage is grayish,

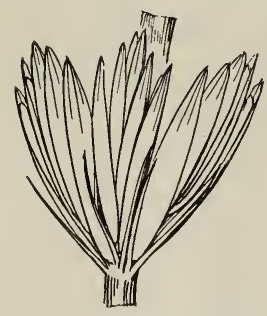

Fig. 68.-Giant rye grass (Elymus condensatus). harsh, and stiff; spikes dense, sometimes $3 / 4$ in. (18 mm.) thick. (Fig. 68).

Distribution and Habitat.-Giant rye grass grows in dry open situations throughout the State, from sand dunes near sea level to 9,800 feet, most abundantly in the Coast ranges.

Forage Value and Reproduction.-Horses and cattle graze the leafage with moderate relish except in the autumn before the advent of the rains. Horses are especially fond of the seed heads.

\section{OLD WORLD RYE GRASSES (LOLIUM)}

There are three old world rye grasses in California, introduced from Europe. Two are valuable short-lived perennials which have escaped from cultivation and are common in the interior valley and on foothill ranges of the coast. The other species (Lolium temulentum), often called darnel, is an annual from the Mediterranean region. It is the tares which the enemy sowed among the wheat in the parable of Scripture, indicating that it was a common weed in wheat fields in Palestine.

Description of Old World Rye Grasses.-These are rather slender upright grasses with soft bright green foliage and flat spikes, the spikelets set edgewise on the axis.

ITALIAN RYE GRASS (Lolium multiflorum) is usually $1 \frac{1}{2}-2 \mathrm{ft}$. (45-60 cm.) tall, and has awned spikelets. (Fig. 69). Perennial rye grass (Lolium perenne) is a smaller plant with awnless spikelets. Italian rye grass is the more valuable species because of its much greater 


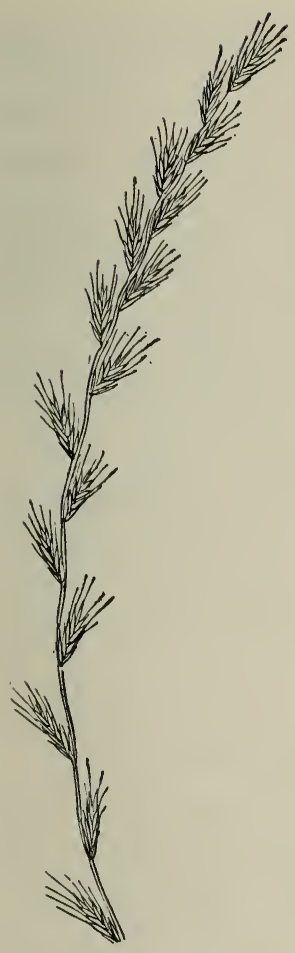

Fig. 69.--Italian rye grass (Lolium multiflorum).

abundance. Both are highly palatable to livestock. Attempts have been made to extend these grasses on the range, but without much success because they require deep rich soil and abundant moisture. Moreover, they need a moderately long and warm growing season in which to produce seed and complete their growth cycle, and are therefore not suited to seeding on high mountain ranges. Under favorable conditions the amount of good seed produced is large. It ripens in July and August.

\section{BARLEY GRASSES (HORDEUM)}

There are seven species in California, four native (three perennials and one annual), and three introduced annuals. All have bristly spikes which break up at maturity, the joint of the axis forming a sharp point below the attached spikelet. The glumes of the three spikelets look like a ring of bristles below the single fertile floret.

While barley grasses furnish a good deal of forage of fair quality early in the season, they are seriously objectionable on the range when headed out because of the injury done to grazing animals by the stiff, sharply barbed awns. MEAdOW BARLEY GRASS (Hordeum nodosum), a perennial with short fine awns (fig. 70 ), is the only one that does not cause

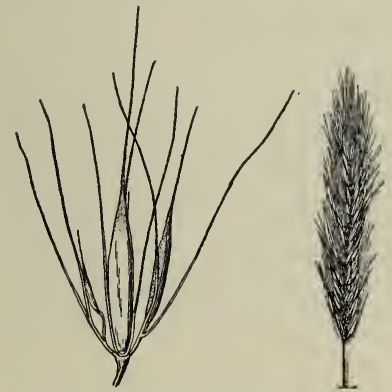

Fig. 70.-Spike and single joint of meadow barley grass (Hordeum nodosum). annoyance to livestock. The annuals are most abundant in the valleys and foothills.

WALL BARLEY GRASS (Hordeum murinum) an in-

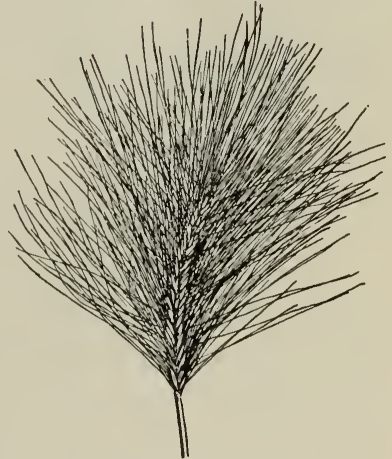

Fig. 71.-Squirrel-tail barley grass (Hordeum jubatum) troduced annual with flattish heads, $1-2$ in. (24-48 mm.) wide, the awns $1-1 \frac{1}{2}$ in. (24-36 $\mathrm{mm}$.) long, is the commonest and most troublesome species. SQUIRREL-TAIL BARLEY 
GRAss (Hordeum jubatum), a native perennial bunch grass, with pale fluffy bristly heads, the slender awns $2-2.5$ in. (5-7 cm.) long (fig. 71) is next in abundance.

Both wall barley grass and squirrel-tail barley grass inhabit range lands as well as cultivated fields. They are grazed with good results until the heads are formed, after which the awns cause serious annoyance to stock, working between the teeth, in the tongue, throat, eyes, and skin. Where the mature heads of barley grasses are abundant in hay, stockmen feed the hay with safety only during wet weather, scattering it on the ground. The animals are not permitted to eat the hay until several hours after it has been scattered, when the awns have become soft and are eaten without serious after-effects. It is best, however, to cut barley-infested hay before the heads are formed. The barley grasses are prolific seed producers. Seasons of adverse growth do not appear greatly to decrease the seed crop. The seed ripens mostly in June and July.

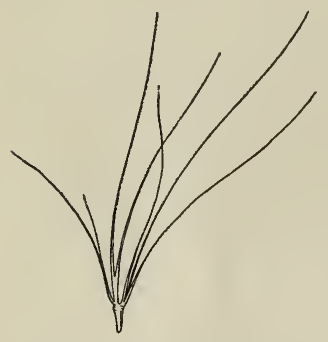

Fig. 72.-Squirrel-tail grass; joint with two spikelets, showing the glumes, the florets fallen (Sitanion hystrix).

\section{SQUIRREL-TAIL GRASSES (SITANION)}

A small group of native perennial bunch grasses, similar in appearance to squirrel-tail barley grass, but with coarser heads and more rigid awns. (Fig. 72). The heads disjoint in the same way as the barley grasses, and the joints are equally injurious to livestock. These grasses are mostly confined to dry, rocky, or semi-desert plains.

\section{GRAMA GRASS TRIBE (CHLORIDEAE)}

The grama grasses are the most valuable pasture species of this tribe. They occur sparingly, however, and are confined largely to the deserts and foothills of the South. The chloris grasses and Beckmann grass, which add to the forage crop, belong to this tribe. In the grama grass tribe the small spikelets are sessile and crowded along one side of an axis forming spikes; the spikes are spaced along an axis or clustered at the summit of the culm.

\section{Grama Grasses (Bouteloua)}

Eight kinds are found in the State, five being perennials and three annuals. Blue grama grass is the most abundant perennial. They are 
confined largely to the South. The grama grasses, while the most important pasture plants of the Southwest, are of secondary value in California because of their scattered occurrence.

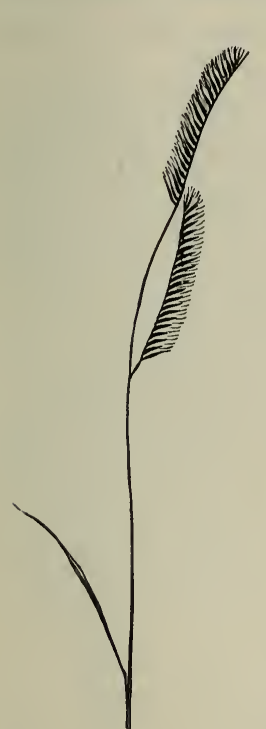

Fig. 73.-Blue grama grass (Bouteloua gracilis).

Description of Grama Grasses.-These are mostly low bunch grasses, with fine foliage and few (sometimes one) to several short spikes along a main axis. The spikelets bear one fertile (seed bearing) floret tipped with 3 minute awns, and one or two sterile florets reduced to a 3-awned rudimentary lemma.

1. Blue grama grass (Bouteloua gracilis), also called crow-foot grama grass, white grama grass, and "buffalo grass" (not true buffalo grass) is densely tufted, with a mass of fine loosely curly foliage at the base; slender culms $8-15$ in. (18-37 cm.) tall, and $1-3$ curved dense spikes $1-1 \frac{1}{2}$ in. (24-36 mm.) long. (Fig. 73).

Distribution and Habitat.-Blue grama grass grows in the plains and low mountains of the south, being most abundant in the San Bernardino Mts. It occupies well-drained soils but never occurs abundantly. In drought-endurance it ranks among the best.

Forage Value and Reproduction. - The herbage is eaten with unusual relish by stock whether green, as hay, or dry on the roots. The leafage cures on the ground unusually well and makes excellent winter feed. It is unfortunate that there is not more of this feed. The seed ripens late, usually not until August and September.

HAIRY GRAMA Grass (Bouteloua hirsuta) is similar to blue grama grass, but has bristly hairs on the glumes. SideoAT GRama GRASS (Bouteloua curtipendula) is the tallest of the gramas, and has numerous drooping spikes. (Fig. 74). Rothrock GRAMA GRASs (Bouteloua rothrockii) resembles blue grama grass but has $4-6$ smaller spikes. These are perennials of high palatability, but they occur so sparsely as to be of little value.

\section{CHLORIS GRASSES (CHLORIS)}

There is only one species, SILKY CHLORIS GRASS (Chloris virgata) in the State. This is a tufted annual

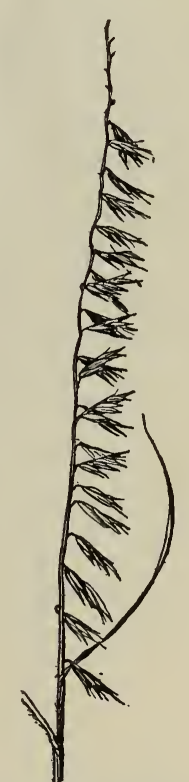

Fig. 74.-Side-oat grama grass (Bouteloua curtipendula). 
with spreading leafy culms, the upper sheaths swollen, and 6-12 pale feathery spikes, mostly $1 \frac{1}{2}-2$ in. (36-48 mm.) long, clustered at the

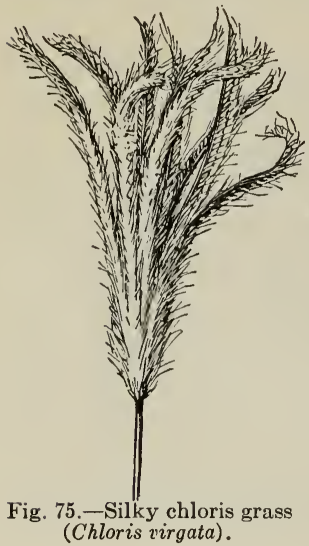
summit of the culm; spikelets small, the fertile and sterile lemmas silky, hairy and bearing slender awns. (Fig. 75).

Distribution and Habitat.-This is a plant of the plains and foothills of the south, being rather common near Riverside and along the Colorado River. The elevational range is from sea level to about 5,000 feet. It grows in dry soils but seldom forms the dominant vegetation.

Forage Value and Reproduction.-Late in the spring silky chloris grass becomes rather stemmy and is not eaten with the gusto that it is early in the season. Wherever it occurs in sufficient abundance, however, it is important as stock food.

Seed production is fairly large. It matures unevenly, most of the crop being cast in May and June.

\section{BECKMANN GRASS (BECKMANNIA)}

There is only one Beckmann grass (Beckmannia erucaeformis) in North America. It occurs somewhat commonly on certain California ranges. It is a rather stout lush annual, $1 \frac{1}{2}-3 \mathrm{ft}$. (45-90 cm.) tall, with flat blades and numerous short, stalked spikes in a narrow panicle; spikelets nearly circular, overlapping in the spike. (See genus Figure 29, page 17).

Distribution and Habitat.-Beckmann grass grows in wet meadows, moist coves, and along stream banks from sea level to an elevation of about 8,000 feet. It occurs from San Francisco Bay northward. The cover is often dense over small areas.

Forage Value and Reproduction.-Cattle and horses graze the entire plant rather closely the season through, taking it with more relish than most of the associated "water-grasses." It can hardly be classed as sheep feed because it grows on wet lands. They are known to relish the herbage, however, early in the season before it becomes coarse. A large viable seed crop is produced. 


\section{MESQUITE GRASS TRIBE (NAZIAE)}

There is but one genus of this small tribe in California; mesquite grasses (Hilaria) with two species. The tribe and genus are characterized by spikelets in clusters, the clusters falling entire from the axis. The mesquite grasses are perennials with thick hard rootstocks, narrow blades, and pale spikes. The spikelets are in 3's, one fertile in the middle with a staminate one on each side, with a tuft of hairs at the base of the cluster.

GALLETA GRASS (gah-yea-ta), botanically Hilaria rigida, has rigid white-felty culms with numerous stiff spreading blades; the foliage is also felty at first but much of it becomes smooth; spikes 2 to 4 in. (5-10 cm.) long. (Fig. 76).

Distribution and Habitat.-This is a plant of the plains and desert, growing among rocks and cactus in the Mojave and Colorado deserts, from sea level to an elevation of about 5,000 feet. Naturally the stand is sparse on the desert but in the better soils it is often quite dense.

Forage Value and Reproduction.-While galleta grass appears dry and stemmy it is highly palatable, especially to cattle and horses. It is unusually drought-enduring and readily "greens up" after a good rain. While the plants reproduce largely by means of the rootstocks the seed habits are generally good. The seed is disseminated in June.

TABOSA GRass (Hilaria jamesii) resembles galleta

Fig. 76.-Galleta grass (Hilaria rigida). grass but the culms are more slender and not felty, and the leaves are longer and softer; spikes mostly 2-3 in. (48-75 mm.) long. This, too, is a plant of the desert but it is less drought-enduring and much less common than galleta grass, hence occupies more protected habitats. In forage value and reproductive powers it is similar.

\section{SORGHUM TRIBE (ANDROPOGONEAE)}

This tribe is represented in California by only three genera, including four species. Johnson grass and plumed beard grass occur naturally on the range, being sometimes abundant. 
In the sorghum tribe the spikelets are in pairs, one perfect and sessile, the other sterile and pediceled, on the joints of a raceme. The racemes break up at maturity with the pair of spikelets attached.

JoHnson GRASs (Holcus halepensis), sometimes called Andropogon or Sorghum halepensis, is a robust perennial with vigorous rootstocks,

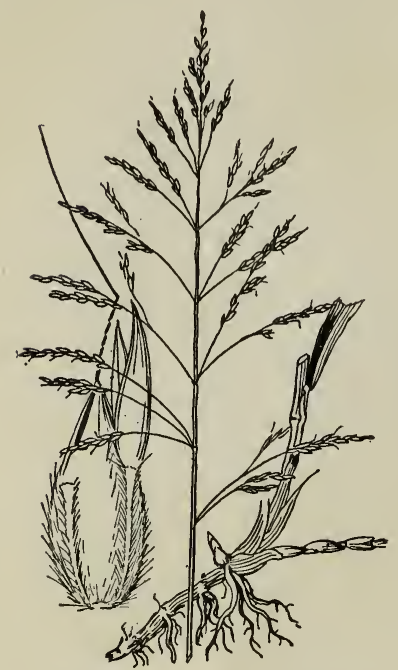

Fig. 77.-Johnson grass (Holcus halepensis). large blades, and an open panicle, the short racemes of $1-5$ joints borne at the ends of the branches. In the terminal joint there are two sterile spikelets, one on each side of the fertile one. (Fig. 77).

Distribution and Habitat.-This old world grass grows wild from Butte and Shasta counties southward along the coast, and to a less extent in certain other interior counties. It occupies well drained but not excessively dry sites and is unusually adaptable. Pure stands are often formed, for it is exceedingly aggressive. A long warm growing season and mild winters are essential to its permanence.

Forage Value and Reproduction.-Johnson grass probably has as many enemies as friends. The farmer who must fight it as a troublesome weed or replace it by introducing some other crop where it has long been grown for hay or pasture, declares it to be his worst enemy. Stockmen, on the other hand, who year after year graze their stock upon it or cut it repeatedly for hay, class it among the choicest of plants. Methods of eradicating it, however, and also of establishing a cover of Johnson grass are now fairly well understood. Stock relish Johnson grass when green as well as when made into hay. It is not a first-class permanent pasture plant, however, because (1) it becomes sod bound very readily and the yield decreases rapidly, and (2) the herbage occasionally produces toxic symptoms in stock, hydrocyanic acid being formed at certain stages of its growth. When fed as hay there are no poisonous effects. Reproduction is vigorous by means of rootstocks, yet a large amount of good seed is produced.

Plumed BEARD GRAsS (Andropogon saccharoides) is a perennial bunch grass, mostly $2-31 / 2 \mathrm{ft}$. (60-100 cm.) tall, with woolly nodes, fairly abundant foliage and a white plume-like head $2-4$ in. $(5-10 \mathrm{~cm}$.) long, consisting of the numerous feathery racemes; fertile spikelet awned. 
Distribution and Habitat.- This grass grows in the valleys and low hills from Santa Barbara to San Diego and eastward. It occupies a variety of soils but apparently prefers moderately moist clayey lands. In some localities it is fairly abundant.

Forage Value and Reproduction.--Until seed maturity the leafage is relished by pasture stock. Horses and cattle graze the herbage closely but sheep prefer less coarse feed. It seems to withstand grazing well and has the reputation of being a long-lived pasture plant. The earliest flower stalks appear in February. The seed mostly matures in April and May.

\section{SUMMARY}

\section{A Productive Range}

1. Profitable stockraising depends on good pasture and well-bred animals. Overgrazed ranges supply little feed of good quality. On run-down pastures the unpalatable and worthless plants have been left in possession.

2. There are two possibilities of improving the forage crop-(a) reseeding with cultivated or introduced forage plants, (b) revegetation (re-establishment of climax vegetation) by natural reseeding. Reseeding with cultivated plants is successful only on moist, fertile soils. Natural reseeding is practicable on all lands. By following a system of deferred and rotation grazing the valuable forage plants are allowed to set seed and re-establish themselves, yet no feed is wasted during the reseeding period.

3. In order to judge correctly the condition of the range and to apply the deferred and rotation grazing system it is necessary to know something of the growth requirements of the plants of the pasture.

4. Of all the families of plants of the range, the true grasses are the most valuable because of their palatability generally, their wholesomeness, their rather uniform yield, their good curing qualities, and their ability to withstand grazing and trampling better than most other plants.

5. About 125 of the different kinds of grasses growing in California are of importance as food for livestock. About 60 are highly valuable as forage, while the others afford more or less grazing. Ten or twelve with sharp-pointed seeds and rough awns or "beard" are injurious at maturity to grazing animals. 


\section{How to Recognize the Grasses}

6. It is easier to learn and to remember the numerous kinds of grasses if they are arranged according to their relationship.

7. To be able to place a given grass in its proper genus, in order to learn its name and find out what is known of its forage value, it is necessary to understand something of the structure of its flower head. This can be done by comparing the flowering parts of the grass in hand with the descriptions, keys and figures presented.

\section{Development of Range Forage}

8. The plants occupying any range are there because of natural selection. They grow and reproduce under the conditions prevailing there, because they are better adapted to these conditions than any others that have found their way to this range.

9. The type of vegetation is determined essentially by the character of the soil and of the climate. Lichens and mosses grow on rocks; annual plants on thin, rocky, or other inferior soils; long-lived perennials on deep, fertile lands.

10. If a range is overstocked, the animals devour the good plants so closely that they are killed or weakened, while the unpalatable or harmful plants, which the animals avoid, are left to seed and take possession. Even if a range is not badly overstocked the good plants will decrease in number if they are not allowed to set seed.

\section{The Range Grasses}

11. Fescues, blue grasses, and brome grasses (Festuceae). This tribe contains the largest number of important forage grasses. The brome grasses appear early in the development of range vegetation. Somewhat unpalatable annual bromes, the sharp-pointed seeds of three of them injurious at maturity to animals, are abundant on the lowland winter ranges. Perennial species are most abundant in the yellow pine belt. They give way under good management to blue grasses and fescues. The perennial fescues and blue grasses are excellent forage, but the melic grasses, also of this tribe, are only of moderate value as stock food.

12. Oat grasses (Aveneae). This tribe contains the well-known wild oats which affords excellent pasture on the foothills and valleys from late fall to early spring. The much smaller June grass, hair grasses, and other grasses of this tribe afford good but not abundant forage. 
13. Redtops, needle grasses, reed grasses, and timothies (Agrostideae). The needle grasses are among the best known and most important of the native species. They are all bunch grasses of high forage value, and are common on the summer and foothill ranges. They come in late in the re-establishment of perennial grasses of a range, and often constitute the climax cover. Cultivated and native timothy, the redtops, and reed grasses also afford pasture on summer ranges. Alkali dropseed which thrives where little other good feed is found, some of the muhlenbergias, and a few other grasses of this tribe are important on the poorer soils.

14. Wheat grasses and barley grasses (Hordeae). There are four important genera in this tribe, three of them-wheat grasses, rye grasses, and old world rye grasses-furnish palatable forage throughout the year. Barley grasses at maturity are injurious to stock because of the sharp-pointed, rough-awned seed, and should be grazed before the heads mature or in the autumn after the rains have softened the awns. They occur in the valleys and foothills. Wheat grasses are excellent forage but are abundant only in the extreme northern part of the State. The rye grasses are palatable to cattle and horses but are not abundant. The old world rye grasses are palatable but grow only in deep rich soils in the valley and foothill ranges.

15. Grama grasses (Chlorideae). Grama grasses, confined mostly to the deserts and foothills of the South, where they are of great value as pasture plants, grow thinly in this State, and contribute little to the forage crop.

16. Mesquite grasses (Nazieae). Galleta grass and tabosa grass, typical of the deserts and lower foothills, are highly palatable to cattle and horses.

17. Sorghums (Andropogoneae). Johnson grass, common in the South, is used as forage, though it is sometimes poisonous to stock, and is a bad weed in cultivated land. Plumed beard grass furnishes some forage in the southern part of California. 


\section{LIST OF PUBLICATIONS FOR SPECIAL REFERENCE}

Abrams, LeRoy.

1923. Flora of Pacific states. 1:103-255. figs. 218-607 (Grasses by Hitchcock). Stanford University Press, Stanford University, California.

Chase, Agnes.

1922. First book of grasses. 121 p. 94 figs. Macmillan Co., New York City.

Нттснсоск, A. S.

1920. Genera of grasses of the United States with special reference to the economic series. U. S. Dept. Agr. Bul. 772:1-307. 174 figs.

1914. Text-book of grasses, with especial reference to the grasses of the United States. 276 p. 63 figs. Macmillan Co., New York City.

JEPSON, Willis L.

1925. A manual of the flowering plants of California. (Grasses by Hitchcock, A. S., and Agnes Chase.) pp. 72-144. figs. 60-171. Associated Students' Store, University of California, Berkeley, California.

Sampson, Arthur W.

1924. Native American forage plants. 435 p. 199 figs. John Wiley \& Sons, Inc., New York City.

1923. Range and pasture management. 421 p. 130 figs. John Wiley \& Sons, Inc., New York City.

1917. Important range plants: their life history and forage value. U.S. Dept. Agr. Bul. 545:1-61. pl. 1-54.

1913. Reseeding of depleted grazing lands to cultivated forage plants. U. S. Dept. Agr. Bul. 4:1-34. pl. 1-8. figs. 1-4.

1913. Range improvement by deferred and rotation grazing. U. S. Dept. Agr. Bul. 34:1-16. pl. 1-5.

Sarvis, J. T.

1923. Effects of different systems and intensities of grazing upon the native vegetation at the Northern Great Plains Field Station. U. S. Department Bul. 1170:1-45. pl. 1-9. figs. 1-10. 
No.

253. Irrigation and Soil Conditions in the Sierra Nevada Foothills, California.

262. Citrus Diseases of Florida and Cuba Compared with those of California.

263. Size Grades for Ripe Olives.

268. Growing and Grafting Olive Seedlings.

273. Preliminary Report on Kearney Vineyard Experimental Drain, Fresno County, California.

276. The Pomegranate.

277. Sudan Grass.

278. Grain Sorghums.

279. Irrigation of Rice in California.

283. The Olive Insects of California.

294. Bean Culture in California.

304. A Study of the Effects of Freezes on Citrus in California.

310. Plum Pollination.

312. Mariout Barley.

813. Pruning Young Deciduous Fruit Trees.

319. Caprifigs and Caprification.

324. Storage of Perishable Fruit at Freezing Temperatures.

325. Rice Irrigation Measurements and Experiments in Sacramento Valley, 1914-1919.

328. Prune Growing in California.

331. Phylloxera-Resistant Stocks.

335. Cocoanut Meal as a Feed for Dairy Cows and Other Livestock.

339. The Relative Cost of Making Logs from Small and Large Timber.

340. Control of the Pocket Gopher in California.

343. Cheese Pests and Their Control.

344. Cold Storage as an Aid to the Marketing of Plums.

346. Almond Pollination.

347. The Control of Red Spiders in Deciduous Orchards.

348. Pruning Young Olive Trees.

349. A Study of Sidedraft and Tractor Hitches.

350. Agriculture in Cut-over Redwood Lands.

353. Bovine Infectious Abortion.

354. Results of Rice Experiments in 1922.

357. A Self-mixing Dusting Machine for Applying Dry Insecticides and Fungicides.

358. Black Measles, Water Berries, and Related Vine Troubles.

361. Preliminary Yield Tables for Second Growth Redwood.

362. Dust and the Tractor Engine.

363. The Pruning of Citrus Trees in California.

364. Fungicidal Dusts for the Control of Bunt.

365. Avocado Culture in California.

366. Turkish Tobacco Culture, Curing and Marketing.

367. Methods of Harvesting and Irrigation in Relation of Mouldy Walnuts.

368. Bacterial Decomposition of Olives dur ing Pickling.

369. Comparison of Woods for Butter Boxes.

370. Browning of Yellow Newtown Apples.

371. The Relative Cost of Yarding Small and Large Timber.

373. Pear Pollination.

374. A Survey of Orchard Practices in the Citrus Industry of Southern California.

375. Results of Rice Experiments at Cor tena, 1923

376. Sun-Drying and Dehydration of Walnuts.

377. The Cold Storage of Pears.

379. Walnut Culture in California.
No.

380. Growth of Eucalyptus in California Plantations.

382. Pumping for Drainage in the San Joaquin Valley, California.

385. Pollination of the Sweet Cherry.

386. Pruning Bearing Deciduous Fruit Trees.

387. Fig Smut.

388. The Principles and Practice of Sundrying Fruit.

389. Berseem or Egyptian Clover.

390. Harvesting and Packing Grapes in California.

391. Machines for Coating Seed Wheat with Copper Carbonate Dust.

392. Fruit Juice Concentrates.

393. Crop Sequences at Davis.

394. Cereal Hay Production in California. Feeding Trials with Cereal Hay.

395. Bark Diseases of Citrus Trees.

396. The Mat Bean (Phaseolus aconitifolius).

397. Manufacture of Roquefort Type Cheese from Goat's Milk.

398. Orchard Heating in California.

399. The Blackberry Mite, the Cause of Redberry Disease of the Himalaya Blackberry, and its Control.

400. The Utilization of Surplus Plums.

401. Cost of Work Horses on California Farms.

402. The Codling Moth in Walnuts.

404. The Dehydration of Prunes.

405. Citrus Culture in Central California

406. Stationary Spray Plants in California.

407. Yield, Stand and Volume Tables for White Fir in the California Pine Region.

408. Alternaria Rot of Lemons.

409. The Digestibility of Certain Fruit Byproducts as Determined for Ruminants.

410. Factors Affecting the Quality of Fresh Asparagus after it is Harvested.

411. Paradichlorobenzene as a Soil Fumigant.

412. A Study of the Relative Values of Certain Root Crops and Salmon Oil as Sources of Vitamin A for Poultry.

414. Planting and Thinning Distances for Deciduous Fruit Trees.

415. The Tractor on California Farms.

416. Culture of the Oriental Persimmon in California.

417. Poultry Feeding: Principles and Practice.

418. A Study of Various Rations for Finishing Range Calves as Baby Beeves.

419. Economic Aspects of the Cantaloupe Industry.

420. Rice and Rice By-products as Feeds for Fattening Swine.

421. Beef Cattle Feeding Trials, 1921-24.

422. Cost of Producing Almonds in California ; a Progress Report.

423. Apricots (Series on California Crops and Prices).

424. The Relation of Rate of Maturity to Egrg Production.

425. Apple Growing in California.

426. Apple Pollination Studies in California.

427. The Value of Orange Pulp for Milk Production.

428. The Relation of Maturity of California Plums to Shipping and Dessert Quality.

429. Economic Status of the Grape Industry 
No.

87. Alfalfa

117. The Selection and Cost of a Small Pumping Plant.

127. House Fumigation.

129. The Control of Citrus Insects.

136. Melilotus indica as a Green-Manure Crop for California.

144. Oidium or Powdery Mildew of the Vine.

157. Control of the Pear Scab.

164. Small Fruit Culture in California.

166. T'he County Farm Bureau.

170. Fertilizing California Soils for the 1918 Crop.

173. The Construction of the Wood-Hoop Silo.

178. The Packing of Apples in California.

179. Factors of Importance in Producing Milk of Low Bacterial Count.

202. County Organizations for Rural Fire Control.

203. Peat as a Manure Substitute.

209. The Function of the Farm Bureau.

212. Salvaging Rain-Damaged Prunes.

215. Feeding Dairy Cows in California.

217. Methods for Marketing Vegetables in California.

230. Testing Milk, Cream, and Skim Milk for Butterfat.

231. The Home Vineyard.

232. Harvesting and Handling California Cherries for Eastern Shipment.

234. Winter Injury to Young Walnut Trees during 1921-22.

238. The Apricot in California.

239. Harvesting and Handling Apricots and Plums for Eastern Shipment.

240. Harvesting and Handling Pears for Eastern Shipment.

241. Harvesting and Handling Peaches for Eastern Shipment.

243. Marmalade Juice and Jelly Juice from Citrus Fruits.

244. Central Wire Bracing for Fruit Trees.

245. Vine Pruning Systems.

248. Sorne Common Errors in Vine Pruning and Their Remedies.

249. Replacing Missing Vines.

250. Measurement of Irrigation Water on the Farm.

252. Supports for Vines.

253. Vineyard Plans.

254. The Use of Artificial Light to Increase Winter Egg Production.

255. Leguminous Plants as Organic Fertilizer in California Agriculture.

256. The Control of Wild Morning Glory.

257. The Small-Seeded Horse Bean.

258. Thinning Deciduous Fruits.
No.

259. Pear By-products.

261. Sewing Grain Sacks.

262. Cabbage Growing in California

263. Tomato Production in California.

264. Preliminary Essentials to Bovine Tuberculosis Control.

265. Plant Disease and Pest Control.

266. Analyzing the Citrus Orchard by Means of Simple Tree Records.

267. The Tendency of Tractors to Rise in Front: Causes and Remedies.

269. An Orchard Brush Burner.

270. A Farm Septic Tank.

272. California Farm Tenancy and Methods of Leasing.

273. Saving the Gophered Citrus Tree.

276. Home Canning.

277. Head, Cane, and Cordon Pruning of Vines.

278. Olive Pickling in Mediterranean Countries.

279. The Preparation and Refining of Olive Oil in Southern Europe.

281. The Results of a Survey to Determine the Cost of Producing Beef in California.

282. Prevention of Insect Attack on Stored Grain.

283. Fertilizing Citrus Trees in California. 284. The Almond in California.

285. Sweet Potato Production in California.

286. Milk Houses for California Dairies.

287. Potato Production in California.

288. Phylloxera Resistant Vineyards.

289. Oak Fungus in Orchard Trees.

290. The Tangier Pea.

291. Blackhead and Other Causes of Loss of Turkeys in California.

292. Alkali Soils.

293. The Basis of Grape Standardization.

294. Propagation of Deciduous Frnits.

295. The Growing and Handling of Head Lettuce in California.

296. Control of the California Ground Squirrel.

298. The Possibilities and Limitations of Coöperative Marketing.

300. Coccidiosis of Chickens.

301. Buckeye Poisoning of the Honey Bee. 302. The Sugar Beet in California.

303. A Promising Remedy for Black Measles of the Vine.

304. Drainage on the Farm.

305. Liming the Soil.

306. A General Purpose Soil Auger and its Use on the Farm.

307. American Foulbrood and its Control. 308. Cantaloupe Production in California. 309. Fruit Tree and Orchard Judging.

The publications listed above may be had by addressing

College of Agriculture,

University of California,

Berkeley, California. 